I -145 大腸癌肝転移の診断と治療一特に Angio-helical CT と術後補助化学療法の意義と有用 性について

\section{藤田保健衛生大学 消化器外科}

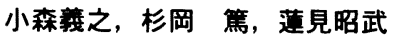

大腸癌肝転移切除例において術後早期の残肝再発も少 なくなく，その要因として微小な転移紧の見落とし・这 残が推察された. 今回は教室で行っているAngio-helical CT (AHCT)による微小病変の検索, および術後の補助 化学療法の意蕫と有用性について検討した. 本法施行後 に肝切除を施行した 27 病巣では, $5 \mathrm{~mm}$ 以下の 1 病獘以 外はすべて検出可能であった. 一方, 大腸癌肝転移切除 例においては, 転移程度, 転移個数, 多発例における最 小腫海径, 転移柴周辺の微小転移柴（類洞内浸澗, 門脈 内腫㾡栓など）が予後と密接に関与していた. さらに, 肝切除後の経門脈性化学療法（5FU持続投与）施行例 は, 背景因子に差のない非施行群に比し有意に良好な成 績であった．以上，大腸癌肝転移に対する治亦戦略とし て, 術前には従来の画像診断にAHCTを加えて正確手術 適応・術式を決定すること, また術後は肝転移の病態お よび病理組織学的所見に基づいて, 特に残肝における微 小転移果を標的とした補助化学療法を行っていくことが 肝要と考えられた.

I -146 大腸癌肝転移に対する外科治療および補 助療法の効果

\section{東京都立駒込病院外科}

高橋慶一、森 武生、安野正道

【目的】大腸癌肝転移切除の治療成績および切除後 の残肝・肝外再発治療について検討した。【方法】75 年から95年までの大腸癌肝転移切除143例を対象に、肝 切除法別（系統切除・部分切除）、TWの距離別の治 療成績および肝切後の 5 FUによる持続肝動注療法の効 果および肝外再発の治療成績について検討した。【結 果亡考察】肝切除法別の残肝無再発 5 年健存率は系統 切除 $(N=73) 35.7 \%$ 、部分切除 $(N=67) 27.8 \%$ で、 $T$ Wの距離別でも残肝再発率に有意差はなく、系統・部 分切除どちらでも、安全で容易に切除できる術式を選 択すれば良いと思われた。96例、67.1\%で高率に残肝 ・肝外再発を認めた。 5 年残肝無再発率は肝動注 $5 \mathrm{FU}$ 総投与量 $15 \mathrm{~g}$ 以上群 $(\mathrm{N}=45): 52.4 \% 、 15 \mathrm{~g}$ 未満群 $(\mathrm{N}$ $=30): 32.5 \%$ 、肝動注 $($ - $)$ 群 $(\mathrm{N}=65): 23.6 \%$ で、 $15 \mathrm{~g}$ 以上群で有意に $(P<0.05)$ 残肝再発予防効果を認めた。 肝外再発は肺転移が最も多く、5生率は肺切除群 $(\mathrm{N}=$ 16): $41.3 \%$ 、非切除群 $(\mathrm{N}=29)$ の $50 \%$ 生存期間は50 5 日で、有意に $(\mathrm{P}<0.0001)$ 肺転移切除群の予後が良好で、 切除可能例では積極的に切除すべきであると思われた。
I - 147 大腸癌血行性転移の特徴と治療成績 京都大学第一外科、同生体医療工学研究センター* 小野寺 久、前谷俊三 $*$ 、森本秀樹、山添善博 坂本忠弘、池内大介、河本和幸、韓 秀弦、今村正之

大腸癌の肺転移と肝転移の臨床的な特徵を比較し、 その治療成績を検討した。（方法）当科で入院手術を 行った大腸癌1086例を対象とした。肺転移と肝転移の 臨床的特徵を比較するため、各々の初発群の間でDise ase free interval(DFI)とCEA倍増時間を比較した。 治療成績は、病理学的因子、年齢、性別、手術方法、 転移個数、DFI、CEA倍増時間をあげ、Kaplan-Meier生 存曲線を描記して log-rank testで検定した。（結果） 肝転移群のCEA倍増時間は（120土170日）で、肺転移 群（250土307日）に比べて有意に $(p<0.05)$ 短かっ た。DFIのヒストグラムは肺転移群が二峰性で対数正 規分布、肝転移群が指数分布を示した。肺転移切除例 の5年生存率は $22.5 \%$ であり、予後にはDFIが有意であ った。肝切除例の 5 年生存率は $20.6 \%$ ありり、予後に 影響を及ぼす因子は肝転移個数とCEA倍増時間であっ た。 (考察) DFIとCEA倍増時間の解析より、大腸癌肝 転移は手術時に既に存在し、肺転移では手術操作によ る転移も示唆された。転移時期を考慮した術後管理は 重要であり、これはcost benefitを向上させ、再発 の早期発見により予後の改善をもたらす可能性がある。

I - 148 大腸癌脳転移巣手術例の臨床的検討 自治医科大学消化器一般外科 ${ }^{11}$,脳外科 ${ }^{2 i}$ 柏木宏 ${ }^{11}$, 小西文雄, 岡田真樹,黑川徳一 ${ }^{21}$,増沢紀男,金澤曉太郎 ${ }^{11}$

大腸癌脳転移17例の臨床経験を基に,脳外科手術の 意義を中心に検討した。対象及び方法：1978年から 1995 年の間に大腸癌脳転移例を 17 例経験した。脳転 移巣に対し手術を施行した10例,非手術例 7例を対象 に,脳転移巣に対する治療前後での神経症状の改善度, 転帰に関し検討した。また転帰は同時期に経験した乳 癌脳転移症例 10 例とも比較した。結果：大腸癌脳転 移例 17 例全体の脳転移治療後の生存期間は平均 5 力月 であり,乳癌脳転移例 10 例(平均 15 力月)より悪かった。 大腸癌術後脳転移手術施行例 8 例中, 6 例に他臓器再発 を認めていた。手術例全例に神経症状に対する治療効 果があり,脳外科手術後3力月から15力月間生存し,主要 な死因は局所再発2例,肝転移1例,肺転移3例,脳転移3 例,事故1例であった。脳外科手術非施行 7 例は,放射線 治療例 2 例中, 1 例は症状が軽度改善したが,1例は無効 で照射終了前に死亡した。非治療の 5 例は, 1 例は癌性 髄膜炎,3例は脳転移の増大で全例4力月以内に死亡した。 結論：大腸癌脳転移は発見時に多くが他臓器再発を 伴っていたが,激烈な脳転移症状の脳外科手術による 改善率は高く,また手術後は脳転移による死亡は少な かった。脳外科手術は有効な治療法と考えられた。 
I -149 大腸癌における肝・肺・脳転移切除の意 義について

金沢大学第 2 外科

西村元一、伏田幸夫、藤村隆、橋本哲夫、清水 康一、八木雅夫、米村豊、三輪晃一、宮崎逸夫 (目的)大腸癌の肝、肺転移に対しては、外科的切除 が積極的に行われ、良好な成績が報告されている。ま た脳転移についても根治性は無いものの症例によって は切除が有効であるとされている。今回、当科の大腸 癌症例における肝、肺および脳転移巣切除例を解析し、 切除の意義について検討を行った。（結果）1995年ま でに切除された肝転移症例は64例であり同時性が 33 例、 異時性が 31 例であった。また肺転移切除症例は15例で 14例が異時性であった。それぞれの予後は、肝転移切 除例が 3 年生存率 $52.2 \% 、 5$ 年生存率 $40.1 \%$ であり、肺転 移切除例は現在 4 年 6 力月を最長に 7 例が生存中であり、 3 年生存率が $44.1 \%$ でった。脳転移切除は現在までに 4 例に対して施行し、2例が術後 1 年末満に死亡したもの の、4例ともに神経症状は軽快しQOLの改善を認めた。 (まとめ) 大腸癌における肝、肺転移に対しては積極 的な切除により良好な予後が得られた。また脳転移に 対しては根治性が無くても単発性であり切除可能であ ればQOLの改善を考え手術も考虑すべきと考えられた。

I -150＼cjkstart直腸癌における側方郭清の適応と意義

\section{東京女子医科大学消化器外科学教室}

鈴木衛、吉田勝俊、井上雄志、安原清司、高崎健

過去 10 年間に切除した直腸癌 474 例のうち側方リンパ節 転移陽性は24例（5\%) で、Rs、Raでは 281例中 6 例 (2\%)、 Rbは 193例中18例(9\%)であった。腫崲の壁深達度mp以下に は側方転移例はみられず、ss(a1)は 145 例中 9 例(6\%)、se (a2) は170 例中12例(7\%)、si(ai) は21例中 3 例(14\%) で あった。Rs，Raで側方転移陽性 6例はすべてse(a2)以上で あったが、Rbではss(a1)にも側方転移陽性例がみられた。 根治度 $\mathrm{A}, \mathrm{B}$ が得られた側方転移陰性例( $\mathrm{n}=403)$ の 3 年、 5 年生存率は $80 \%$ 、62\%で、側方転移陽性例( $\mathrm{n}=18)$ ではそれ ぞれ $31 \% 、 6 \%$ \%っったまた、側方転移が 262 番単独陽 性例 $(\mathrm{n}=6)$ の 3 年、 5 年生存率は $66 \% 、 22 \%$ であったが、 272 番以遠転移陽性例 $(\mathrm{n}=5)$ では 3 生例、 5 生例はなかっ た。教室では側方郭清を適応とするのはRs、RaではSE' (A2 の)以上、RbではSS`(A1')以上の壁深達度症例としている。 側方郭清の範囲は 272 番リンパ節までを確実に郭清するこ ととしている。骨盤神経叢は骨盤神経叢への癌直接浸瀾例、 あるいは術中迅速診断で 262番の転移が証明された症例に は神経叢切除をしているが、傍直腸リンパ節あるいは上方 リンパ節のみの転移陽性例には骨盤神経叢を温存した側方 郭清を適応としている。
I -151

側方リンパ節転移陽性直腸癌に対する治療 的郭清法

横浜市立大学第二外科

池 秀之、坂下 武、菊池光伸、舛井秀宣、山口茂樹、 市川靖史、小金井一隆、江口和哉、大木繁男、㟫田 絋 【目的】側方転移陽性直腸癌に対する適切な郭清法につ いて検討した。【対象および方法】内腸骨血管の合併切 除を行わなかった30例（A群）と膀胱側㠬を開放し、内 腸骨血管の合併切除を行った5例（B群）を比較した。

【結果】A群の累積5年生存率は $41.4 \%$ 、再発率は $69.0 \%$ で、うち局所再発は $60 \%$ あっった。1例を除く平均局所 再発時期は9.8力月であった。部位別の成績は 262 転移陽 性例の累積5年生存率は $15.4 \%$ で、272の50\%、282の $55.6 \%$ と比べ、不良な傾向を示した。 B群の郭清側方 リンパ節個数は18.8個でA群の12.6個に比べ有意に多かっ た。観察期間は平均 13.2 力月であるが、現在まで再発を 認めていない。【結語】側方転移陽性例に対する膀胱側 腔を開放し内腸骨血管を合併切除する方法は局所再発を 減少させ、治療成績が向上すると思われる。

\section{I -152 大腸痋リンパ節転移巣における細胞接着分 子 E-カドヘリンの陽性発現}

筑波大学附属病院外科 ${ }^{1)}$ 、小川町国保中央病院外科 2 )、 筑波大学臨床医学系 3 )

金澤伸郎 ${ }^{1)}$ 、小田竜也 ${ }^{1)}$ 、軍司直人 ${ }^{2}$ )、野末睦 3 ) 川本徹 ${ }^{1)}$ 、近藤匡 ${ }^{1)}$ 、井坂直秀 ${ }^{1)}$ 、福永潔 ${ }^{1}$ 、稲川智 ${ }^{1)}$ 、 谷口英樹 ${ }^{1}$ )、高田泰次 ${ }^{3}$ )、足立信也 ${ }^{3)}$ 、湯沢賢治 ${ }^{3)}$ 、 啮谷進 ${ }^{3)}$ 、大塚雅昭 ${ }^{3)}$ 、垏 ${ }^{3)}$ 、深尾立 ${ }^{3}$ )

[目的] 大腸㴽のリンパ節転移に関与する分子機構 としての E-カドヘリン (E-CAD) の発現異常を解析す る。

[方法] 筑波大学附属病院で切除された大腸癌で、 リンパ節転移を伴った症例の内、高分化型、中分化型、 低分化型腺癌であった各 5 症例を選び、E-CAD の発 現、及び分布を抗ヒトE-CAD 抗体 (HECD-1)を用いた 免疫組織化学法 $(\mathrm{ABC}$ 法)により解析した。

[結果] E-CAD の発現は原発宩では陽性細胞と陰 性細胞が混在しており、リンバ節では転移している癌 細胞の大部分が陽性であった。

[考察] リンパ節転移した湙細胞のE-CADの発現に は、その組織型による差は認められず、リンパ節転移 の機構には組織型を越えた E-CADの発現との関連が 示唆された。 
I -153 周囲リンパ節転移が消失した上行結腸癌の 1 例

大津赤十字病院外科 ${ }^{1} 、$ 同放射線科

小切匡史 ${ }^{11} 、$ 安田誠一、下鄉 司、泉 冬樹、 井田 純、田村 淳、高本充章。馬場信雄、 小川博暉、坂梨四郎、芥田敬三 2

【症例】63歳、女性。2 型の上行結腸癌に対し右半 結腸切除術を施行したが、大動脈周囲リンパ節転移著 明であり、左腎静脈根部付近の大動脈後・大静脈後リ ンパ節は一部摘出不能であった。組織学的には中分化 腺癌、Ss、 $\mathrm{n}_{1} \cdot 4(+)$ であった。術後、残存リンパ節は 次第に増大し、術後 10 月目に高度の腰痛が出現した。 CTで転移リンパ節からの直接浸潤による第 3 腰椎の 骨破壊像を認め、CEAは101ng／mlに達した。そこで 転移リンパ節を中心に計50Gyの放射線治療を行った ところ、治療終了時には腰痛は消失、大動脈周囲リン パ節は著明に縮小し、CEAも11.8ng / $\mathrm{ml}$ と低下した。 放射線治療終了後 1 年 9 力月の現在、大動脈周囲リン 八゚節は消失し、CEA值も正常範囲内にある。

【考察】本症例は切除不能の大動脈周囲リンパ節転移 への放射線治療が著効する場合のあることを示してい る。放射線治療は進行再発大腸癌に対する集学的治療 の一翼を担うものと考えられる。

\section{I -154 \\ 結腸直腸癌局所再発に対する手術的切}

除の検討

桐生厚生総合病院外科

加藤健司、藤岡 進、伴野 仁、水野敬輔、相川 潔 岡田禎人、高橋吉仁、永田純一、広松 孝、菅原 元 $<$ 目的·方法 $>$ 結腸直腸癌の局所再発を、吻合部再発、 原発腫瘤周囲の局所の再発、リンパ節転移に分類して 手術成績を検討した。<結果>当科で過去 12 年間に切 除された結腸直腸癌の局所再発は 13 例であった。1) 吻合部再発は 4 例（S 1 例、 $\mathrm{R} \mathrm{a} 3$ 例）で、3 例は治 疮的に切除可能であった (24一-66 力月生存)。再発ま での期間の長い症例では、周囲㖶器への浸潤を考虑し た手術が必要である。2)局所の再発は7例であった(右 結腸 5 例、 $\mathrm{S} 1$ 例、R b 1 例)。5 年生存 3 例（1 例は 肝転移に対し肝切除併施）、3 例は腹膜播種により死 亡 (6-17 カ月) した。うち 1 例に小腸間膜リンパ節 転移を認めた。3）再発リンパ節を切除できたのは、2 例であった $(T, R$ b ) 。前者は右半切除後 2 年目に、 6)リンパ節転移（径 $10 \mathrm{~cm}$ ）を P D、吻合部切除で治疮 的に切除し 26 カ月生存、後者はA P R後のソケイリン パ節転移を 2 年後に郭清、24 力月生存している。 <結語〉結腸直腸癌の局所再発に対しては、積極的な 手術的切除が有効と思われた。

\section{I -155直腸癌術後局所再発症例の治寮方針 についての検討}

\section{田附興風会北野病院外科}

寺尾隆太、牧淳彦、高林有道

[目的］直腸癌術後局所再発では、局所のコントロー ルによって予後の改善が期待できる。自験例の治療成 績につき、文献的考察もふまえて報告する。[対象と 方法］直腸癌術後局所再発16症例の、初回補助療法、 再発形式、再発時の治療方法、合併症、予後、QOLK つき検討した。［結果］(1) 吻合部再発の4例は全例再 切除が可能で、局所の再々発はなかった。骨盤内再発 の12例のうち、1 例のみに骨盤内藏全摘を行ったが、 出血と感染に悩まされ、術後6力月で肺転移で死亡した。 5 例に局所化学療法を施行し、3 例で良好な腫瘍のコ ントロールとQOLの改善を得た。(2)初回に放射線療法 を行った 2 例のらち、骨盤内再発をきたした症例では、 治療に難渋したが、吻合部再発症例では良好な予後が 得られた。[結語］(1)吻合部再発に対しては、積極的 な再切除によって良好な予後が得られる。(2)骨盤内再 発では再切除は困難な事が多く、特に初回放射線治療 を受けている場合は重篤な合併症が予測される。(3)骨 瞥内再発に対しては、局所化学療法によって良好な腫 瘍のコントロールとQOLを得ることが出来る。

\section{I -156 大腸癌肝転移の予知と対策}

\section{東京女子医科大学消化器外科}

井上雄志、鈴木衛、吉田勝俊、高崎健

大腸癌の肝転移は予後を規定する最大因子であり、予 後向上には肝転移の予防、早期発見および治療が重要で ある。教室では漿膜下静脈侵襲陽性 $\operatorname{ssv}($ ( )および侵襲静 脈最大径 $400 \mu \mathrm{m}$ 以上の症例を肝転移高危険因子として 報告した。最大径 $400 \mu \mathrm{m}$ 以上の $\mathrm{ssv}(t)$ 症例は高危険群 として、血液中 CEA値を $1 \sim 2$ 力月毎、USは 3 力月毎に 行っている。予防的抗癌剂投与は5-FU系製剂の経口投与 に加え、5-FU持続動注療法を行っている。過去10年間で 62 例に肝切除を行い、転移の程度、転移時期、個数、腫 瘍径、選択術式および切離断端癌露出: $\mathrm{HE}( \pm)$ 別の残肝 再発率および 3 年生存率を比較した。 $\mathrm{HE}(+)$ の残肝再発 率がHE(-) と比較し有意に残肝再発率が高かったが、他 の因子間で差はなかった。単発31例で検討しても選択術 式別残肝再発率に差はなく、再発部位の 8 割が対側およ び多発再発であった。以上から大腸癌肝転移に対する選 択術式は HE(-)が得られる術式を選択すべきで、HE(-) が得られるなら系統的肝切除にこだわる必要はないと考 えている。しかし残肝再発部位は対側および多発再発が 多いこと、肝再切除10例中 7 例に肝再々発したことより、 残肝再発を防ぐ有効な補助療法の確立が急務之思われた。 
I - 157 大腸癌肝転移の診断におけるCT

during arterial portgraphy の有用性

東京女子医科大学第 2 外科、同放射線科 ${ }^{11}$

板橋道朗 浜野恭一 亀岡信悟 瀬下明良進藤廣成 呉兆礼 永田仁 勝田和信 遠田 譲 ${ }^{11}$

【目的】大腸癌肝転移の治療法, 術式の選択に際して は正確な転移巣局在診断と質的診断が必要である. 肝 転移の精密画像診断法としてへリカルCTを応用した CT during arterial portgraphy（以下CT-AP）を行い良好 な成績を得ているので従来の診断法と比較し報告する。 【対象および方法】対象は大腸癌924例のうち肝転移 症例114例である。CT-APの診断成績を従来のUSおよ びCTと比較しその有用性を検討した。CT-APはSMA にカテーテルを留置しヘリカルスキャンを行い撮影し た。【結果】CT-APでは転移巣は陰影欠損として描出 された. CT-AP, USおよびCTの肝転移巣個々の描出能 を検討するとCT-APでの平均検出数は $3.6 \pm 2.53$ 個, CTでは平均 $1.9 \pm 1.48$ 個, USで平均2.06 11.53 個であ った. CT-APの肝転移巣検出個数を従来のCTと比較 するとより多くの小さな転移巣が検出されていた（P $<0.05)$.【結語】 CT-APは大腸癌肝転移の診断にお いて最も鋭敏な検查法であり，治療法の選択および術 式の決定に非常に有用であると思われた。

\section{I - 158 全身PETによる大腸癌遠隔転移の診断}

東海大学第2外科 "', 山中湖クリニッ画像診断センター2” 安田聖栄 ${ }^{12}$, , 貞廣荘太郎 ${ }^{11}$, 向井正哉, 石田秀樹, 徳永信弘, 木村富彦, 鈴木俊之, 田島知郎, 三富利夫, 井出 満 ${ }^{2}$, 高木繁治, 正津晃

PET (positron emission tomography)は糖代謝の亢進 を画像表示する生化学的診断である。癌細胞では糖代 謝の穴進がありPETで検出できる。大腸癌の再発診断に 全身PETを適用し良い結果が得られているので報告する。 【対象】大腸癌術後に再発を疑い検査をした13症例中、 最終的に遠隔転移巣が確認された9例を対象とした。再 発部位は肝 6 例、肺 2 例、リンパ節 2 例、局所 1 例、腹膜 播種1例である。【結果】全例で転移巣が描出された。 $1 \mathrm{~cm}$ の肝転移はPETで診断できた。CEA高値でCTで異常を 指摘できなかった症例で肝転移が診断できた。肝、肺、 リンパ節転移をきたした症例では、PETのみで全病巣が 診断できた。S状結腸癌術後に腸閉塞をきたした症例で、 PETで局所再発が診断され手術が決定された。超音波と CTで2. $5 \mathrm{~cm}$ の肝転移が診断された症例で、PETで腹膜播 種も診断された。【まとめ】 $1 \mathrm{~cm}$ 以上の肝転移は診断で きた。また腹膜播種、局所再発も診断でき、肝、肺、 リンパ節転移は同時に確認できた。全身PETは大腸癌遠 隔転移の診断に適用できると考えられた。
I -159 大腸癌肝転移の危険因子と肝転移に対する 治療についての検討

東京医科歯科大学 第二外科

権田 剛, 吉永圭吾, 金仁燚, 井上 淳, 桶口哲郎, 井出明毅, 遠山芳樹, 西岡良薫, 山崎拓造, 北郷邦昭, 岩間毅夫, 三島好雄

【目的】1. 異時性肝転移をきたす危険因子, 2 . 比較的 成績のよい治療法, 3. 長期生存例の臨床病理学的特徵 【対象】1986.1 1995.12, 大腸癌手術症例 419 例中肝 転移症例 65 例 (16\%)【結果】1. 異時性肝転移症例之 非肝転移症例とでは, 深達度, $\mathrm{n}$ 因子, 術前 CEA 值に関 して有意差を認めた。2. H1 : 亜区域切除術以上施行症 例が平均生存期間の延長を認めたが, 生存率には有意差 を認めなかった。H2 : 肝切除術施行群が平均生存期間 の延長を認め,生存率に有意差を認めた $(\mathrm{p}<0.05)$ 。H3 : 動注群が無治療群より平均生存期間の延長を認めたが, 生存率に有意差を認めなかった。3. 長期 ( 3 年) 生存群 と短期生存群とを比較検討すると, $\mathrm{n}$ 因子, 肝切除施行 の有無に関して有意差を認めた。【結語】1. 異時性肝転 移をきたす危険因子：深達度・n因子が高度, 術前 CEA の高值。2.H1 - H2 症例の治療: 積極的な肝切除術, H3 症例 : 肝動注療法が有効である可能性。3. 長期生存 症例： $\mathrm{n}$ 因子が軽度, 肝切除術が施行できた症例。

I -160 131 I ラベルしたマウスモノクローナ ル抗体(MoAb)による大渴癌遠隔転移の腫䲴画像診断之 ミサイル燎法における有用性と問題点

県立愛知病院外科

坂本純一、加藤潤二、小島宏、安江満悟

[目的］ヨード131 にてラベルしたMoAbA33 による大 腸癌遠隔転移の腫瘍画像診断を行い、さらにラベル抗 体投与によるミサイル療法の抗腫瘍効果を検討した。

[症例之方法］大腸癌に特異的に反応するIgG2a のマ ウスMoAbA33 をい I で標識し、遠隔転移を有する大 腸癌22症例に対して投与を行い、腫瘍画像の描出、副 作用、腫瘍内集積の解析と抗腫瘍効果の検討を行った。

[結果］22例中20例において肝転移、肺転移、リンパ 節転移、腹膜幡種などの転移巣の腫瘍画像が描出され た。HAMAの産生は全症例において観察されたが、5例 において癌性腹水の消失、肺病変の縮小、リンパ節の 縮小、血清CEA 值の減少などが認められた。

[結語］MoAbA33 は腫癔の質的画像診断に有用と考え られた。またtargeting 療法に関する第一相および第 二相臨床試験では一部症例において転移巣の縮小、消 失が認められたがHAMA産生による抗原抗体反応が複数 回投与の効果を減殺することも明らかになり、抗体の humanizationが必要であることが示唆された。 
I -161肝動注化学療法を施行した切除不能大腸 癌肝転移症例の血清 CEA値と予後一血清 CEA値によっ て早期に予後の予測は可能か一

兵庫医科大学第 2 外科

野田雅史、柳 秀憲、池内浩基、荘司康嗣、

楠 正人、山村武平、宇都宮譲二

切除不能大腸癌肝転移症例に対し、5Fuによる肝動注 化学療法 (以下動注) 前後の CEA值の变動が予後予測 因子として有用であるかどうかを検討した。[対象と方 法]過去 10 年間に1力月以上動注を施行した 47 例を対象 とした。CEA (cut-off值3) は動注前と動注後2力月の値を 測定し減少率及び増加率を算定した。30\%以上減少した 群を $\mathrm{A}$ 群、30\%以下の減少及び増加した群をB群とし予 後との関係を検討した。[結果] A群18人 (CR 1、PR 10、 NC 7)、B群24人 (NC 4,PD 20) であり50\%生存期間はそ れぞれ14力月、7.25力月で A群で有意に生存期間の延長 を認めた。CTによる効果判定と比較した場合、動注後 2力月の時点でPRと判定できたものは11例中 3 例 (27.3 \%)のみであった。又、B群では全例2力月以降に $30 \%$ 以上 の減少を認めなかった。[結語] CEAは動注開始後早期 (2 カ月）のモ列版して有用であり、30\%以上CEA 值が減 少した症例では有意に生存期間の延長を認めた。治療 前後の CEA值の減少率が30\%以下であれば早期に他の 治療法を検討する必要があると思われる。

\section{I -162 大腸癌肝転移切除後の予防的残肝動注暴法 の有用性の検討}

\section{日鋼記念病院外科}

\section{辻 寧重、勝木良雄、安田隆義、西村昭男}

[目的］1991 年より大腸嵒肝転移切除後の残肝再発予 防を目的として、 $5 \mathrm{Fu}$ の間歇的大量動注（WHF=5Fu $\left.1000 \mathrm{mg} / \mathrm{m}^{2} 5 \mathrm{hrs} \mathrm{qw}\right)$ を施行しているが、極めて有用な治 療法であることが判明したので報告する。[方法]過去 16 年間の大晹煰肝転移 113 例のうち肝切除を施行したのは 30 例で、肝切除のみの 16 例 (A-1 群、 $\mathrm{H}_{1}: 12 、 \mathrm{H}_{2}: 4$ ) と肝切除後に残肝動注を加えた 14 例 (A-2 群、 $\mathrm{H}_{1}: 8$ 、 $\mathrm{H}_{2}: 4 、 \mathrm{H}_{3}: 2 ）$ の治療成綪を比較検討した。[結果] 累 積 1 年および 3 年生存率は、A-1 群の $64.6 \% 、 32.3 \%$ に対 しA-2 群では $100 \% 、 75.8 \%$ あり、A-2 群において有意 に成績が良好であった。累積 1 年および 3 年残肝再発率 は、A-1 群 45.3\%、69.6\%に対し、A-2 群では 1 年、3 年 ともに $8.3 \%$ あ゙り、A-2 群で有意に残肝再発が少なかっ た。残肝以外の迋隔転移は、A-1 群では肺 6 例、骨 2 例、 局所 3 例、肝門部リンパ節 2 例、脳 1 例であるのに対し、 A-2 群では現在まで肺 1 例、局所 1 例のみであった。[結 語] 大腸煰肝転移切除後の $5 \mathrm{Fu}$ の間歇的大量動注は、残 肝再発予防効果のみならず他の遠隔転移を制御している 可能性があり、極めて有用な治療法と考えられる。
I - 163切除困難な大腸癌遠隔転移病変に対する治 療法の有用性と限界

札幌医大第一外科、札幌月寒病院*

佐々木一晃、平田公一、山城一弘、和田好正、平池則雄、 高坂 一、柳内良之、池田慎一郎、山光 進*

【目的】切除困難な大腸癌遠隔転移病変に対する化学 療法の有用性と限界について検討を行った。【対象】 最近 5 年間の大腸癌遠隔転移 26 例で、病変は肝: 12 例、 肺:6例、リンパ節・腹膜ほか:8例であった。治療法は 全例中心静脈を用い、 $5-\mathrm{FU}: 320 \mathrm{mg} / \mathrm{m}^{2}$ を連日持続点滴 静注、CDDP: $3-7 \mathrm{mg} / \mathrm{m}^{2}$ を少量反復投与で 5 投 2 休と し、4 週間を 1 クールとした。【結果】平均治療期間 は1.5クールであった。CR:1例、PR:14例で、奏功率 は57.7\%であった。評価対象病変別の奏功率は肝臓で $58.3 \%$ 、肺 $83.3 \%$ 、リンパ節・腹膜などで $37.5 \%$ 之血 行性転移病巣に対して良好であった。1、3年累積生存 率は75.4\%、31.6\%。有効例で生存期間の延長傾向を 認めた。術前化学療法（IT）は 6 例で可能であった。 組織学的効果としてgrade 2 以上を 4 例に得た。切除 例の平均生存期間は有意に良好であった。【まとめ】 5-FU持続静注と CDDP少量反復投与の奏功率は $57.7 \%$ と良好で、とくに血行性転移症に有効であった。ITの 有用性が大腸癌症例においても認められた。

\section{I - 164 大腸疾遠隔転移紧(肝、肺、卵紧)切除の意義}

日本赤十字社医療センター消化器外科

遠藤 健、豊島 宏

1977年より 1995年の期間で当科で取り扱った大腸 癌切除例のうち肝、肺、卵単転移巣切除が行われた46 例を検討した。(I)肝転移巣切除22例：原発は、左側大 腸16例、右側結腸 6 例、進行度はDukes B 8例、Duke C 14 例で、単発切除 15 例、多発切除 7 例、同時切除 10 例、 異時切除12例であった。転移巣切除後16例 (73\%)洅発 し(残肝 15 例、肺 3 例)、うち 14 例が切除後 8 ケ月か 56 年、平均 2 年 3 ケ月で死亡している。再発なしの長期 生存例 ( 13 年、 12 年、 9 年、 7 年) を含めた 5 生率は $26 \%$ (5/19)で長期生存例はいずれも単発切除例であった。 (II)肺転移巣切除 20 例：原発は 1 例が上行結腸で、他の 19例は左側大腸であった。進行度はDukes B 9例、 Dukes C 11例て、、単発切除15例、多発切除 5 例、同時 切除 5 例、異時切除 15 例であった。転移単切除後16例 $(80 \%)$ ) 再発し(肺14例、肝 3 例、骨 3 例 ) うち15例が 1 年 2 ケ月か 58 年 平均 2 年 5 ケ月で死亡している。 5 生率は $12.5 \%(2 / 16)$ で、長期生存例 ( 8 年、6 年)は単 発切除例であった。( 而)卵巣転移巣切除 4 例: 原発は、右 側結腸、左側結腸各 2 例で、Dukes B の異時切除の 1 例は切除後 2 年再発の徵候はないが、Dukes C の同時 切除 3 例は、術後 7 ケ月から10ケ月で死亡した。 
I - 165 直腸痁肝転移術後, 一年後に尿管転移を きたし，切除しえた一例

三重大学医学部第二外科

井上登仁, 松本好市, 山本隆行, 東崇明, 三木誓雄 本泉誠

転移性尿管腫瘍は本邦で 61 例が報告されている のみで比較的まれな疾患である。今回我々は直腸癌 術後, 各々単独に, 肝転移, 尿管転移をきたし, い ずれも切除しえた一例を経験したので若干の文献的 考察を加えて報告する。

患者は67歳男性。平成 5 年 7 月直腸癌 $(\mathrm{Ra})$ にて低 位前方切除施行。Ho, 0 , , So, No, StageI。well diffarentiated adenocarcinoma,pm,lyo,vo,no, BorrIIであった。平成6年6月肝S6,S7領域に計 3 個 腫瘍を認め, 肝右葉切除を施行。組織はいずれも well diffarentiated adenocarcinomaで, 直腸 癌肝転移と, 診断された。平成 7 年 4 月, 左水腎症 および，左尿管腫瘍を指摘され，左腎，尿管全摘術 を施行した。尿管腫瘍は約 $2 \mathrm{~cm}$ で非乳頭状広基性腫 瘍であった。組織はadenocarcinomaで直腸癌原 発転移性尿管腫瘍と診断された。現在, 再発徵候な く, 外来で経過観察中である。

\section{I -166 甲状腺転移を来した直腸癌の2症例}

\section{大阪逓信病院外科、同耳鼻咽喉科 ${ }^{1 !}$ 、同第二臨床 \\ 検査科 ${ }^{2)}$ 、大阪府立成人病センター 外科 $^{31}$ \\ 堌田慎三、丸山博英、丸橋繁、徳永膦、漟口修司、}

松井成生、矢野浩司、立石秀郎、衣田誠克、弥生恵司、

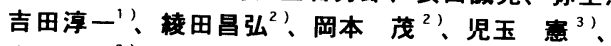
小山博記 ${ }^{3}$ ，土井 ${ }^{3}$ ! 岡村 純

大腸癌甲状腺転移は臨床的に診断治療されることは 極めて稀である。今回我々は、甲状腺転移を来した直 腸癌2症例を経験したので報告する。【症例 1】38歳 女性。1986年、直腸癌(Rb;circ, Borr2)で、腹会陰式直腸 切断術(D3)施行。高分化型腺癌、stage III a; Po, Ho, no, ai(子 宮), M(-), ly2,v1、根治度A。1990年、濡慢性甲状腺腫 · 咳嗽・高CEA血症 $(210 \mathrm{ng} / \mathrm{ml})$ が出現。精査で直腸癌の甲 状腺 - 肺( $\mathrm{rt} . \mathrm{S} 1$ )転移と診断し、同年12月、甲状腺全摘 . 右䅡部リンパ 節郭清(RND)、右肺上葉切除術施行。病理 所見で直腸癌の甲状腺 - 肺転移と確定診断。術後5 月 目、肝転移・腹膜播種で死亡した。【症例 2】橋本病 の既往のある73歳男性。1994年、直腸癌(Rs;circ,Borr2) · 転移性肝腫瘍で、低位前方切除(D2) · 肝S8部分切除術 を施行。高分化型腺癌, stage IV;Po, H1, n1,s s, M(-), ly 1,v 1 、 根治度B。1995年9月、CEA上昇 $(50.4 \mathrm{ng} / \mathrm{ml}) \cdot$ 嗄声が出 現。精査で甲状腺癌と診断し、11月、甲状腺全摘・右 RND施行。病理所見で、直腸癌の甲状腺・頝部リンパ節 転移と橋本病・悪性版腫の合併と確定診断。1996年3 月現在、健在である。
I -167 下部直腸癌低位前方切除術における側 方郭清の有無からみたSoilingの検郡

日本大学第 1 外科

五十風諴悟、富田凉一、黒須康彦、阿部義蔵、

滝沢秀博、柴田冒彦、小出浩史

目的:下部直腸癌低位前方切除術 (LAR)後症例におけ る側方郭清からみたsoilingの有無を、電気生理学的に 神経因子を中心に分析した。対象: 術後2年以上経過し たLAR症例32例である。このうちsoilingを $34.4 \%(11 /$ 32)に認め、これらは側方郭清 (+)症例が10例と多くを占 めた。そこでLAR症例を侧方郭清 (+)症例 16 例 (A 群) と侧 方郭清 (-) 症例 16例 (B群)の $2 つ に$ 分類した。対照 (C群) には排便異常の無い体表手術症例16例を用いた。方法 :1)陰部神経とS2-4脊咆神経伝導時間测定。2)肛門管上 部粘膜電流感覚閾值测定。結論: 1) soil ing 症例 11 例中 側方郭清 (+)症例が 10 例と $90.9 \%$ を占めた。 2) 側方郭清 $(+)$ 症例は陰部神経と S2-4春酭神経損侮を明らかに強く 琶めた。3) 側方郭清 $(+)$ 症例は肛門管上部粘膜電流感覚 閾值が明らかに高かった。以上のことより、側方郭清が 低位前方切除術に行われれば、恥骨直腸箭、外肛門括約 筋、肛門管感覚の神経系が損偒を受けSoilingの原因と なることが判明した。

I -168 体型が肛門機能へ及ぼす影響について

とくに体重・身長・体格との関係について

\section{福岡高野病院}

辻 順行、高野正博、黒水丈次、豊原敏光、嘉村好峰. （目的）外来にて診察を行うと、肥満者に肛門の収 縮が強い症例を多く認める。そこで体格と肛門機能の 関係を解明すへく、正常例に機能検査を行い検討した。

（対象及び方法）1995年1月から12月までに当院外来 を受診した非直腸肛門症例で、20～60歳代の体重60〜 $79 \mathrm{Kg}$ 、身長160〜 179cmの男性115例を対象とし、115 例を身長を一定とした上で5 $\mathrm{Kg}$ 体重別に4グループに、 次に体重を一定とした上で $5 \mathrm{~cm}$ 身長別に4グループに、 最後に肥満度（体格）を一定とした上で $5 \mathrm{~cm}$ 身長別に4 グループにそれぞれ分け、肛門機能検査（静止圧、随 意圧、肛門管長）を行い体型が及ぼす影響を分析した。

(結果) 静止圧 : 体重から分類したグループと体格 から分析したグループでは有意な差を認めた。しかし、 身長から分類したグループには有意な差を認めなかっ た。随意圧＆肛門管長 : 体重、身長、体格のいずれの 分類したグループにおいても有意な差を認めなかった。 （結語）肛門機能の中では静止圧が体格の中の体重 と最も強く関係した。よって軽体重症例の直腸肛門手 術に際しては、術式に注意すべきであると考えられた。 
I -169

生体内分解性消化管吻合リング使用症例 の臨床的検討

小郡第一総合病院外科

品川裕治、水田英司、中村真之、原田菊夫

消化管吻合 11 例に扔いて圧挫式消化管吻合器の一 つ生体内分解性消化管吻合リング (以下 B A R)の使用 経験を得たので、その結果の臨床的検討を報告する。

[対象および結果］結腸癌 6 例、膀腅癌 2 例、胃癌 横行結腸浸潤 1 例、直腸㾔膀脱浸潤 1 例に使用し、吻 合部位は、結腸結腸 4 例、結腸直腸 3 例、小腸結腸 1 例、小腸小腸； 3 例であった。腹腔鏡補助下結腸手術 2 例に使用したが、吻合部を体外で行えばその操作は 非常に簡便であった。回腸導管作成時の回腸回腸吻合 3例に使用したが、リングが小断片となり排泄される ためか排泄までの期間は他の吻合部位と差は無かっ た。拡大 $\mathrm{S}$ 状結腸切除後の結腸直腸吻合の際には操作 部位がやや深くなるが、口側の晹管内にまずBARの一 方を挿入固定後に肛門側の腸管を挿入固定すれば、吻 合部位を直視でき操作は容易であった。術後の腹部㰣 満感を 2 例に認めたが、リング排泄後には症状も消失 した。他に合併症は認めなかった。

[まとめ］B A Rによる消化管吻合は、簡便、迅速 かつ安全であり、有用な手技であると思われた。

I -170 新しく工夫した皮肩弁（Skin Flap）作成 法による結腸库について

\section{猲協医科大学第二外科}

門監 淳、九里喷夫、佐久間敦、田鳥 充、 冨田利夫、大盛芳路、門馬公経、小暮洋暉 [目的] 現在の回腸度あるいは結腸搷の作成法は腸 管断端を反転する方法が一股的である。この方法は粘 膜と皮虚の接合部が通常の皮肯レべルになる。従って、 基本的に、装具の粘着削がその厚みの分だけ粘謨何に かぶさるようになる不都合な面を有している。そこで、 この久点を補うために、皮虚面を通常のレベルよりも 挙上させて、粘膜皮虚接合部を皮膚レベルよりも高く する方法を工夫したので報告する。

[方法と対象] 結渴馾の处理は通常の方法と同棣であ る。皮虚切開は術前のマーキンクの位直を中心に直径 約 $3 \mathrm{~cm}$ の円を描き、これを 8 等分する。中心よりこ の等分点に直線を描きこれに沿って皮鹿切開を行なう。 すると 8 つの皮有弁が作成される。その後通常の結腸 瘦の様に的 $2 \mathrm{~cm}$ 程度腸管を突出させ、粘䐜面は反転 させずにそのままこの皮虑弁の先端を粘膜に綘合する。 この方法を 7 例に行なった。

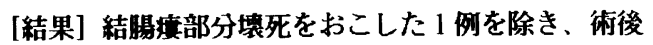
3 13力月の経遇は良好である。
I -171 青年期男性の直腸脱に対して経肛門的 直腸 $S$ 状結腸切除術(Altemeier法)を施行した 1 症例 広島大学第 1 外科", 広島大学総合診療部 ${ }^{21}$ 佐々木茂"，児玉節", 竹末芳生 ${ }^{1}$, 村上義昭 ${ }^{12}$, 今村祐司 ${ }^{1}$, 津村裕昭 ${ }^{1}$, 新原主計", 立本直邦", 赤木真治", 横山隆 ${ }^{2}$, 松浦雄一郎"

【症例】 26 歳男性. 16歳時より排便後直腸脱出を認 めおり当科入院となった．入院時腹圧をかけると直 腸全層の脱出を認めた。手術は全身麻酔下にP rone Jackknife Positionにて行った. 直腸を银転させ歯状線 より約 $2 \mathrm{~cm}$ の部位で全周性に直腸全層に切開を加え， 内筒を形成する直腸を中枢側へ向けて剥離を進め, 腹膜を切開し腹腔へつなげた.S状結腸間膜を処理し， 用手的に腸管の緊張を確かめ, 吻合の際に過度の張 力がかからない部位にてS状結腸を切離した，腹膜縫 合を施した後, 吻合は3-0Dexonを使用し 1 層全層に て結節縫合とした，術翌日軽度の肛門部痛のみで歩 行可能であった。術後2力月再発はない.【考察】若 年男性の直腸脱は非常に稀である. Ripsteinの手術で 術後性機能障害の報告があり, 本術式を選択した. またpoor risk症例の患者に於いても手術侵襲が少ない 本術式は有用な術式と考える。

\section{$\mathrm{I}-172$ 腸管膀胱瘦の 3 例}

\author{
高知医科大学第 1 外科 \\ 杉本健樹，高野 篤，秋森豊一，松浦喜美夫， \\ 金子 昭，小林道也，別府 敬，氏原孝司， \\ 柏井英助，荒木京二郎，緒方卓郎
}

腸管膀胱瘦は、種々の疾患に合併する稀な合併症で あるが、本邦でも左側結腸悡室症やクローン病の増加 に伴い、その報告が增えつつある。われわれは、クロ ーン病で 1 例、結腸悡室炎で 2 例の腸管膀胱渡を経験 したので報告する。症例 1 は19歳男性で、3 年間のク ローン病の既往の後に回腸膀胱瘦を発症し、保存的治 療を 2 年間行い、尿路感染症の反復のため手術を行っ た。症例 2 は60歳男性で、排尿時痛と気尿のため近医 を受診し S 状結腸膀胱渡と診断され、半年後に当科に 入院した。症例 3 は79歳男性で、排尿・排便困難で発 症し近医で直腸腫瘤を指摘され当科に紹介入院し、高 熱と膿尿の後、気尿を認め直腸 ( $\mathrm{S}$ 状結腸部) 膀胱漠 と診断された。4ヶ月間経過観察したが、気尿による 不快感から手術を希望し再入院となった。術前、注腸 造影で 3 例全てに造影剤の腸管外漏出を認め、C T . 胱鏡検査で膀脱の隆起様病変を認め腸管膀胱隻と診断 した。手術では、 3 例ともに病変腸管と瘦孔の可及的 切除を行い、膀胱は切除せず久損した筋層の縫合のみ としたが、術後は良好に経過している。 
I -173 結腸間膜デスモイドの 1 例

北里研究所メディカルセンター病院 外科 ${ }^{11}$ 同放射 線科 ${ }^{21}$ 同病理 ${ }^{31}$

西 八嗣 ${ }^{11}$, 板橋浩一, 立石 晋, 佐藤幸一,

田所文彦, 八十川要平, 田所克己 ${ }^{2)}$, 本告 匡 ${ }^{3)}$

結腸間膜に発生した、稀な疾患である腹胫内デスモ イドの 1 例を経験したので報告する。

症例は51歳女性。平成 7 年 7 月はじめより心窩部痛 が出現し、7月17日当院外来を受診した。触診にて腹 部に腫瘤を触知したため、8月 2 日精查目的のため入 院となった。腹部超音波検査では直径約 $10 \mathrm{~cm}$ 大の hypoechoic mass として認められ、 $\mathrm{C} \mathrm{T}$ 検査では enhance される内部が均一の充実性の腫瘤として認め られた。腹部血管造影では腫瘤は上腸間膜動脈を栄養 血管として腸間膜動脈の伸展および新生血管の増生を 認めた。以上より間葉系の腫瘍を強く疑った。9月20 日手術を施行し、腫瘍を含めて横行結腸切除および小 腸間膜の部分切除を行った。摘出標本は $9.5 \times 9 \times$ $8.5 \mathrm{~cm}$ 大の球状の腫瘤で、割面は白色調で充実性であ った。組織学的には線維芽細胞様の紡鍾形細胞の束状 、波状の増殖がみられ、間質は線維化、硝子化を呈し 全体に血管が豊富であった。細胞異型は之しく、多形 性もなく、核分裂像も殆どみられず、デスモイドと診 断された。術後 4 力月現在再発の兆候はない。

I - 174 肛門周囲パジェット病の1例

市立甲府病院外科

巾 芳昭、加藤邦隆、松下明正、青木孝學、村松昭、 小田島弘明

肛門周囲パジェット病は極めて稀な疾患であるが、 癌の合併も多く前癌病変としその治療法の選択は慎重 に施行すべき疾患である。今回、我々は81歳男性に発 生し、根治手術を施行し得た肛門周囲パジェット病の1 例を経験したので報告する。症例；81歳、男性。主訴; 肛門狭窄。現病歴; 平成7年7月頃より肛門の狭窄症状 が出現し、同年8月近医にて内肛門括約筋の切断と内庤 核の切除術を施行され切除標本より、肛門周囲パジエ ット病と診断され、治療目的に当科を紹介された。入 院時現症及び経過; 肛門周井に比較的境界明瞭、不整 型、 $50 \mathrm{~mm}$ 大の脱色素斑を認めた。他臓器に異常なく 鼠径リンパ節の腫大も認めなかった。肛門周囲パジェ ット病は、広範囲局所切除後の再発例や下床癌の合併 例が多いこと、直腸、肛門部の再発は発見が遅れるこ と等を考慮し、本例では根治性を優先し腹会陰式直腸 切断術を施行した。切除断端に於ける病巣の残存はな く、下床癌の存在も認めなかった。術後4力月の現在、 無再発生存中である。今後は病変の浸潤範囲、再発様 式、術後のQOLを考慮した手術術式、集学的治療法の 検討が必要と思われた。

\section{I - 175 大腸癌の遡及的検討一自然史について}

\section{国立大阪病院 外科}

竹政伊知朗 柳生俊夫 吉川宣輝 辛 栄成 三嶋秀行 蓮池康徳 小林研二小林哲郎

大腸癌の自然史を明らかにする目的で、当院におい て切除された大腸癌のうち、注腸X線検査によって遡 及的に病変の推移を検討できた10症例を報告する。 症例 $1 \mathrm{~S} 17 \mathrm{~mm}$ 3型 ss, 6 年5月前 $7 \mathrm{~mm} \mathrm{lla}$ 症例2 S $28 \mathrm{~mm}$ 2型 se, 1年3月前 $11 \mathrm{~mm} \| \mathrm{a}+11 \mathrm{c}$ 症例 $3 \mathrm{Rb} 32 \mathrm{~mm} 2$ 型 $\mathrm{pm}, 5$ 年2月前 $10 \mathrm{~mm} \mathrm{llc}$ 症例4 T $20 \mathrm{~mm}$ 3型 ss, 7月前 $16 \mathrm{~mm}$ 2型 症例 $5 \mathrm{Ra} 27 \mathrm{~mm} 1$ 型 $\mathrm{sm}, 7$ 月前 $20 \mathrm{~mm}$ lla 症例6 A $58 \mathrm{~mm}$ 2型 se, 11月前 $34 \mathrm{~mm}$ 2型 症例 $7 \mathrm{~S} 18 \mathrm{~mm}$ 2型 $\mathrm{pm}, 4$ 年5月前 $6 \mathrm{~mm}$ is 症例 $8 \mathrm{~S} 20 \mathrm{~mm}$ 2型 $\mathrm{pm}, 4$ 月前 $17 \mathrm{~mm}$ \|la さらに 2年4月前 $11 \mathrm{~mm}$ is 症例9 $\mathrm{T} 74 \mathrm{~mm}$ 2型 ss, 3 月前 $57 \mathrm{~mm}$ 2型 症例10 T 15mm 2型 $\mathrm{mp}, 2$ 年前 $10 \mathrm{~mm} \mathrm{lla+llc}$ 以上の症例より、肉眼的な形態の変化と、doubling time を算出する事で、大腸癌の自然史について検討 した。

Iー176早期経山攝取を行った大腸癌症例の検討

国立がんセンタ一東病院外科

杉藤正典、小野正人、新井竜大、谷山新次、

白井芳則、清家和裕、岡本健、竜崇正

大腸癌術後の胃管抜去、食事開始の時期の決定は慣 例的に行われてきた。我々は早期に食事を開始し検討 した。大腸癌切除例で手術時間 5 時間、出血量 $1000 \mathrm{ml}$ までの症例 20 例を対象に、これ以前の 20 例を対照群と した。方法は術後1目に胃管抜去、水分を許可。2日目 から食事開始し、1 日毎に全䋆まで上げた。対象20例 のうち繾合不全 1、MRSA腸炎1、強い腹痛 1 の計 3 例 $15 \%$ で予定を中止し、問題なく完遂できたものは14例70\% であった。対照群でも繾合不全 1 例、強い腹痛・腹満 が 2 例みられ同程度の合併症であった。術後人院期間 は対象 20 例全体で 19.5 日と対照群の 22.2 日より約 3 日 短く、問題なっかた症例 14 例では16.2日と6 日間早か った。排ガス・排便の時期は対照群より 1 日早く、全 䐖半分の食事掑取俚11.2日と対照群の16.4日より5日 早かった。まとめ (1) 20 例の予備試験の結果、予定を 完遂できた症例では人院期間の短縮等が認められた。 (2)合併症の頻度も従来法と変わりなく、予定を中止し た症例を含めても人院期間の延長は見られなかった。 (3)今後無作為割付による比較試験を予定している。 
済生会滋賀県病院外科

\section{國嶋畫、西田智樹、東田武、西植隆}

米山千爱、渡辺信介

肉眼的にびまん性に浸潤傾向を示すものは,胃癌と異 なり,全大腸癌中 $1 \%$ 未渵にすぎない.急性腹症を呈した

自臨 2例に文献的考察を加えて報告する。

症例 $1: 36$ 歳男性.腹部全体に疼痛の增強を認め,救急 受診した.激しい疼と腹膜刺激症状を認めたため, 沉 発性腹膜炎の診断下,紫急手術を行った.術中所見は,腸 管が広籁囲にわたり鉛管状硬化を呈し,腸間膜リンパ節 腫大も著明であった.病因特定し得ず,閉塞部位の $S$ 状結 腸のみ切除した.病理結果で, 印環細胞癌で断端陽性で あったか，再手術の適応無く補助化学療法を行った。術 後 5力月目に癌死した.症例 $2: 43$ 歳男性.下腹部痛の增強 を認め,救急受診した.消化管穿孔による汎発性腹膜炎 の診断下, 督急手術を行った。術中所見は, $S$ 状結腸癌穿 孔, SE, P 3 HON2で, S 状結腸切除術を行った.術後補助化学 療法を行ったが,8か月目に癌死した。

自験例は.病理組織はsig,mucであったが文献的には $15 \%$ 程度に高・中分化腺癌も認められている。いずれの 症例も高度なリンパ管浸潤を伴い、またCEAの上昇も認 めた。

I - 178 姑息的切除と化学㞠法で延命効果をみた 若年者び漫浸潤大腸癌癌性腹膜炎の 1 例

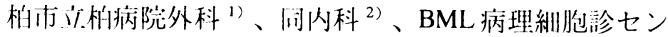
夕-3)

松本川洋 ${ }^{1)}$ 、延澤進、佐藤彰治、酒井英樹 ${ }^{2)}$ 、大林日 组雄、田中鼠 ${ }^{3)}$

若作者び漫浸潤大腸福は極めてまれだが、命[回 $\mathrm{S}$ 状結 腸粘液癌による全周狭窄と多量の腹水を伴う癌性腹膜炎 を呈した若年男性の初発症例に対して、化学療法の後に、 姑息的切除術を施行し、初診後 1 年以上の延命效果を見、 かつ良好な quality of life を保っているので、若Fの文献 的考察を㞦えて報告する。症例は 25 歳の土木作業員で、 7 年 3 月 6 日、血便、腹満感、胅周国痛を主訴にして当 院内科を初颜し人院。超音波検查で多量の腹水が見られ、 大網の不整な板状肥厚と腹水巾の浮き草様の多数の結節 を認め癌怆牌膜炎が疑われた。朋転移や大動脈周目のリ ンパ節の腫大は見られなかった。注腸検査で $\mathrm{S}$ 状結腸に $9 \mathrm{~cm}$ にわたる不整な狄政像を示し、腹水緗胞診はクラス Vで、mucinous carcinoma 由来と考えられた。5FU、ロ イコボリン、CDDP の化学療法を 2 クール施行し、腹水 の著明な減少を認めたが、腸管の㹨窟壮状はとれず、7 月 3 H、S 状結腸切除術を施行。術後経過は良好で、8 月 1 日退院し、その後化学療法目的で数回短期入院をし たが、現任経门摄取も问能で化事にも復帰している。

\section{山陰労災病院外科}

竹林正孝, 斎藤博昭, 太田道雄, 若月俊郎, 岡本恒之、鎌迫 陽, 谷田 理, 結腸癌の中でも、扁平上皮癌は極めてまれである。 われわれは、S 状結腸に原発した扁平上皮癌の 1 例を 経験したので報告する。

[症例］67歳、男性。[主訴] 下腹部痛、高度便秘。 [現病歴] 平成 7 年 7 月上記主訴にて、前医を受診。 大腸精查を施行され、当科紹介となり、平成 7 年 9 月 入院となる。］入院経過］術前検查では、転移性では なく、原発性の S 状結腸扁平上皮癌と診断された。

[手術所見］S 状結腸に約 $9 \mathrm{~cm}$ の腫瘍を認め、後腹膜 ・左尿管に広範に直接浸潤していた。さらに後腹膜腔 から大腰筋部にかけて膿瘍を形成していた。腫瘍部を 切除し、腸管の肛門側は閉鎖し、口側は人工肛門を造 設した。膿瘍はドレナージを施行した。［病理組織所 見] 低分化から中分化型の扁平上皮癌で、INF $\gamma, s i$, ly(1), v(2), ow (-), aw(-), ew(t), n(-)，であった。

[臨床経過］術後53日目に、後腹膜膿瘍による敗血症 で死亡した。 [考察] 結腸癌のなかで扁平上皮癌は極 めてまれであり、その発生頻度は結腸癌の0,025\% $0,1 \%$ とされている。文献的考察を加え報告する。

\section{I -180胃結腸瘻を合併した結腸癌の 2 例}

\section{新下·里病院外科}

高村勇貴、高地 耕、金子克彦、斎藤真文、上出進久、 前浦義市、松永征一

症例 1 は65葴女性、主訴は食欲不振、体重減少。上腹 部に約 $4 \mathrm{~cm}$ 人の massを触知し、胃内視鏡検査にて体中部 から胃角部にかけて大弯の易出血性のfold肥大がみられ た。その後腸閉塞を呈し、大腸癌による腸閉塞が疑われ た。大腸内視鏡検査では、前処置不良のため S 状結腸ま での観祭であったが、S 状結腸に半周性のBorr.2型病変 が想められ、ガストロ注腸検査を行ったところ、横行結 腸に全周性狭窄と胃内衤への穿通が認められた。注腸検 查翌日に高熱と腹部全体の圧痛、抵抗がみられ、穿孔に よる腹膜炎、敗血症が疑われ、问日に緊急手術を行った。 開腹時所見では、横行結腸の腫瘍は胃大弯に浸潤、瘦孔 を形成し、大網で覆われ一塊となっているが、腹腔内へ の穿孔もみられた。

症例 2 は60歳男性、主訴は食欲不振。左季肋部に小児 手拳大の腫瘤を触知、胃透視、胃内視鏡検査にて皆体部 大弯に㓮辺隆起を伴った陥凹性病変を認めた。大腸内視 鏡検査で同部位に腫瘍性狭窄を認ぬ、生検所見は中分化 型腺源であった。手術所見は、横行結腸に全周性腫隍を 認め、癌組織は結腸粘膜面から胃粘膜下組織まで浸潤し 瘦孔を形成していた。

悪性腫瘍による胃結腸瘦々稀な疾患で、また、結腸癌 原発によるものは、本邦報告例では 10 数例にすぎない。 我々が経験した胃結腸瘦を合併した結腸癌の 2 例を若立 の文献的考祭を加え報告する。 


\section{I -181 大膈穿孔症例の検时}

福井医科大学第 2 外科

堀内哲也、宮永克也、打波 大、木村哲也、下松谷匠、 谷川允彦、村岡隆介

1983年より1995年の間に当科で経験した大腸穿孔症 例は18例であり、原因疾患は大腸癌 5 例、特発性大腸穿 孔4例、医原性3例、欯室炎 2 例、異物 2 例、潰瘍 1 例、鎖 肛1例であった。年齢は0〜82歳。穿孔部位は右側結腸2 例、左側結腸 1 例、S 状結腸9例、直腸6例であった。発 症から手術までの時間は3時間〜8日間。手術方法は穿 孔部閉鎖のみを 3 例に、穿孔部閉鎖 + 人工肛門造設 5 例、腸切除のみ 3 例、腸切除+人工肛門造設を 6 例に行 った。術前WBC数は $1100 \sim 16900 / \mathrm{mm}^{3}$ 。術後合併症は、 創感染6例、肝障害5例、腎障害6例、DIC 1例であった。 臨床的SIRS の期間は0〜16日。入院日数は23〜93日で、 死亡例はなく、全例軽快退院した。

(1)原因疾患(2)年秢(3)穿孔部位(4)発症から手術までの 時間(5)術前WBC数(6)臨床的SIRS の期間、之術後合併症 の発生率との関係を検討した結果、(1)高秢者、(2)発症 から手術までの時間が長いもの、(3)術前WBC数が2000 以下のものおよび12000以上のもの、(4)臨床的SIRSの期 間が長いもの、では術後合併症の発生が多く、慎重な 術後管理が必要と考えられた。

\section{I-182直腸切断術を施行した壊死型虚血 性大腸炎の 1 例}

\section{総合木沢記念病院外科}

飯田 豊, 田辺 博, 伊藤英夫

【はじめに】消化管の虚血性疾患のうち主幹動脈に明 かな閉塞を認めないものは虚血性大腸炎と定義されて いる. 今回我々は急性腹症にて発症した壊死型虚血性 大腸炎に対し直腸切断術を施行した 1 例を経験したの で報告する.【症例】症例は73歳男性. 突然生じた腹 痛と下血を主訴に来院した。下腹部を中心とした压痛 と筋性防御, Blumberg 徵候を認めた. 緊急大腸内視 鏡検查を施行したところ, 肛門のすぐ口側から粘膜は 暗赤色に変色し, 浮腫状で易出血性であった. その後 腹膜刺激症状が増強し, 腸管壊死による穿孔の危険も 考えられたため, 汎発性腹膜炎の診断にて手術を施行 した，開腹すると，直腸に限局して漿膜面に暗赤色の 虚血性変化を認め壊死に陥っていた。 口側の壊死腸管 の境界は明瞭であったが, 肛門側の壊死腸管は腹膜反 転部を超えて小骨盤腔にあり, 肛門側直腸の viability が明かでないため Harrtmann 手術を施行した場合, 断端閉鎖部の縫合不全を招くことが危惧されたため直 腸切断術を施行した、【結語】直腸において壊死型虚 血性大腸炎が生じるのは極めて稀と考えられ報告する
$\mathrm{I}-183 \mathrm{n}-3$ 多体不飽和脂肪乳殽投与による細胞 性免疫維持作用 千葉大学第 1 外科

林 永規、田代覀彦、山森秀夫、森嶋友一、大坪義尚 杉浦敏之、古川勝規、板橋輝美、佐野涉、豊田康義 新田宙、中島伸之

【目的】n-3脂肪酸投与による細胞性免度維持作用をTPN 下熱傷ラッ恬いを用いて示してきたが、その機序を明らか にするためエ何州)代産生能、遅延型皮虙反店、GM-CSFから 検討した。【対象と方法】SD系ラ梳脂肪飼料で2週間飼

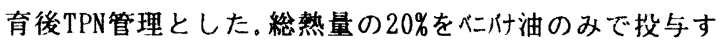
るN6群、総熱量の $20 \%$ 魚油のみで投与するN $3 \mathrm{H}$ 群、総熱 量の $20 \%$ 魯油/ベニイ十油 (1:1)で投与するN3M群、総熟量の 19\%をバハイ油、1\%をn一3脂肪乳唷で投与するN3L群、脂肪を 投与しないC群に分けた。 5 日後、背部に $20 \%$ の度熱傷を 作成し 48時間後に屠殺した。【結果】血清総脂肪酸構成： EPA、DHAはN3H、N3M、N3L群がN6、C群に比し増加 $(p<0.001)$ していた。GMCSF:N3H群がN6、C群に比し増加（p<0.05、p< 0.02)していた。PGE2、TXB2: 5 群間で差を認めなかった。 DTH:N3H群は他群に比し立進 $(\mathrm{p}<0.02)$ し、N3M群はC群に 比し克進 $(\mathrm{p}<0.03)$ していた。GM-CSFとDTH:両者の間には 正の相関 $(r=0.316 、 p<0.05)$ が認められた。結語】侵鎱下 の生体へのn-3脂肪乳剂投与で得られる細胞性免疫維持 作用の機序のひとつに、GM-CSFの産生充進が示唆された。

I -184 Dual energy x-ray absorptiometry(DXA)を 用いた肥满度別の周術期身体椿成成分变化の检討

神戸大学第一外科

北村有子、宇佐美真、磯篤典、笠原宏、

平井昭博、曹遠明、孫㓢、小谷程治、

金丸 太一、山本正博、斎藤洋一

【目的】DXAを用いて、消化器手術患者の周術期身 体権成成分の変化をBMI(body mass index)による肥满 度分類を基に梌討した。【対象及び方法】当科で施行 した胃切除術、大腸切除術、胆㤅摘出術の35例を対象 とした。術前のBMIの值により肥淗度をA群: BMI 25(5例)、B 群: $20 \leqq B M I<25$ (19例)、C群: BMI $<20$ (11 例)の3 群に分け、術前と術後 2 週目にDXA(Hologic QDR 2000) を用いてTM(総組量)、FAT(体脂肪量)、

\%FAT(体脂肪率)、LBM(lean body mass)、BMC(骨組 織量)を測定し、同時に体重、BMI、AC(左上腕周囲長) TSF (左上腕三頭筋部皮下脂肪厚) を測定した。【結果】 A群の術後に他群に比し\%FATは增加し、相対的な脂 肪の增加を認めた。従来からの身体指標であるAC、 TSF 值では周術期変化を反映する結果は得られなかっ た。【結語】1) DXAは正確に周術期身体組成変化 を測定し得た。2 ）術後\%FATは肥渵群では增加した。 
I -185 完全中心静脈栄養におうけるラット小腸棈 造の光顕、電顯的検討 -特にapoptosisの関与について鹿児島大学第一外科 ${ }^{1)}$ 、同手術部”、同第二解部 ${ }^{31}$

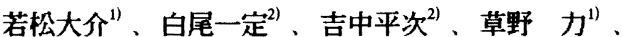
夏越祥次 ${ }^{17}$ 、馬場政道 ${ }^{1)}$ 、福元俊孝 ${ }^{11}$ 、愛甲 孝 ${ }^{11}$ 、津 山新一郎 ${ }^{3)}$ 、村田長芳 ${ }^{3)}$

(目的) 完全中心静脈栄養 (TPN) 施行時の小腸緁毛 の菱縮を、細胞構築や細胞周期の面から検討した。 (材料と方法) ラットを用いてTPN群と完全経腸栄養 (TEN) 群を作成、無拘束下に総投与力ロリ一 $250 \mathrm{Cal} / \mathrm{kg} / \mathrm{day}$ 、総投与量 $250 \mathrm{ml} / \mathrm{kg} / \mathrm{day} 、(\mathrm{NPC} / \mathrm{N}=210)$ で一週間管理し,BrdU50mg/kg ip後1時間で屠殺した。 䋐毛高はmicrometerで計測、apoptosis染色はTUNEL法で 行なつた。(結果) TPN群の䋐毛高 $(390 \pm 74 \mu \mathrm{m})$ は 正常群 $(580 \pm 123 \mu \mathrm{m})$ 、TEN群 $(540 \pm 135 \mu \mathrm{m})$ に比 べ有意に萎縮していた。抗actin染色で3群間に差異はな かった。TPN群の菱縮した䋐毛は電影的に細胞接着装 置、細胞内器官等で3群間に大きな差異は認められなかっ た。抗BrdU染色では3群間ともcrypt底部付近に晹性細 胞が琶められた。抗apoptosis染色ではTEN群は正常群 と同様に䋐毛先端付近に、TPN群では䋐毛下部にも晹 性細胞が認められた。(考察) apoptosis染色ではTPN 群でのみ成熟直後の細胞に陽性がみられており、TPN による絾毛菱縮にapoptosisの関与が示唆された。

I -186経腸栄養による術後粘膜障害の改善効果

神戸大学第一外科、大阪市立大学公衆衛生学* 宇佐美真、土師誠二、阪田和也、平井昭博、小谷 穣治、磯篤典、北村有子、曹遠明、孫凱、笠原宏、 山本正博、斎藤洋一、今村育男*

【目的】血中で測定可能な粘膜活性としてpostheparin plasma diamine oxidase（PHD）活性を測定し、 経腸栄養（EN）は高カロリー輸液（TPN）と比べ て術後の腸粘膜integrityの保持と microbial translocation （MT）の予防に有効であるかを検討した。【症例 ならびに方法】 Major operationの32例（食道8、胃全 摘17、蔳切例）を用い、EN群とTPN群を比較した。 $\mathrm{PHD}$ の測定は、ヘパリン投与後経時的に採血し、 HPLCでDAO活性を測定、AUCで算出し、MTの指標 として、血液培養、血中エンドトキシン（トキシカ ラーTC法、エンドスペシーES法）を測定した。

【結果および考察】PHDの前值は101.2 \pm 65.3 $\mathrm{pmol} / \mathrm{min} / \mathrm{m}$ であり、術後早期の2PODには、EN、 TPN群で70\%低下した（p=0.08）。10PODにはTPN群 では69.9土27.0（前值比82.7\%）とその回復は十分で

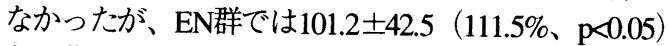
と回復は良好であった。【まとめ】術後の経腸栄養 は、低下した粘膜integrityの回復に有効である。
I-187 メチオニン投与量が腫瘍増殖とメチオニ ン消費量に及ぼす効果と影響について

久留米大学第一外科

吉積 司, 吉田祥吾, 石橋生哉, 野明俊裕,

白水勇一郎, 白水和雄

【目的】メチオ二ン(MET) 不之療法時によ゙の柦度のMET濃 葟で腫㾇增殖が抑制され得るか在解明する目的でMET 濃度が腫瘍細胞の増殖に与える影響とMET消費量につ いてinvitroで検討した【ラ法】ヒト食道癌細胞株YE 3を用い，培養液をM-0:MET矢乏群, M-1:MET1 100添加群, M-2:MET1 40添加群, M-3:MET1 20添加群, M-4:MET1 10 添加群, M-5:MET含有標準培養液群の6群に分けて培養 し,腫瘍細胞数上MET消費量を求めた【結果】腫瘍細胞 数はM-0よM-1間, M-3よM-4間に有意差はなかったか，他 群!さMET投与量の増加と共に有意に増加した，細胞増加 率も細胞数こ相関し推移した。MET消費量はM-0からM-4 までは緩やかな増加曲線を描くがM-5に洷る際指数関 数的にMET消費量が増加した以上より腫煬細胞の増殖 はMET濃度と相関し，M-3からM-4間では腫場増殖が定常 状態になっている可能性が考えられた

【結語】腫瘍細胞増殖之MET消費量ははMET濃度によって 修飾されており，腫瘍のMET消費量が抑制されることに よって腫瘍増殖が抑制さ扎ていることか心唆された

I -188 肝外転移を伴う肝細胞癌の治療

北海道大学第一外科 中西一彰、宇根良衛、羽田 力、大久保尚、富岡伸元 嶋村 剛、松下通明、佐藤直樹、中島保明、内野純一 【目的】肝細胞癌遠隔転移例につきRetrospect iveに検 討した。[対象・方法]対象は’ 85年から’94年までに教室 で初回切除した肝細胞癌 300 例中、同時性転移7例(肺3 例、骨2例、リンパ節2例)、異時性転移32例 (肺27例、骨7 例、リンパ節 3 例、脳 2 例、副腎 1 例; 重複あり)。検討項目; 1) 同時性転移例に対する治療と予後。2) 異時性転移例 の肝内再発の有無。3) 異時性転移例の治療。4)肝内転移 に対する治療法別の異時性転移例の予後。5) 異時性肺 転移例の治療法別の予後。(成績】1)肺転移切除例 (2例) は6力月、 2 年で死亡。骨転移切除例は 2 年で死亡。リンパ 節転移切除 2 例中 1 例は 1.5 年間無再発生存中。2)肝内転 移併発は 26 例 $(81.3 \%$ )。3) 肺転移に対し肺切除6例、動 注療法11例。骨転移は3例に放射線療法。リンパ節転移 は全例切除。脳転移は 1 例切除。4)肝内転移切除例の平 均再発後生存期間は他の治療に比べ有意に良好 $(\mathrm{p}=0.0$ 4)。5)肺切除例の平均再発後生存期間は有意に良好 ( $=0.03$ )。肺切除例の肝内転移巣は十分なコントロール であった。【結語】同時性転移例では転移巣の切除によ り、また異時性は肝内転移を十分コントロールしたj えで遠隔転移を治療する事で予後の延長が期待できる。 
I -189 䀒右葉切除前の門眽右枝塞栓術の経䮴

网山大学医学部第 1 外科

紊蕧信也, 津下宏, 森雅信, 浜崎啓介, 岡林孝弘, 璔本良夫，八木孝仁，田中紀章，折田毫三

[目的]当施設では，1992年から肝右葉切除の術前 に門后右枝を塞拴し, 右葉の荎縮と左葉の代供性の再 生肥大を促すことにより, 手術の安全性の向上を目指 している. 今回, この方法の残存肝容積に及ぼす効果 と副作用を中心にその成績を報告する。［対象と方法] 対象患者は 16 人（男13人；女 3 人）平均年路 56.4 歲（3 8-65歳)，原疾患は，肝細盷虎 10 例，胆管細胞癌 1 例， 肝門部胆管癌5例であった。塞栓物筫は、主としてシア ノアクリレートを用いた。[結果]門眽塞栓直前と塞 拴後1週目の肝機能值を比較したところ、GOT、GPT、血 清總ビリルピン、KICG值とも有意の変化は見られなか つた。次に、volune CT法で塞栓前と塞栓後 3 週目の容 積を比較したところ、盰右葉容樌は、平均では $934 \mathrm{~cm}^{3}$

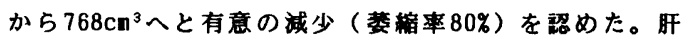
左葉容積は、平均では $311 \mathrm{~cm}^{3}$ から, $418 \mathrm{~cm}^{3}$ へと有意の 增加（肥大事139\%）を梕めた。［結諭]肝右葉切除前 の門后枝塞拴術は安全であり、残存予定肝(肝左葉) の代償性目大を期待するにも有用な方法と思われた。

I -190 肝腫瘍の存在区域診断 - Portal Angio Echoとその問題点一

東京女子医科大学消化器外科 ${ }^{11}$, 同内科 ${ }^{21}$

片桐 聡 ${ }^{1}$ 、高崎 健、次田 正、山本雅一

大坪毅人、秋山和宏、斎藤明子 ${ }^{21}$

(目的) Portal Angio-Echo(以下PAE)を用いた、肝腫 瘍存在区域診断とその問題点について検討した。

（対象）1988年～1995年まで肝切除施行肝細胞癌のう ち PAEを施行した91症例、111結節である。

（方法）US誘導下に経皮的に肝内門脈枝を $22 \mathrm{G} ・ \mathrm{PTC}$ 針にて穿刺後、炭酸ガス 8 15ccを注入しその前後の 変化をUSにて観察した。検討は手術所見と比較して、 PAE、US、CT、Angiography の正診率と、PAEの誤診 例についておこなった。

(結果) 正診率は、PAE 90.1\%、US 75.6\%、CT 63.2\%、 Angio 72.3\% であった。各境界ごとの正診率は、 S7/8 PAE 100\% 、US 80.9\% CT 64.9\%、Angio 81.8\% S5/6 PAE 70.4\% US 66.7\% CT 55.6\%、Angio 52.6\% S4/8 PAE $90.3 \%$ US $74.2 \%$, CT $67.9 \%$, Angio $80 \%$ S4/5 PAE 100\% 、US 83.3\%、CT 67.9\%、Angio 50\% $\mathrm{PAE}$ 誤診例は、S5/6の 8結節とS4/8の 3結節であった。

（まとめ）1） PAEは肝細胞癌存在区域診断において 高い正診率を示した。2）PAEにおけるS5/6境界診断 には今後問題点として検討の余地が残された。
I -191 小児期における肝腫瘍の治療成績とその

検討

徳島大学第一外科

嵩原裕夫、石橋広樹、吉田金広、田代征記

[目的と対象］小児肝腫瘍12例の治療成績と予後に ついて検討した。その内訳は、良性腫場が 2例（間葉 性過誤腫、血管内皮腫）、悪性腫瘍が10例（肝芽腫 5 例、肝細胞癌 1例、未分化肉腫1 例、転移性神経芽腫 3例）である。 [結果] 良性腫瘍 2例の予後は良好で、 $\mathrm{S}_{4}$ から発生した間葉性過誤腫例では右三区域切除を 余儀なくされ、剥離により完全に遊離された肝外胆管 が術後血流障害による閉塞をきたし、10か月後に左肝 内胆管・十二指腸吻合術を行ったが、術後 5 年順調に 経過している。悪性腫晹10例のうち、生存例は切除可 能な肝芽腫 4 例と末分化肉腫 1 例および化学療法で肝 腫瘍が消失した転移性神経芽腫 1例である。死亡例は 切除不能であった肝牙腫 1例と肝細胞癌 1例および転 移性神経芽腫 2例であった。 [考察とまとめ] 集計で は、StageIIB 以上の 2生率は7.9\%と低いが、教室にお ける生存例も切除可能なStageIIA までの症例であった。 また、肝切除後の肝外胆管が剥離により完全に遊離さ れ、術後血流障害による閉塞や狭窄が懸念される例で は、肝切離面に可及的近い胆管で腸管との胆道再建を 行なうべきである。

\section{I -192腹腔鏡下肝部分切除術一腹壁吊り上げ法} を併用したPringle 法を用いて

慶應義塾大学外科

若林 剛、大上正裕、島津元秀、渡辺昌彦、北島政樹

われわれは腹壁吊り上げ法を併用したPringle 法を 用いて、開腹下の肝切除術とほぼ同様の手術手技で腹 腔鏡下に肝部分切除術を施行し得たのでビデオで供覧 する。症例は60歳女性で、1 年6 6 月前に下行結腸早 期癌に対して腹腔鏡下下行結腸部分切除術を行った。 肝外側区域 $\left(\mathrm{S}_{3}\right)$ に約 $4 \mathrm{~cm}$ の大腸癌肝転移巣（単発）を 認め、腹腔鏡下肝部分切除術の適応と判断した。手術 は腹腔鏡を挿入し気腹、腹腔鏡用超音波探触子により 肝切除範囲を決めた後に気腹を解除、以後腹壁吊り上 げ法により肝切除を施行した。肝十二指腸間膜にター 二ケットを置き、肝切除時にPringle 法を施行した。 肝切除には、マイクロ波凝固装置、腹腔鏡下手術用超 音波吸引装置、バイポーラー高周波メス、そして argon beam coagulator を使用した。 $\mathrm{S}_{3}$ のGlisson お よび主な肝静脈はクリップと結紮を併用し切離した。 出血量は $240 \mathrm{~g}$ で肝切除時間は 3 時間弱であった。切除 肝はENDOCATCH-II に入れ前回手術創より摘出した。肝 断端に挿入したドレーンは術後 3 日目に抜去し、患者 は経過良好で術後4日目に退院した。 
I -193肝細胞癌切除手術前後における血清甲状 腺ホルモン結合蛋白 (TBG) 值の検討

\section{島根医科大学第 2 外科}

大森治樹、林 貴史、山野井 彰、橋本直樹、 山口峰一、祖田由紀子、中島裕一、永末直文 【目的】甲状腺机モ結合蛋白 (TBG) は主に肝細胞で合 成されている。我々は、肝癌症例の術前後の血清TBG, T4, T3，FreeT4值の推移を検討した。【対象及び方法】 肝癌切除19例、正常肝を持つ肝癌以外の手術 6 例、健 常人 5 例の術前、術後 $1,2,3,4$ 週目の血清TBG, T4, T3, FreeT4値を比較検討し、肝癌症例中TBG 高値群 11 例 ( mean $\pm 2 S D$ 以上）と正常值群 9 例の臨床病理学的因子 についても検討した。【結果】術前の肝癌症例とコンロ 一症例の血清 TBG, T3值では、肝癌症例の方が高值であ った $(\mathrm{P}<0.05)$ 。TBG高値群中 9 例では、TBG値が術前と比 較して術後各週全てにおいて低下していた $(\mathrm{P}<0.02)$ 。 TBG 高值群と正常値群を比較すると、高値群でT3値が 高かった $(\mathrm{P}<0.01)$ 。両群における臨床病理学的因子に は差がなかった。【結語】1)肝癌の約50\%で TBG産生 が認められた。2) TBG 産生型では、血清T3值の上昇が みられた。3)術前後のTBG 值の推移より、肝癌がTBG を産生していると考えられた。4) TBG 産生型の肝癌で は、TBG値が腫瘍マーカーになり得ると考えられた。

I -194肝癌に対する温熱化学療法の試み一奏効例 3 例の報告

\section{京都府立与謝 $の$ 海病院外科}

閑啓太郎, 内藤和世, 水田成彦, 大森浩二, 大森吉弘 温熱療法は癌に対する集学的治療法の一つとして放 射線療法や化学療法との併用においてその効果が報告 されている。今回われわれは手術不適応の肝癌 3 例に 対し温熱併用動注化学療法を施行し好結果を得られた ので報告する。3 例の内訳は胃癌の肝転移 1 例、肝細 胞癌 1 例、肝内胆管癌の肝再発 1 例である。温熱療法 は松口社製RF波誘電加温装置 thermox 500を用い、400$500 \mathrm{~W}$ の出力で50-60分間の加温を行った。施行回数は 週1-2回の頻度で計 5-6回施行した。併用化学療法はMMC ,CDDPを動脈内留置リザーバーよりの動注にて投与、加え てフッッロを経口投与した。3 例とも治療後の検查にて腫 癔の縮小を認め、癌治療学会の固形癌化学療法効果判 定基準により” PR”と判定された。さらに腫瘍マーカーの 低下も認められた。現在、手術不適応肝癌に対しては TAE, PEITやマイクロ波凝固壊死療法といった治療法が選択 されているが、今回の結果から本治療法すそれらとと 屯に肝癌治療の有力な治療選択肢と成り得ると考えら 机た。
I-195 熱湯局注療法 (PHOT) 後に切除術 を施行した訮細胞泉の 2 例

済生会御所病院外科 ${ }^{11}$, 同放射線科 ${ }^{2)}$

朴 秀一1), 中谷勝紀 ${ }^{11}$ ，笠松 稳 ${ }^{11}$

石井久史 ${ }^{1)}$, 成清道博 ${ }^{1)}$, 本田伸行 ${ }^{2)}$

エ夕ノール局注療法（PEIT）に匹敵する治療法と して熱湯局注療法（PHOT）が注目されているが，今 回我々はPHOT後に外科的切除を施行しその効果を確 認できた肝細胞癌の 2 例を経験したので報告する。

【症例1】42才, 男性。各種画像検査で肝 $\mathrm{S} 4$ に $4 \mathrm{~cm}$ 大の肝細胞癌と診断。超音波ガイド下に熱湯を計 $45 \mathrm{ml}$ 注入しPHOT施行。その後腫瘍残存が疑われ肝 左葉切除術施行。腫瘍は $4.5 \mathrm{~cm}$ 大で単結節, 充実性で 腫瘍内隔壁は殆ど認めず，壊死部分は $95 \%$ であった。

【症例2】61才、男性。各種画像検査で肝S5に3.5 $\mathrm{cm}$ 大の肝細胞癌と診断。超音波ガイド下に熱湯を計 $55 \mathrm{ml}$ 注入しPHOT施行。その後腫瘍残存が疑われ核 出術施行。腫瘍は約 $3 \mathrm{~cm}$ 大で多結節癒合型、充実性で 腫瘍内隔壁を有し壊死部分は60\%で病理組織学的に は隔壁を含めた壊死部分を認めるものの隔壁を境にし て壊死部・非壊死部の境界が明暸な部分も認めた。以 上よりPHOTは重篤な副作用を認めず有用な治療法で あるが, 腫瘍の構築型により至適注入量 · 回数を決定 する必要があると考えられた。

\section{I -196 若年者（40歳末満）肝細胞癌症例の検討}

\section{日本大学第 3 外科}

河野 悟, 高野靖悟, 高橋知秀, 伊藤 豊, 大石 均 渡辺善広, 関 芳訓, 桧垣時夫, 森口正倫, 中田泰彦 佐藤一雄, 高木恵子, 山崎 猛, 中村正彦, 横山武史 川上新二郎, 三木敏生, 榎本敋矢, 岩井重富

【目的】本邦の若年者肝細胞癌は比較的稀であり, 諸 家にていくつかの特徵を示唆されている。今回, 当科 で経験した40歳末淽肝細胞癌症例について検討した。 【対象と方法】1985年10月から1995年10月までの肝細 胞癌409例中, 40 歳末満の9例 (2.2\%)を対象とした。こ れらの1)背贯因子, 初発症状, 2)肝機能, AFP, 腫㾺随伴 症候群, 3)肝切除群と非切除群別の肉眼的分類 - 腫病 径・門脈腫准塞栓・遠隔転移の有無・再発とその期 間 ·臨床病期 · 䀒硬変の有無 - 死因 - 予後について検 討した。【成績】1) 背景因子は年齢が18歳 39歳で平 均年齢 30.9 歳, 男性 8名, 女性1名であった。肝炎ウ1Nスマー カーは全例HBs抗原陽性であった。2) AFPは全例陽性で, 3 例に $10000 \mathrm{ng} / \mathrm{m} 1$ 以上の異常高值を認めた。3)肝切除群 は6 例で,残肝再発は全例, 肺・骨転移が4例に見られ、 平均生存期間は585日（生存中の1例を除く）であった。 非切除群は 3 例, 平均生存期間は89日であった。死因 は生存中の1例を除き6例が癌死, 2例が肝不全であった。 
I -197 若年者肝細胞癌(HCC)の背景因子の検討

\section{香川医科大学第 1 外科}

國土泰孝、谷内田真一、石村 健、岡野圭一、森 誠治、 唐沢幸彦、合田文則、濱本勲、岡田節雄、若林久男、 白杵尚志、前場隆志、前田肇

(目的)若年者HCCの背景因子と予後に関し検討した。 (方法)相対的治癒切除以上のHCC104例を50歳未満、以 上で若年者群(Y群, 12例) と高齢者群(O群, 92例)に分けた。 (結果)O群はHCV抗体陽性(70\%)が,Y群はHBs抗原陽性 (80\%)が多かった(p<0.0001)。ICGR15はO群で19.8\%,Y群 $14.9 \%$ あった。腫昐数はO群で1.51個, Y群で1.67個,最 大腫瘍径はO群で $37.0 \mathrm{~mm}, \mathrm{Y}$ 群で $36.8 \mathrm{mn}$ であった。被膜 形成(fc),被膜浸潤(fc-inf), 隔壁形成(sf), 門脈浸潤(vp), 肝 内転移 $(\mathrm{im})$, 切離面浸潤 $(\mathrm{tw})$ 陽性率はO群で $80 \%, 66 \%$, 50\%, 28\%, 23\%,16\%にY群では75\% 58\%, 58\%, 17\% $16 \%, 25 \%$ であった。 5 年生存率はO群で $48.2 \%, Y$ 群 $76.2 \%$ であったが非癌死を除外するとO群の生存率は $60.6 \%$ と

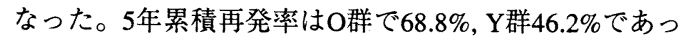
た。(結語)O群はC 型肝炎を Y 群では B 型肝炎を基礎疾患 としていた。病理学的に両群に差はなかったが5年生存 率はY群で良好な傾向がみられた。Y群では肝不全死が 少なく、再発率も低いためと思われた。若年者肝癌は積 極的な手術により良好な予後が期待できると思われた。

\section{I -198 高齢者肝細胞癌についての検討 \\ 日本大学第三外科 \\ 中村正彦、高野靖悟、関 訓芳、渡邊善広、 檜坦時夫、森口正倫、高橋知秀、伊藤 豊、 大石 均、河野 悟、高木恵子、山崎 猛、 \\ 川上新仁郎、横山武史、岩井重富}

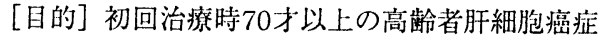
例について検討したので報告する。[対象] 当科で 経験した 464 例の肝細胞癌症例のうち70才以上の高 齢者肝癌症例55例。 [結果] 高齢者群に打いて、 HCV抗体陽性 41例、HBsAg陽性2例であった。肝機 能、血液検査データは、高龄者群と非高龄者群にお いて有意美を認めなかったが、AFP值は高齢者群 $10038.0 \pm 42054.4 \mathrm{ng} / \mathrm{ml}$ であり非高龄者群と比較し て有意に高值であった。治療法は高龄者群は手術 27 例、TAE療法20例、リザーバーによる肝動注療法1

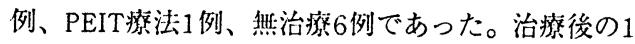
年生存率 $7.1 .1 \%$ 、5年生存率は $46.5 \%$ であった。[結 語了缐龄者群では、C型朋炎合併例が多く、AFP値 高值を示すものが多かった。また治療法では手術の 割合が少なく、TAE潦法、無治療の敖合が高かった。 治療後の累栍生存率は高龄者群、非高龄者群間で有 意差を絜めず、䯩龄者といえども非滈齢者と同等の 治療体系に上る治潦が必要であると考えられた。

\section{I -199 動腺血行途絶肝に対する門脈部分動脈化 術の臨床経験}

王子総合病院外科1)、北海道大学第 2 外科 ${ }^{2}$

佐藤幸作 ${ }^{1}$, 高橋 透 ${ }^{1}$, 水戸康文 ${ }^{1}$, 岩井和浩 ${ }^{1}$, 若松 豊 ${ }^{1}$, 市村龍之助 ${ }^{11}$, 平口悦郎 ${ }^{2}$, 富山光広 ${ }^{21}$,加藤紘之 ${ }^{21}$

【はじめに】今回我々は肝右葉切除の際、残存肝の動 脈枝が再建不能となりAPSにより肝の動脈血行再建を 行った 1 例を経験した。

【症例】患者は6 8 荗、女性. 平成元年 3 月中部胆管 痹にて䐙頭十二指腸切除術を施行. 平成 5 年 5 月肝門 部肝管再発にて肝右葉切除術を施行. この祭左肝動脈 損傷により肝動脈血行途絶となった．肝動脈再建が困 難で、総肝動脈門脈端側吻合により、肝の血行を保持 せんとした. 術後肝不全は回避し得たが、軽度の食道 静脈瘭形成などの門脈圧充進症による臨床症状が出現 した. 術後 4 カ月に動脈門脈吻合を経動脈的カテーテ ルによって閉鎖し、門脈圧充進症症状は消失した，そ の後 2 年を経過し肝機能障害、肝萎縮等は認めず、ま た、原疾患の再発も認めない.

【まとめ】APS後の門脈圧六進症に対しては動脈門脈 吻合の閉鎖せざるをえないが、動脈門脈吻合を閉鎖し ても側副血行路からの動脈血流により肝機能は良好に 維持し得たことが確認された。

\section{I $-200 \quad$ 肝切前後のアシアロシンチにおける HH15、LHL15の变動}

自治医科大学消化器一般外科 ${ }^{11}$ 、同救急医学 ${ }^{21}$

近藤 恵 ${ }^{11} 、$ 安田是和 ${ }^{21}$ 、柴崎淳 ${ }^{11} 、$ 石橋敏光、

岡田 創、服部照夫、秋元明彦、佐藤宗勝、山下圭輔、 金澤曉太郎

【目的】肝切前後のアシアロシンチにおける H H 15、 L HL 15 の変動の意味を検討するため、術前後のlabo data、肝容積を比較した。

【対象と方法】対象は1993年7月から 1995年2月まで に当科で施行した肝切除例 11 例である。術前及び術 後3ヶ月、6ヶ月、1年においてアシアロシンチを施行、 HH15、LHL15を算出し、Alb、Ch-E、ICG15、CTで測 定した肝容積の変化を比較検討した。

【結果】HH15は術後1年において、LHL15は術後3ヶ 月、1年において有意に改善した。Alb、Ch-Eの変化 はなく、ICGは術後 1 年において有意に悪化した。肝 容積の術後6ヶ月、1年における有意差はなかった。

【結論】肝切後において、容積に差はないのにHH15、 LHL15が改善しているということは、単位容積あたり のASGPRが増加していることが予想される。 
I - 201 肝切除術後早期の肝脾体積変化の解析

\section{東京慈恵会医科大学外科学講座第 1}

畧村泰樹, 和田知可志, 小林進, 野田剛, 伊坪喜八郎 [目的] 肝切除術後早期には形態的肝再生に伴い脾 体積が種々変動する. 術後の肝脾の相互作用や門脈血 行動態の変化などに関する手掛かりを得ることを目的 として, 以下検討した。

[対象と方法] 術前, 術後1週および6週にCT撮影を 行った27例を対象とした. CTから残肝体積と脾体積を 経時的に計測した. 形態的肝再生, 脾体積変動のパラ メータとして残肝増大率（残肝体積／術直後残肝体 積）, 脾增大率（術後脾体積/術前脾体積）を用いた。 対象 27例を切除率別にI: 0.4未满 $(n=5)$, II: 0.4 以上 0.6 未満 $(n=8), \mathrm{III}: 0.6$ 以上 0.8 未満 $(n=11), \mathrm{IV}: 0.8$ 以上 $(n=3)$ の群に分け, 脾増大率を比較した.

[結果] 脾体積と残肝体積はともに術後1週で著しい 変動を示した. 術後6週での残肝増大率と脾増大率は 正相関 $(r=0.636, p<0.05)$ を示した. 脾增大率はIから IV 群の順に大きくなる傾向を認めた $(\mathrm{p}<0.05)$.

[結論] 脾と残肝の体積変化は密接に関連し,脾体積 の増加は肝再生を抑制しなかった. 脾体積変化の背景 には, 術後早期の門脈系のうっ血とこれを補正する門 脈圧調圧機構( buffer response) の存在が示唆された。

I - 202 肝硬変の肝線維化過程における細胞外マ トリックスの動態とその定量化の意義

福島県立医科大学第 2 外科

佐藤尚紀，畠山優一，五十嵐渉，小野俊之， 小山善久, 井上典夫, 土屋 敦雄, 阿部力哉

【目的】肝線維化率(LFR) と肝切除後の肝再生能には 負の相関があることを肝硬変ラットを用いて検討報告 してきた。今回、肝線維化にともない肝に蓄樻する細 胞外マトリックス (ECM)に注目し、その定量の意義と相 互関係について検討した。【対象・方法】肝切除26例 の病巣以外の肝組織標本にアザン染色を行い自動画像 解析装置を用いてLFR を測定した。更に、 laminin $(L M)$ 、f ibronectin $(F N) 、 I \cdot I I I \cdot I$ 型 collagen (T I C, T IIIC, TIVC) をABC法にて免疫染色し、

自動画像解析装置を用いて定量化し、それぞれのECM 量、LFRとECM量を比較検討した。【結果】各ECM間にお いて、LMとTIC、LMとTIVCの各2群間に相関が認められ た。LFRとECMとの関係ではLFRとTIIIC、LFRとTIVCの各 2 群間に相関が認められた。【結語】1)画像解析装置 を用いてECMの定量化が可能であった。2)肝硬変の肝線 維化過程においてECMは增加し、一定の規則性があると 考えられた。3) ECMは肝再生能に何らかの影䡴を及ほし ており、その定量化は硬変肝切除の際の肝再生能を予 測する指標となりうると考えられた。
I - 203培養内皮細胞障害からみた閉塞性黄疸及 び肝硬変例における好中球活性化に関する検討

\section{千葉大学第 1 外科}

清水善明、宮崎勝、安蒜聡、清水宏明、外川明、 大塚将之、笹田和裕、塩原正之、吉岡茂、加藤厚、 尾本秀之、中村俊太、中島伸之

【目的】閉塞性黄疸及び肝硬変の各種障害肝の好 中球により惹起される血管内皮細胞障害を好中球活 性化指標として検討した。【方法】培養と卜臍帯静 脈と phorbol myristate acetateを用いて活性化した 好中球を混合培養し、培養液中のLDH、トロンボモ ジュリン (TM)、顆粒球エラスターゼを測定した。対 象として閉塞性黄疸減黄前群 ( I 群)、減黄群 (II 群)、 肝硬変群( III 群)、正常肝機能群( IV 群) の 4 群におい て手術前、肝切除後 7 日目の好中球に関し検討した。

【結果】手術前の検討では、LDHは IV 群と比較して II 、III群は有意に高值を示したが、I 群は有意差を認 めなかった。TM、顆粒球エラスターゼも IV 群と比較 して II 、III 群で高值を示した。肝切除後 7 日目では II 、III 群はLDH、TMともにIV 群の $1.2 \sim 1.8$ 倍の高值 を示した。【結語】各種障害肝における好中球は、 肝病態に応じ既にpriming状態にあると考えられ、特 に閉塞性黄疸例ではPTBDによる減黄により好中球は priming状態となり、術後臓器障害発生機序に関して この観点より検討する必要があると考えられた。

I -204肝膵同時切除後のKupffer細胞を介した肝 再生抑制機構に関する実験的検討

東北大学第 1 外科

力山敏樹、鈴木正徳、福原賢治、海野倫明、坂本宣英、 竹内丙午、内山哲之、松野正紀

[目的］Rat肝荤同時切除モデルを作成しKupffer細 胞を介した肝再生抑制機構を検討した。 [方法] SD 系雄性Ratに70\%肝切除( $\mathrm{Hx}$ 群)、70\%肝切除と約70\%荤 切除(HPx 群)を行い門脈血清を分離、肝細胞・Kupffer 細胞混合培養に門脈血清を添加し ${ }^{3} \mathrm{H}$-thymidineの取込 みによるDNA合成能を測定した。また門脈血清添加 Kupffer細胞単独培養上清を濃縮 ·添加し肝細胞DNA 合成抑制効果を検討した。 [成績] 術後 $1 h$ 門脈血清添 加混合培養では、Hx群がcontrol(無血清)の90.5土

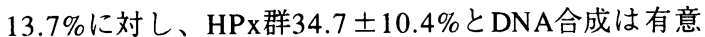
に抑制され、3時間でも抑制傾向が認められた。術後 $1 \mathrm{~h}$ 門脈血清にて刺激したKupffer細胞培養上清濃縮液 を $1 \mathrm{mg}$ 蛋白 $/ \mathrm{ml}$ 添加した肝細胞の ${ }^{3} \mathrm{H}$-thymidine取込みは、 $\mathrm{Hx}$ 群 $10.8 \pm 1.6 \times 10^{4} \mathrm{DPM} / \mathrm{mg}$ 蛋白に対し、HPx群 $2.9 \pm$ $1.0 \times 10^{4} \mathrm{DPM} / \mathrm{mg}$ 蛋白と有意に低下していた。［結論］ HPx 群術後 1 ～3h の門脈血清添加Kupffer細胞による液 性抑制因子産生が示唆され肝腪同時切除後のKupffer 細胞を介した肝再生抑制機序の存在が推察された。 
I - 205術後肝不全に対する血液浄化法の意䣡 国立大阪病院外科 亡問題点

中川英刀、上田篤史、蓮池康徳、辛 栄成、福田和弘、

三嶋秀行、柳生俊夫、小林研二、吉川宣輝

激症肝炎に対しては各種血液浄化法が盛んに行われ、 攱近ではその生存率の向上に賁献してきている。しかし 肝䁍手術後に代表される術後肝不全においては、その定 義や病態生理、さらに治癔法として各程血液浄化法の意

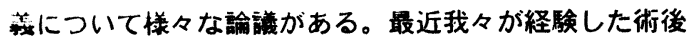
肝不全の7例に対して、血獎交換のべ40回、ビルルビン 吸著のべ6回、CHDF3症例、PMX1回といった各種 血液浄化を施行し、4 例が肝不全から脱却、2 例を救命 し得た。この 7 例のうち 4 例が何らかの感染症を合併し ており、急性留不全やD।Cなど他の臓器不全を 3 例で 認めた。血液浄化法は術後肝不全の根本治療ではない が、肝機能の回復や肝不全の原因の 1 つである感染症の control できるまでの間、肝機能の補助し、肝不全から MOFという流れ中で時間を稼ぐことができる有意義な方 法であり、術後肝不全にたいして樌極的にすべき治病法 である。しかし、blood access からの感染や血栓形成 などblood access の問題が 7 例のうち 3 例に発生し、 また高額医療で家族からの拒否の症例もあり、漛々な問 題点を有している。

I -206 肝切除症例に対する経門脈的インスリンー グルカゴン投与の検討

\section{鹿児島大学第一外科}

浜之上雅博, 田辺 元, 塗木健介, 吉留伸朗

平田晋吾, 上野信一, 小倉芳人, 川井田浩一

前村 誠, 小林泰之, 愛甲 孝

[目的]肝切除例に安全な経門脈的投与経路を作製し、 インスリンーグルカゴン (IG)投与を行い効果を検討した。 [方法] 肝切除症例 15 例に対し、硬膜外麻酔用カテーテ ルを大網静脈に留置し腹壁に固定し、IG門脈投与経路と して使用した。IG投与量はI:20U+G:1Uを24時間で持続投 与した。投与期間は術直後より 3 日間、長期例で7日間持 続投与を行った。術後経過につき1994年以降の肝切除非 投与症例 54 例と比較検討を行った。両群間において臨 床的背景に差はなかった。[成績] 経門脈 IG投与による 術中、術後合併症はなかった。IG投与群は投与期間中、 インスリン抵抗性糖尿病症例を除き血糖は100〜200 $\mathrm{mg} / \mathrm{dl}$ を推移し、他の処置を必要としなかった。また術後 総ビリルビンが $2 \mathrm{mg} / \mathrm{dl}$ 以上を示す例はなく非投与群より 有意に低値であった。[結論]経門脈的 IG投与は、術後糖 代謝を高め、ビリルビン代謝を維持した。本方法による 経門脈的 IG投与は安全であり、肝切除術後の肝機能維持 および肝障害抑制に有用であると考えられた。

\section{I -207䀒切除後高ビリルビン血症における旰静眽血 ヒアルロン請值の变動}

\section{槊田保健術生大学消化器外科第 2 科 \\ 石原 傎、宫川秀一、三浦画}

目的:旰切除後高ビリルビン血定はしはしば不可逆とな り死へと僬行する合併定の一つである.今回、我々は肝

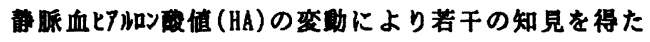
ので垠告する. 対参:最近 2 年間に行った旰切除街 21

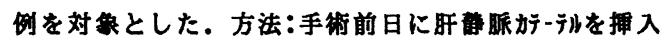
し、手術前および街後1日目より7日目まで新洞内皮佣 胞償能の指樏としてHAを揤定した。また、術後䋓ビリ比” ン(T.B)の変娌により3群に分けた.1群:街後 T.Bの上昇 が5mg/dl以下で2遇間以内に $2 \mathrm{mg} / \mathrm{d} 1$ 以下に低下、2群： $\mathrm{T} . \mathrm{B} か ゙$ 術後 2 通間以上 $2 \mathrm{mg} / \mathrm{dl}$ 以上 $5 \mathrm{mg} / \mathrm{dl}$ 以下を逐、 3 群:術後 $5 \mathrm{mg} / \mathrm{dl}$ 以上で渐增. 結果:術前HA值は、3群 が1,2群に比し有意に上昇していた。術後第1日目HAは、 1 群 $150.4 \pm 136.1 \mathrm{ng} / \mathrm{ml}, 2$ 群 $236.0 \pm 132.1 \mathrm{ng} / \mathrm{ml}, 3$ 碚 12 $03 \pm 513.4 \mathrm{ng} / \mathrm{ml}$ と、3群は 1 , 2群に比し有意に上昇して いた。術後第 7 日目HAは、1群76.0 $74.1 \mathrm{ng} / \mathrm{ml}, 2$ 群 154 . $3 \pm 76.4 \mathrm{ng} / \mathrm{ml}, 3$ 群 $2036.2 \pm 1065.0 \mathrm{ng} / \mathrm{ml}$ と、3 群は 1,2 群に比し有意に上昇し、術後第1日目より增加した。 考察:街後高ビリ牒”侐定の発定およびその逐延化に

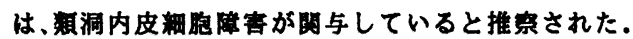

I -208旰切除時の新鮮凍結近漿の必要性について 日本大学第3外科

桧垣侍夫、森口正偷、高木恵子、小杉浩司、河野悟

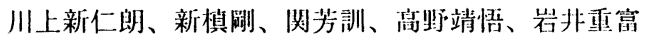

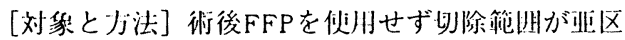
域切除以上の30例を組織学的に正常朋、慢性州炎、MF 硬変群にわけ、非沏除6例を加えた36例を刘象とし 経日的にブロトロンビン特间(PT)、ヘバブラスチンテ スト (HepaT)、フィブリノゲン (Fib)、アンチトロ ンビン・III（AT・III）を测定し比洨検傠をした。[紏果] PT.HepaTの変動は、正常訮、慢性皮炎群では3日目よ り術前値に対して有意差がなくなり、正常値に回復し 非肝切除群とも有意差はなかった。征硬変群は他の3 群との比較で術後有意に低值であった。Fibの変動は 肝炎、肝硬変群は他の2群とは有意に低值を示したが 正常範囲内であっだ。AT・四の変動は肝切除群は3日 目まで低下し続け、正常肝、慢性訮炎群では5日目以 降正常値に近い値となるが、朋硬変群では他の3群に 対し14日目まで有意に低值を示した。[結語］正常肝 慢性所炎では術後FFPの投与は必要ないと思われた。 AT·は凝固因子に比べ合成六進が遅延しており術後 早期のFFP投与はむしろ生体内でのアンバランスを生 じる可能性がある。肝硬変合併例では各因子を测定し 病態にあった補充が必要である。 
I - 209 肝切除周術期におけるphenolsulfonphthalein (PSP) 経口負荷試験の意義

\section{九州大学第 2 外科}

島田光生、竹中賢治、調 憲、藤原 雄、祇園智信、 杉町圭蔵.

【はじめに】肝切除周術期のPSP経口負荷試験の意義 を明らかにした。【対象・方法】肝切除を施行した48 例を対象とし、PSP経口試験（早朝空腹時に $30 \mathrm{mg}$ の PSPを $300 \mathrm{ml}$ の水に溶解し捸取させ昼食までは絶食、以 後は自由飲食可とし24時間蓄尿中のPSP量を定量）を 術前、術後3、7、14日目に施行した。PSP尿中排泄率 と臨床デー夕(術前肝機能、手術侵襲、合併症の有無な ど)の相関を検討した。【結果】術前PSP尿中排泄率は、 Child A: $18.0 \%$; Child B: $22.1 \%$ : Child C: $35.0 \%$ と、肝機 能が低下するにしたがって有意に増加した。周術期の PSP尿中排泄率は、術前: $20.4 \%$,術後3日目: $19.2 \%, 7$ 日 目: $15.8 \%, 14$ 日目: $15.4 \%$ と、周術期に有意な変化を認 めなかった。術後合併症との相関では、全合併症とは 相関を認めなかったが、感染症性合併症の有無では、 術後3日目のPSP尿中排泄率は合併症有群 (27.3\%) で 無群（17.4\%）に比し有意に高値であった。【まとめ】 PSP経口負荷試験は周術期における腸透過性元進の判 定およびBTL発生の予知に有用と考えられた。

\section{I-210副腎偶発腫瘍24例の臨床病理学的検討}

兵庫県立成人病センター外科, 同泌尿器科*

金田邦彦, 中山剛之, 林 俊, 和田哲成, 前川陽子, 河村 貴, 寒原芳浩, 佐古田洋子, 河野範男,

中谷正史, 石川羊男, 藤井昭男 ${ }^{*}$

[目的］当センターで経験した副腎偶発腫瘍24例に対

する診断契機, 方法及び治療について臨床病理学的検 討を加えたので報告する。

[対象および結果］1985-1996年の12年間に経験した 副腎偶発腫瘍24例を対象とした。24例の内訳は男性 15例，女性9例で年齢は37-71歳であった。発見の契機 は健康診断で見つかった症例が7例, 他疾患の精査中 偶然発見された症例が17例であった。発見方法はCT 14例，US 7例，MRI 1例で，24例のうち22例に手術

（経腹的副腎摘出術）を施行した。病理組織学的には Nonfunctioning cortical adenoma 13例, Functioning adenoma 5例, その他（hyperplasia, TB, cyst 等） 5例 でいずれも良性腫瘍で悪性例は認めなかった。

[結論] 今回の検討では悪性例は認められなかったが 副腎偶発悪性腫瘍の報告例もあること，また自験例の ようにホルモン活性のある副腎偶発腫瘍が存在するこ とから、副腎偶発腫瘍に対しては積極的な外科治療を すべきであると考えられた。
I -211直腸癌を合併していた 巨大な後腹膜 cellular neurilemoma（神経鞘腫）の 1 例 岩国市医療センタ一医師会病院外科

佐伯俊宏, 多田耕輔, 足立 涅, 内山哲史, 村上卓夫 比較的稀でかつ巨大な cellular neurilemoma の 1 例を 経験したので、その組織学的特幑も含めて報告する。 症例は72歳の女性で、約8年前梳右方にピンポン玉 大の無痛性腫瘤があるのに気付き、徐々に増大するた め、平成7年6月9日近医受診し、小児頭大の腹部腫瘤 を指摘され、精查加療のため当院に入院した。諸検査 の結果、後腹膜の多房性腫場と判明したが、確定診断 がつかず手術を施行した。なお、術前の大腸透視検査 で直腸癌を認めた。7月10日、後腹膜腫瘍摘出、胆摘、 門脈・総胆管合併切除を行い、その1力月後に低位前方 切除を施行した。摘出した後腹膜腫場は長径 $26 \mathrm{~cm}$ 、重 量3082 gで、病理組織学的には、Schwann cell 由来で、 紡錐形細胞が密に束状あるいは波紋状をなして増殖し ており、核の大小不同はかなり強く巨大なものも混在 していたが、核分裂は非常に少なく、辺縁は硝子化や 石灰化した被膜で顠われていた。免疫染色にてS-100 蛋白陽性で、cellular neurilemomaと診断された。直腸 癌はRsRa、1型、中分化型腺癌、mp、n1(+)、stage III a、 cur Aであった。術後経過は順調で、術後7力月現在再発 の兆候を認めず、外来通院中である。

\section{I - 212 後腹膜脂肪肉腫の5例}

岡山赤十字病院外科, 同病理 ${ }^{*}$

池田英二, 小野監作, 湯浅一郎, 小西寿一郎, 内藤 稔, 森山重治, 辻 尚志, 古谷四郎, 名和清人, 大 塚康吉, 國友忠義*

[目的］後腹膜悪性腫瘍中, 最も頻度が高く局所再 発し易い脂肪肉腫について, 再発に対する治療や補助 療法の効果につき, 予後の点から臨床的検討を加えた。

[方法] 当院で手術を行った後腹膜脂肪肉腫症例 5 例 の年令, 性, 初発症状, 手術回数, 合併切除臓器, 補 助療法, 組織型, 予後などについて検討した。 [成績] 年令は41歳から68歳（平均57歳）で全例女性。症状 は腹部膨隆 3 例, 腹部腫瘤触知 2 例であった。多い例に は5回の手術を行い，5例に対して延べ13回の手術を行っ た。3例に対して腸, 腎臓など周囲臓器の合併切除を 行い，再手術で合併切除が必要となる傾向がみられた。 2例に化学療法を 3 例に放射線照射（延べ5回）を併用 したが有効ではなかった。組織型は高分化型4例，粘 液型1例であった。初回手術後, 最高15年生存してお り, 現在全例生存中である。[結論］1）後腹膜脂肪 肉腫5例を検討した。2）局所再発を繰り返す傾向が認 められ, 化学療法や放射線照射などは有効ではなかっ た。3）再発に対して, 周囲蔵器の合併切除を必要と するが, 再手術により長期生存が得られた。 
I - 213腸間膜囊腫との鑑別が困難であった腸間 膜結核性リンパ節炎の1 例

協立総合病院外科 ${ }^{1 !}$ 名古屋大学分院外科 ${ }^{2}$

中沢幸久 原春久 ${ }^{1}$ 安藤久實 ${ }^{2}$

消化管 ·肺病変を伴わない腸間膜結核性リンパ節炎 の 1 例を経験し、術前画像診断上腸間膜囊腫との鑑別 が困難であったので報告する。【症例】24歳女性〔現 病歴]2ケ月前から発熱が続き、腹痛も出現するため、 精査目的入院〔検査所見〕 WBC $5300 \mathrm{Hb} 11.4 \mathrm{CRP}$ $5.6 \mathrm{HBs}$ Ag $(+)$ CEA $1.0 \mathrm{ng} / \mathrm{ml}$ CA19-9 22U/ml $\mathrm{CA} 12544 \mathrm{U} / \mathrm{ml}$, 胸部X線写真：異常なし。腹部USに

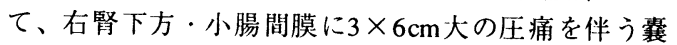
胞様腫瘤を認めた。同部位は造影CTでは周囲High中 心Low、MRIでは、T1-低、T2-低〜等信号であった。 アンギオでは回結腸動静脈の不整压排を認めた。〔経 過 ·手術所見了感染を伴う腸間膜囊腫と診断し、抗生 剂投与後、待期的に摘出術を行った。腫瘤は2つ存在 し、备々 $55 \times 37 、 24 \times 18 \mathrm{~mm}$ 、病理診断は結核性炎注 で、㭘体のGaffkyは陽性で、組織でも結核菌が証明さ れた。な㧍術中に小腸・大腸は異常なかった。術後3 日目に行ったツベルクリン反応は強陽性であった。 腸・肺病変を認女ない腸間膜結核性りンバ節炎は稀で あり、慗腫との鑑別が困難であったので報告する。

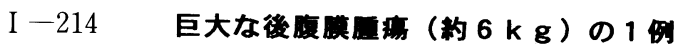

東北大学第 2 外科 ${ }^{11}$ 同第 2 病理 ${ }^{2)}$

八巻 英郎 ${ }^{11}$, 標葉 隆三郎, 赤石 隆, 阿部 啓 二, 矢野 英史, 殿塚 規雄, 西平 哲郎, 里見 進 笹野 公伸 ${ }^{2)}$

約 $6 \mathrm{k} \mathrm{g}$ にも達する巨大な後腹膜腫場を経験したの で病理学的考察を加えて報告する.

症例は 65 才女性, 1995 年 10 月右脳内出血で 他院に入院したさい巨大な腹部腫瘤を指摘され手術目 的に当科紹介となった. 特に自覚症状は認めなかっ た. C T, MR I で肝蔵直下から仙骨レベルまでほぼ 腹腔全域を占拠する脂肪を主成分とすると思われる腫 瘤で腸管を左方に圧排していることから右後腹膜原発 腫瘍と診断された. 96 年 1 月摘出手術施行した. 腫 瘍は大部分は脂肪からなるり $43 \times 34 X 10 \mathrm{~cm}$, 重量は 5. $9 \mathrm{k} \mathrm{g}$ であり周辺荗器との瘑着は強固でなく比較 的容易に摘出しえたが, 中心部に硬く厚い非常に凹凸 の強い壁による襄胞性病変を有しliposarcomaが疑われ た. 病理組織では大部分が異型性のない脂肪組織であ ったが震胞壁部分に壊死像や豊富な有糸分裂像が認め られ悪性腫場であることが示唆された. しかし同部位 の脂肪染色は陰性であり, S-100陰性, $\alpha$-S M A 陰 性であることからfibrosarcomaと診断された.
I -215

睡の工例

診断が困難であった横隔膜原発横紋筋肉

大车田市立釉合病院外科, 同病理 ${ }^{*}$

末吉 晋, 前村智之, 池田純啓, 廣松伸一, 菅 記博, 志田誠一郎, 田尻鉄郎, 福島 駿, 荒川正博*

横隔膜原発横紋筋肉腫は非常に稀である. 今回我々 は, 診断に苦慮し半年の経過の後剖検にて横隔膜原発 横紋筋肉腫と診断された 1 例を経験したので報告する.

症例は 76 歳女性, 平成 7 年 7 月 9 日右悸肋部痛出現し 当院内科入院となる. C T で右横隔膜下に低吸収領域 を認め炎症反応陽性であったため横隔膜下膿湯の診断 で治療が開始された．抗生物質投与にて一時的には症 状の改善が認められたが, 病変の拡大を認めたため外 科紹介となる. 肝臓や横隔膜原発の腫湯も疑い 10 月 19 日試験開腹をおてなうと, 肝臓と横隔膜は痈痕様 組織で癋着しており，ての組織と肝藏の睡場を一部摘 出した。病理では広範な燷死組織の中に悪性を疑わせ る睡塲細胞の増殖, 浸潤を認め肉腫と診断されたが, 特染でも詳細な分類も原発巣も確診にいたらなかった。 2 力月後の病理解剖では右横隔膜から肝蔵一一壊となっ た腫㰾を認め, 腹腔内・両側胸腔内・心震内に播睡を 認めた。電影所見等も考慮し最終的には横隔膜原発横 紋筋肉腫と診断された。

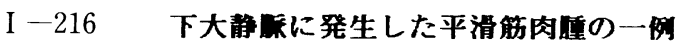

北九州市立医療セン夕一外科 ${ }^{1)} \cdot$ 内科 $^{2 \text { ) }} \cdot$ 病理 $^{3}$;

放射線科 ${ }^{4)}$

三原章一1）西原一善 中原昌作 武田成彰

安部隆二 吉田浩樹 ${ }^{2}$ 豊島里志 ${ }^{3)}$ 小野秢 4 )

【症例】60歳 女性、腹痛を主訴江来院。

【検查所見】US、C T、M R I にて、蓃頭部背側 大動脈前面に $4 \mathrm{c} \mathrm{m}$ 大の腫瘤を認め、血管造影にて 左督静脈の閉塞、側副血行路の形成を諗めな。CE.

1.9ng/ml、C A 19-9 1.6U/mlと正常範囲であった。

【術中所見】後腹膜腫癌、他癌の大動脈リンパ節転移 の疑いにて開腹。腫崵は下大静脈の左督静脈合流部に 発生しており、下大静脈、左觜静脈の一部を巻き込み 下大静脈との剥離は困難であった。下大静脈の一部と 左督静脈を含んで腫瘍を摘出した。

【病理組織診断】平滑筋肉腫で、下大静脈壁から発生 し管内性の発育を示していた。

【転䚻】術後経過良好で、7 カ月たった現在も転移、 再発は認められていない。

【結語】下大静脈原発の平滑筋肉腫法極めて稀な疾患 で本邦で約 40 例の報告しかないか、、大静暚近穷心 発生した後腹膜腫瘤を認めた場合に注平滑筋肉腫を鑑 別診断の一つに入れるべきであると考えられた。 
I -217虫垂炎穿孔による腹膜炎に合併した Fournier 症候群の 1 例

\section{社会保険小倉記念病院 外科}

阿部好弘, 矢原昇, 菅野元喜, 坂田晃一朗, 東山洋 岡本亮爾, 福山訓生

[症例] 11 歳の男児。煰吐、下痢症状にて発症。次 第に発熱、陰囊の腫脹ををたしたため、当院を紹介。 右下腹部から陰䨢にかけて著明な発赤と腫脹、また腹 部には圧痛と筋性防御を認めた。

[手術所見]筋膜、腹膜前一陰震にかけて膿の貯留を 認め、虫垂の壊死穿孔を認めた。膿性腹水の細菌培養 結果杜 E.coli が少数、 $\alpha$-streptococcus $3+$, Bacterides 3+，他嫌気性菌を認めた。

〔経過〕術後、意識レベルの低下、低カルシウム血症 低酸素血症、胸水の貯留を認めた。39 C 前後の発熱 が続さ、陰塞の皮膚および腹部の皮膚の壊死が進行。 皮下組織、筋膜は壊死溶解し、その範囲は正常皮下 で広がった。CT検查で左胸腔内、左右後腹膜、の膿 瘍を認め、第 15 病日に手術（ドレナージ、デブリー ドメント、右除睪術）を施行。その後さらにMesh 植皮術、ドレナージ術を施行し、救命でをた。

[まとめ] Fournier 症候群は死亡率の高い疾患であり、 早期の診断とデブリードメントが重要と思われた。

$\mathrm{I}-218$ 小腸腸問膜線維烥症の一例

県立広島病院第一外科

大石幸一 木村まり 大城望史 角舎学行 藤本伸司 札場保宏 板本敏行 石川哲大 田中一誠山本泰次 大城久司

[目的］小腸腸間膜線維腫症の一例を報告する。

[症例] 60 才男性、主訴は上腹部痛。画像検査で空 腸の平滑筋腫瘍之診断、手術施行。十二指腸及び空腸 を巻き込んだ腫㾿性病変を認め、同部位の部分切除を 施行した。病理検査では分化した線維芽細胞と膠原線 維の增生がみられ、悪性所見を認めず、腸間膜原発の 線維腫症と診断された。現在再発の徴候はまだない。

[考察] 線維腫症とは良性線維性組織の過形成を示し、 デスモイドと呼ばれる。腸間膜にはまれであるが、腸 間膜原発腫瘍の中では比較的多い。腸間膜線維腫症の 本邦報告例は 32 例で、主な症状は腹部腫瘤、腹部膨 满感であった。術前診断は困難であるが、家族性ポリ ポーシスに合併したり、手術の既往、妊娠などホルモ ン量の変化が誘因となる特徵がある。治療は外科的な 切除であるが、しばしば再発、覀性化、死亡例もあり、 注意深い経過観察が必要と思われる。

[結語］（1）小腸腸間膜に発生した線維腫症の一例 を経験したので報告する。（2）本症例は再発の可能 性もあり、注意深い経過観察が必要と思われた。
I -219脾動脈及び肝動脈に多発した腹部内䐪

動脈瘤の 1 例

六甲病院外科

瀬戸本悟、中村順兒、木全博己、住吉孝雄 瀬藤晃一

症例は 46 歳の女性、平成 5 年 10 月会社の検診にて膵

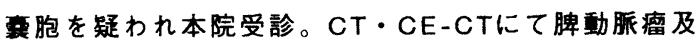
び総肝動症㿔と診断、腹部血管造影検査を施行した。 脾動脈には脾門部までに最大 $3.7 \mathrm{~cm}$ 、計 3 個の動脈瘾 が存在した。総肝動脈は上腸間膜動脈より分岐してお り胃十二指腸動脈との分岐部に径 $2 \mathrm{~cm}$ の動脈痹が、 また䡒十二指晹動脈末梢側にも小さな動脈㾴が存在し た。患者は無症状であったが、動脈癐が巨大で破裂の 危険性があるため平成 6 年 1 月10日手術を施行した。 左罥動脈分岐直後で脾動脈を結紫切離し動脈㿔を含め 脾門部まで切除、脾摘も行った。肝動脈痹は罥十二指 晹動脈、左右肝動脈をそれぞれ結紫切離し摘出、そし て右肝動眽と左罥動脈を伆合し血行再建した。

以上、腹部内蕾動脈に多発した動脈瘤の 1 例を経験し たので文献的考察を加え報告する。

I -2205 重複癌（膀胱癌、大腸癌、前立腺癌、

肺癌、胃癌）の 1 症例

聖路加国際病院 外科 ${ }^{11}$ 同 病理 ${ }^{21}$

伊藤幹人 ${ }^{12}$ 、大東誠司、阿部恒平、諏訪勝化、 座波久光、耕濑信太郎、西尾用接、桜井健司、 植草利公 2 、斉木茂樹

症例は80歳男性。過去 22 年間に 4 澸器に発生した重 複痹に、新たに胃癌の発症をみた 5 重複癌の 1 症例を 経験したので報告する。既往歴としては1973年、膀腃 癌のため他院で膀胱部分切除術が施行された。1990年 上行結腸痹に対して右半結腸切除術を施行した。以降 は当院で経過䚁察を行っており、1993年より排尿困雉 で診断された前立腺癌に対してホルモン療法を施行し ている。1995年 1 月、前立腺癌の経過観察を目的に行 った胸部 X線写真で右肺上葉の肺癌が発見され、右肺 上葉切除術を施行した。今回1995年10月、腹部不快感 を主訴に行った胃内視鏡で早期胃癌と診断され、胃亜 全摘術を施行した。病巣は三箇所であり、幽門部にII $18 \times 12 \mathrm{~mm}$ well differenciated adenocarcinoma sm $\mathrm{n}_{0} \mathrm{H}_{0} \mathrm{P}_{0} ;$ stage I。、他の 2 つは胃体部後壁及び胃体 下部にありいずれも II $\mathrm{c}$ well differenciated adenocarcinoma 深達度mであった。これらの病巣は連続性 はなく胃の多重癌であった。 5 重複癌は本邦で過去10 年間に 4 例と稀な症例であるため報告した。 


\section{I - 221 急性腸間膜動脈閉塞症9例の検討}

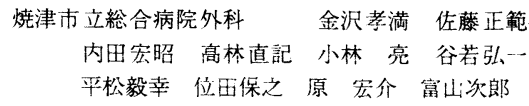
われわれは、1984年から95年に経験した9例につい て検討したので報告する、既往歴として循環器系合併 症 5 例 $(55.6 \%)$ 症状は軽度圧痛から板状硬,shockまで 様々であり、術前に本症と診断しえたものは2例と診断 の難しさをうかがわせた。手術は試験開腹が 4 例で、こ れらはSMAのみならず、CeliacやIMAにも閉塞をきたし 腸管が広範囲にわたり壊死に宿った症例であった。3例 が術後 36 時間以内に死亡し生存は 2 例のみである。検査 データは、絞扼性イレウスにて腸切除した14例と比較 するとLDHのみが本症において有意に高かった。次に 症例を呈示する。症例は69歳男性 心筋梗塞の既往あ り。腹痛、嘔吐より発症。症状は典型的な急性虫垂炎 であったが、小腸全体に色調が悪くSMAの拍動を触れ なかったが壊死には宿っておらず腸切除せず閉腹 SMAより Urokinase注入したが効果なく、全身的な抗凝 固療法開始したが腹部症状は軽快していった。貧血、 低蛋白血症があり1-gultamine投与。著明に改善し4ケ月 後退院。本症は、非常に致死率の高い疾患であるが術 後早期に死亡する例は対応が遅れ、壊死が広範囲に進 行した症例である。早期診断、治療が重要である。

I -222 Female adnexal tumor of probably wolffian origin(FATW0)の 1 例

八尾徳洲会病院外科

上野力敏、岡田廣

症例：64葴、女性。下腹部痛を主訴に来院。C T ・ エコー・M R I で骨盤左側で子宮と直腸の間に充実性 腫痀、注腸で直腸の浸潤像、血管造影で左骨盤に腫癌 血管を認めた。手術：H 5年 12 月 22 日。左子宮広間 膜に、黄色粗雑で境界不明瞭な腫癌が所々唗死に陥り

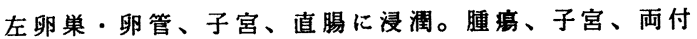
属器、直腸切除。低位前方切除術で再建。病理: 左 子宮広間膜と左卵巣門に腺腔形成、乳頭状構造を示す 腫瘍細胞增殖。FATWOで腺癌と診断。術後経過: 術 後 2 年目に大動脈周囲リンパ節、骨盤リンパ節に転移 を認め、5-FU、シスプラチン、ロイコボリンで治療。 大動脈周囲リンパ節消失、骨盤リンパ節縮小した。 考察：W01ff 管は中堅由来で、男性生殖器を形成する が、女性では生後 3 ヶ月で消退。卵巣上体、卵单旁体 を残すに過ぎい。FATW0 は KarimenejadとScullyが 1973 年に報告して以来、ChayaJ.Prasad らによると世 界で40例の文献報告のみで非常に稀である。治療、予 後に関しては症例が少なくはっきりせず。軽度悪性の 報告が多いが、転移再発の報告すある。
I - 223 食道癌周術期管理におけるステロイド投与 の基礎的検討一開胸開腹ラットモデルを用いて一

慶應義塾大学外科 ${ }^{1)}$, 同救急部 ${ }^{21}$

中村榮一"1), 安藤暢敏 ${ }^{1)}$, 小澤壯治 ${ }^{1)}$, 石 志紘 ${ }^{1)}$,

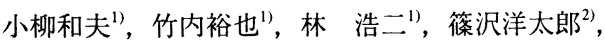
上田政和 ${ }^{1)}$, 北島政樹 ${ }^{1)}$

食道癌周術期管理におけるステロイドの至適投与時 期と至適投与量について開胸開腹ラットモデルを用い て検討した，1)手術モデル：雄性Wistar系ラットをコ ントロール群 (C群), 開腹群 (L群), 開胸群 (T群) および開胸開腹(TL)群に分けた. 血清IL-8はC 群, L 群, T群, TL群の順に加刀後6時間目のピーク值が高くなっ た．2)メチルプレドニゾロン（MP）投与モデル：開 胸開腹モデルおいてMPを加刀 2 時間前〜1時間後に投 与すると, 加刀直前投与で血清と胸腔洗浄液中のIL-8 が最も抑制された．MPを3〜 100 $\mathrm{mg} / \mathrm{kg}$ 投与すると，血 清と胸腔洗浄液中のIL-8は $10 \mathrm{mg} / \mathrm{kg}$ から抑制され，血 清IL-8は $10 \mathrm{mg} / \mathrm{kg}$ 以上で差がみられなかった.

開胸開腹侵襲により惹起される著明な気管支肺炎像は MP投与により軽度になった. IL-8の変動からみると MPの至適投与時期は加刀直前, 至適投与量は $10 \mathrm{mg} / \mathrm{kg}$ と考えられ，この投与法により肺組織の好中球浸潤が 抑制された。

\section{I - 224 ラット出血性ショックに対する} gal actose-liposomal PGE1の有効性

浜松医科大学第 2 外科

芹澤 淳、中村 達、鈴木昌八、坂口孝宣、

石田秀樹、落合秀人、今野弘之、馬塲正三

<目的>PGE1を肝指向性の高いgalactose-

liposome(Gal-Lip)で封入してラット出血性ショックモ デルに投与し、その有効性を検討した。

<方法 >Wistar ratを用い、脱血により平均動脈圧を $40 \pm 5 \mathrm{mmHg}$ で60分間維持後蘇生させるショックモデ ルを作成した。脱血前にPGE1として $0.5 \mathrm{mg} / \mathrm{kg} / \mathrm{min}$ 30分間投与するLPG群と、対照として生食を投与する NS群の 2 群を作成し、7 日間生存率、蘇生後 1 時間の 平均動脈圧、門脈圧、肝組織血流、蘇生後9時間まで の血清GOT、BUN、クレアチニン、TNF $\alpha$ 濃度を測定 した。

く結果及び考察 >NS群に比較して、LPG群では蘇生 後の肝組織血流、血清GOT、BUN、クレアチニン值、 生存率が改善した。LPG群ではサイトカインネットワ 一クのキーメデイエーターである TNF $\alpha$ の蘇生後早期 の増加も抑制されており、Gal-Lip封入PGE1投与の有 効性の一つの要因と考えられた。 
I - 225 LPS投与下の好中球機能は食餌性 核酸欠乏によって変化するか？

神戸大学第一外科

平井昭博、宇佐美真、北村有子、磯 篤典、 小谷穣治、曹 遠明、笠原 宏、斎藤洋一

[背景㧍よび目的]ヌクレオシドはsalvage合成 されるために、その投与が検討されていなかっ たが、近年、各種免疫能に及ほす寸影響が報告さ れている。そこで食餌性核酸欠乏マウスを用い てLPS投与下の好中球(PMNs)の機能変化とその 病態を検討した。[方法] 1 週間の食餌条件にて 普通食群(C群)、核酸欠乏食群(NF群)を作成した。 末梢血PMNsの1)FITC-LPSの取り込み能、2)接 着因子(Mac-1 / LFA-1)の発現、3)活性酸素産生 能をflow cytometryで測定した。また、 $25 \mathrm{mg} / \mathrm{kg}$ のLPSを腹腔内投与し、4)肺へのPMNsの集積と 肺胞内出血を組織像より比較し、5)72時間生存 率をみた。[結果]LPS取り込み能、接着因子の発 現、活性酸素産生能はNF群で有意に低下した $(\mathrm{P}<0.05)$ 。また肺へのPMNsの集積と肺胞内出血 はNF群で軽減し、生存率はNFで改善された。 [結語]食餌性核酸欠乏下ではPMNs機能は抑制さ れ、LPS投与後の臓器障害が軽減される。

I一-226 ラット肝虚血一再灌流障害における組織因

子 ( T F ) の経時的変化に関する検討

京都府立医大第二外科

小林義典，吉村了勇，山岸久一，岡隆宏

[目的]組较因子(Tissue Factor, TF) は通常血管を構 成する哉維芽細胞や平滑筋細胞の膜表面に常在する膜 タンパクであり、炎症反応や免疫応答に伴う細胞刺做 によってマクロファージ・血管内皮細胞上に発現誘導 される。ラット肝虚血一再灌流モテルにおける肝組織 中の $\mathrm{T} \mathrm{F}$ 活性及び $\mathrm{T} \mathrm{F}$ 発現を検討した。 [方法]ラッ 卜肝動脈・門脈・胆管の左葉枝、尾状葉枝をクランプ （ $70 \%$ 部分肝温阻血）120 分後テクランプし再灌 流した。経時的に㬢牲死させ血夜, 肝組織を採取した 。[結果] T N F , G P T, ヒアウロン酸, P T, T $\mathrm{A} \mathrm{T}$ は再灌流後 $3 \sim 5$ 時間でピークに達した。血中 $\mathrm{T}$ $\mathrm{F}$ 活性は再灌流後 3 時間でピークに達しその後低下、 12 時間で虚血前值に復したが、虚血肝組織中の T F 活性は再灌流後 12 時間で上界した。肝壤死巣は 5 時 間後より経時的に增大し $\mathrm{T} \mathrm{F}$ は免疫組幽染色上同塿死 单内に著明に発現した。[結語] 血中 T F は肝細胞障 害ないしは内皮細胞障害を反映していた。 $\mathrm{T} F$ は肝垻 死巣に訸導発現され温虚血一再灌流障害後の細胞猿死 形成に梁く関与している事が示唆された。
I - 227胃癌手術後の顆粒球動態についての検討

順天堂大学医学部第 1 外科

渡辺英章、西村和彦、岡原仁志、高田 丈、椭原宣 （目的）手術後の顆粒球增加は侵皛に対する生体の合 目的な反俯であると考えられるが、一方、顆粒球の産 生する活性酸素は組轿障害性を有する。また、術後の systemic inframatory response syndromeは、頪粒球 機能の亢進が関与すると考えられている。そこて、顆 粒球動態に手術侵祳の与える影辢について梌討した。 （方法）胃癌手術例について、術前後の末梢白血球数、 顆粒球数を計数、顆粒球サブセットをFACSで解析、血 中 G-CSF、M-CSF浱度をELISA法で、末柏白血球のG-CSF mRNAの発現をNorthern Blottingで検討した。（結果） 白血球、顆粒球は術直後より增加、第 1 病日がピーク となった。G-CSF壊度は術直後よりいちじるしく上昇、 第 1 病日がピークとなった。術直後の白血球、䫐粒球 の增加率とG-CSF源度上昗率は正の相関を示した。M-C SF浱度は第 2 病日にピークを示した。術直㣪、G-CSFレ セプター陧性顆粒球は娍少、CD64陽性顆粒球が末梢血 中に瑟められた。末梢白血球にG-CSF घ-RNAの発現は認 められなかった。（考察）手術侵裴後の末㭘血中の顆 粒球增加は、侵祳によってG-CSF産性が惹起され、骨䬼 から顆粒球が動員されるためと考えられた。

I一228 仆力仢及び SIRS 項目からみた手術侵襲 軽減目的での術中 protease inhibitor 投与の意義に関 する検討

防衛医科大学校第 1 外科

小野 聡、青笹季文、長田俊一、木下 学、冨松聡一 大草 康、上藤和彦、市倉 隆、望月英隆、玉熊正悦 Major 手術侵襲における尘仆仿やSIRS 診断項目の変 動に及ぼす protease inhibitor(PI)の影響を, PIの種類, 投 与開始時期を中心に検討した。【方法/結果】検討 $1: \mathrm{T}$ NF $\alpha$ で血管内皮細胞を刺激した際の PAI-1 活性発現 に対する各種PIでの阻止効果を比較すると, gabexate $\mathrm{m}$ esilate(GM)が最も顕著であった。検討 $2: P I$ 投与開始時 期を検討するため食道切除術 (E群) 5 例, 胃全摘術 ( T群) 5 例を対象に術前, 術中 2 時間毎, 術後の血中 IL-6,IL-1r $\mathrm{a}$ を測定したところ, E群では手術開始4時間後からサ仆 カイ亻の上昇がみられた。検討 $3: \mathrm{E}$ 群 10 , T群10例を術後か らGM投与を行った群各5例と, 麻酔導入時から GM投与を 開始したGM群各5例に分け, 術後の开仆价及び SIRS 項 目を比較すると, E群ではGM群が血中 $\mathrm{IL}-6$ 值, 脈拍, 呼 吸数は有意に低值で推移した。尚T群では両群間に差を 認めなかった。【結語】食道癌手術では手術開始6時 間後には既に高专仆侠血症が見られるため,麻酔導入 時から GM投与を開始することによって IL-6の過剩産 生を抑制し, 術後 SIRS からの早期離脱効果がみられた。 
I -229 外科的侵噈に対する Biopyrrins（ビリ ルビン酸化生成物）の生理的意義 埼玉医科大学第二外科” 東京医科歯科大学難治疾患研 究所选伝生化学教室 ${ }^{2}$

岡村維摩" 、寺角匡弘、青木一真、竹内浩紀、 辻 美隆、村上三郎、里見 昭、石田 清、平山廉三、 山口登喜夫 ${ }^{2)}$ 、中島 熙

[はじめに] 従来よりビリルビンは antioxidant とし ての生理的作用が報告されている。我々は酸化的スト レスが高度であった外科手術後の特定の患者において、 尿中にジアゾ法では測定し得ないビリルビン関連物質 の增加を、我々が開発した抗ビリルビン単クローン抗 体（2 4G7）を用いた ELISA 法によって見い出した。 更にこの関連物質がビリルビン酸化生成物であること をも確認し、biopyrrins 之命名した。そこで、入院 患者の術前後の尿中 biopyrrins 值を測定し、外科的 侵襲を含む生体的ストレスとの関連性について検討し た。

[結果および考察] 尿中 biopyrrins 值は重症患者の 中でも特にSIRS の状態である患者においてのみ有意 に高值を示した。よって尿中 biopyrrins は SIRS の 指標となりうるものと思われた。更に尿中 biopyrrins 值が SIRS から MOF への移行の判定に応 用できる可能性が示唆された。

I - 230 切除脺に対する経ロプロテアーゼインヒビ ターの栄養効果, とくに休薬後の効果持続性について

山口大学第二外科

白神利明,西原謙二,丹黒 章,岡 正朗,鈴木 敞

【目的】プロテアーゼインヒビター(PI)の 経口投与 により惹起された膵栄養効果の投与中止後の効果持続 性について,切除膵と非切除聯を対象に比較検討した。

【方法】7週齢Wistar系雄性ラットを以下の 4 群に分け た.単開腹群: 単開腹+蒸留水投与,単開腹PI群: 単開腹 + PI投与,膵切群:膵切除+蒸留水投与,膵切PI群:膵切除+ PI投与.胹切除はsplenicおよびgastric segmentを切除 し,PIはメシル酸カモスタットを $200 \mathrm{mg} / \mathrm{kg}$ で術後第7 病日より連日7日間,強制胃内投与し, 以後休薬した。 PI投与前,投与終了時,休薬後 1 週, 2 週, 4 週に屠殺し,膵 湿重量,蛋白含量,DNA含量を測定し比較するとともに, 光顕的に検討した.【結果】膵湿重量と蛋白含量はPI 投与により有意に増加し,それは膵切PI群で顕著であ った.PI投与終了後は単開腹PI群は急速に減少したが, 聯切PI群では高値が持続した.光顕的には羘重量の増 加と一致して荤腺房細胞の肥大がみられた.【まとめ】 PI投与による膵栄盖効果は非切除苇では一過性であり

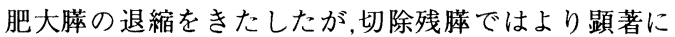
発現し長期間持続し,残滕の再生を促進した。
$\mathrm{I}-231$ 膵胃吻合再建によるPpPD術後の残膵の形 態学的及び生理学的検討

名古屋大学第 2 外科

細野二郎、中尾昭公、金子哲也、野本周嗣、

奥田直人、石川俊通、原田明生、野浪敏明、高木 弘

【目的】橧胃吻合再建によるPpPD術後の残膡を,形態 及び生理学的観点から検討した。【方法】対象は膵胃吻 合再建PPPD12例。形態評価としてERP,EUSを施行。機能 検査としてPFD、糖負荷試験を施行。胃内 $\mathrm{pH}$ を24時間連 続測定し,さらに胃液中脞䣼素活性を測定した。【結果】 EUSでは全例で残膵の性状確認が可能で,最大粨管径は術 前後で有意な変化は無かった。ERPでは、セクレチン投 与にて膵液分泌が確認されたのは $4 / 12$ 例,粸管造影が可能 であったのは $3 / 12$ 例であった。PFD 值では術後の方が低 い傾向が見られたが,耐糖能では術前後で有意な変化は認 めなかった。胃液検查ではpH4以上に上年する食後や就 眠時では, 1 例を除いて䣼素活性の上年を認めた。【結論】 今回直接的に膵管の開存が確認されたのは12例中4例に過 ぎなかったが,膵管径の比較,胃内膆䣼素活性の検討から, 殆どの症例で膡管の開存性が証明された。また㬸機能で は,内分泌機能は維持され,外分泌機能は若干の低下が見 られたが,これには胃内pHの影響もあると考えられた。

I - 232
の試み

千葉大学第二外科

望月亮祐、岡住慎一、吉田雅博、高山 亘、福長 徹、 井奥昇志、大月和宣、三浦文彦、矢野嘉政、首藤潔彦、 青山博道、篠藤浩一、松崎弘志、磯野可一

(目的) ${ }^{11} \mathrm{C}$-Methionineをtracer として用いたpositoron emission tomography（以下 Met-PET）による桠機能評 価を試み、膵手術例の術後膵機能評価に応用した。

（方法）非手術例21例（正常膵15例、慢性脺炎6例）、 膵切除例 9 例、膵管空腸吻合術施行例1例にMet-PET を 施行し、 ${ }^{11}$ C-Methionineの膵集積度をdifferential absorption rasio（DAR）を用いて評価した。

（成績）非手術例では膵集積度において、慢性膵炎は 正常膵に比し危険率1\%にて有意に低値であった。膵 切除例における術後残膵の集積度の検討では、脺頭十 二指腸切除例7例では平均で術前の $21.9 \%$ まで低下し たのに対し、膵体尾部切除例1例では術前の $65.5 \%$ 、 膵体部切除例1例では荤頭部、脞尾部でそれぞれ術前 の $64.1 \%$ および128.3\%であった。腪管空腸吻合術施 行例1例では術後腪集積度は変化しなかった。

（結論）Met-PET による部分㬸機能評価の可能性が示 唆され、膵手術例への応用が考えられた。 
I - 233幽門輪温存膵頭十二指腸切除術(PpPD)後 の膵内分泌機能の解析 : インスリン分泌刺激ホルモン Glucagon-like Peptide-1(GLP-1)の意義

福岡大学第 1 外科 ${ }^{1)}$,第 1 生化学 ${ }^{2}$, 臨床検査医学 ${ }^{3)}$ 廣吉元正"), 安波洋一"), 立石力ヨ子 ${ }^{21}$, 松岡雄治 ${ }^{2}$, 小野順子 ${ }^{3)}$, 真栄城兼清 ${ }^{11}$, 岡本 潔1, 笠普一朗", 宮崎 亮'), 池田靖洋 ${ }^{11}$

インスリン分泌刺激ホルモン、GLP-1のPpPD前後の 推移と、耐糖能との関連性を検討した。[方法]最近 2 年半のPpPD症例 : 15例(糖尿病型 : 6 例,境界型 : 9 例) を対象とし、術前後に75g経口糖負荷試験(OGTT)を施 行した。[結果]術前境界型の 9 例は、術後も 6 例が境 界型で, 2 例が糖尿病型, 1 例が正常型となった。一方、 術前糖尿病型の 6 例は、術後も 4 例が糖尿病型で、境 界型、正常型が各 1 例となった。血清インスリンおよ びグルカゴン值は、糖尿病型と境界型ともに術前後で 有意差を認めなかった。境界型の血漿GLP-1値は、グ ルコース負荷後 $30,60,90,120,180$ 分および各時間の 総和( $\Sigma$ GLP-1)で術後有意に上昇した。一方糖尿病型 は各時間ごとの比較では有意差はなく、 後有意に上昇していた。[結語]PpPD前後で、インスリ ン,グルカゴン值に有意差はなかったが、GLP-1値は術 後有意に上昇していた。GLP-1は膵切除後の耐糖能の 推移を示す新たな指標となる可能性が示唆された。

I-234 Osler-Rendu-Weber病に合併した 膵頭部動静脈庭の一例

県立広島病院第一外科 ${ }^{11}$ 、広島大学医学部第二外科 ${ }^{2}$ 木村まり" 岡田和郎、丹治秀裕、杉野圭三、田中恒夫 丸林誠二、八幡浩、浅原利正、福田康彦、土肥雪彦 ${ }^{2)}$

[目的] Osler-Rendu-Weber病に合併した膵頭部の 動静脈㾝の一例を経験したので、報告する。

[症例］63才の女性。主訴は上腹部痛。近医で十二 指腸潰湟、膵頭部腫瘤、肝硬変指摘され紹介となる。 腹部血管造影で膵頭部に動静脈瘦、食道胃静脈瘤あり。 顔面、口腔、両指尖に紅斑、生検で遺伝性毛細血管拡 張症のOsler-Rendu-Weber病と診断。動静脈痩によ る虚血及び圧迫で十二指腸潰場を生じ、動静脈シャン トで門脈圧六進症が増悪したと考え、膵頭十二指腸切 除を予定したが、全身状態不良のため、胆脾摘、胃十 二指腸動脈結禁のみ施行。門脈圧の下降及び後日精査 で動静脈瘦の縮小、食道静脈瘤の改善を認めた。

[考察] Osler-Rendu-Weber病は常染色体優性遺伝 性で、皮膚、結膜、内臓諸臓器の毛細血管が菲薄化し、 粘膜の出血を反復する。血管形成異常として動静脈瘦 が肺、肝、脳、網膜などに合併することがある。膵発 生の本邦報告はなく、きわめて稀な症例と思われた。

[結語] 遺伝性毛細血管拡張症に伴う膵頭部動静脈瘦 の一例を経験したので報告した。
I -235髄膜に発生したHemangiopericytoma捇転 移の 1 切除例

名古屋大学第二外科

小山寛一、原田明生、中尾昭公、野浪敏明、金子哲 也、紐野二郎、大島健司、高木 弘

頭蓋内に発生するHemangiopercytomaは主に噵膜に 発生し、きわめて稀な腫痬であり、その捇転移切除 例は文献上報告されていない。今回我々は、本症の 1例を経験したので若干の文献的考察を加え報告す る。症例は55才、男性。主訴は特に無し。1977年 及び1980年にHemangiopericitic meningiomaにて 開頭切除術を受けた。1991年に肝転移を来たし肝右 葉切除術施行。さらに現在までに肝転移、肺転移、 頚椎転移を来たしそれぞれ転移巣の切除を施行して いる。1995年5月CTにて捇体部に腫瘍を認め精査施 行。腫瘍は造影CTで辺縁部が濃染され、腹部血管造 影ではhypervascularで腫瘍濃染像を呈した。ERPで は主苇管の圧排像のみで、血液生化学検查、腫瘍マ ーカーも正常であった。Hemangiopericytomaの䐙転 移と診断し1995年10月捇分節切除術施行。腫場は 弾性硬、直径 $3 \mathrm{~cm}$ でありリンパ節転移、門脈浸潤を 認めなかった。病理組織所見では、核細胞比が高い 紡錘形の細胞が、細い血管脘を囲むように増殖して おり従来の転移巣の組織と同一と診断された。

I -236 膵癌の臨床病理学的検討 一特にリンパ節転移を中心に一

金沢医科大学一般消化器外科

斎藤人志、明石浩一、瀬島照弘、村山茂美、 佐原博之、瀬戸啓太郎、秋山高儀、小坂健夫、 喜多一郎、高島茂樹

[目的］膵癌の膵周囲進展度とリンパ節転移の関連 性について検討した。

[方法] 膵癌切除症例 31 例（根治度A $\mathrm{B}: 14$ 例、根治度 C:17例）を対象とした。

[結果] 治療術式は脺頭切除が22例、膵体尾部切除が 6 例、膵全摘が 3 例で、リンパ節郭清程度別では $\mathrm{D}_{2}$ が 5 例、 $\mathrm{D}_{2}+16 \mathrm{~b}_{2}$ が 26 例（3例は $16 \mathrm{a}_{1}$ も含む）であった。膵周囲進 展度 $(t)$ 別の内訳は $t_{1}$ が2例、 $t_{2}$ が 9 例、 $t_{3}$ が20例であった。 切除症例 31 例のうちn(+)症例は27例 (87.1\%)であった。 肉眼型では浸潤型が組織型では中分化型が高いn(+)陽性 率を示した。t 症例に $\mathrm{n}(+)$ はなかった。 $\mathrm{t}_{2} \mathrm{n}_{1}$ が 5 例 $(55.6 \%) 、 \mathrm{t}_{2} \mathrm{n}_{2}\left(12 \mathrm{p}_{1}, 16 \mathrm{~b}_{1}\right)$ が 2 例 (22. 2\%)、 $\mathrm{t}_{3} \mathrm{n}_{1}$ が 12 例 (60\%), $\mathrm{t}_{3} \mathrm{n}_{2}\left(14 \mathrm{a}_{2}, 16 \mathrm{a}_{2}, 16 \mathrm{~b}_{1}\right)$ が 3 例 (15\%)、 $\mathrm{t}_{3} \mathrm{n}_{3}\left(3,5,16 \mathrm{~b}_{2}\right)$ が5例(25\%)であった。

[結語］脺周囲進展度に伴ったリンパ節転移程度の 進展がみられ、特に浸潤型で $\mathrm{t}_{2}$ 以上の膵癌症例に対して は術中病理診断を用いた $\mathrm{D}_{2}$ 以上の郭清を伴う膵切除が必 要と思われた。 
I-237膵癌切除術症例における術前血清 CA19-9 値及びその術後変動と予後との関連性について 名古屋大学第 2 外科

大島健司, 中尾昭公, 原田明生, 野浪敏明, 金子哲 也, 野本周嗣, 武内有城, 高木弘

1985 年 4 月から 1995 年3月までに当教室で切除術を 行った膵癌 66 例を対象として術前及び術後 2,4 週の血 清CA1 9-9值を測定しその変動と予後の関連について 検討した。また開腹時肝組織のK - ras point mutationについて検索し得た 15 例ではその発現と血 清CA19-9值との関連についても検討した。術前值が $37 \mathrm{U} / \mathrm{m} 1$ 以上の陽性例は陰性例に比し予後不良の傾向 で、特に $2000 \mathrm{U} / \mathrm{m} 1$ 以上の陽性例では2000U $/ \mathrm{ml}$ 未满 の陽性例に比し有意に予後不良であった。また術後2 週で陰性化せずさらに4週值が2週値よりも増大した 症例は特に予後不良であった。再発形式では術前 $3000 \mathrm{U} / \mathrm{m} 1$ 以上の症例で腹膜再発が高率で、2週值が 術前值の $30 \%$ 以下隇少しなかった症例で肝再発が高 率であった。血清CA1 9-9值は術後腫湯残存、再発の マーカーとして有用と思われた。また術前血清CA199值と関係なく肝組織 K-ras point mutationの発現は 高率 $(12$ 例, $80 \%)$ に認められ潜在性肝転移が示唆され た。膵癌切除症例ではこれらに留意して診療する必 要性がある。

\section{I -238 脺癌皮膚転移 5 例の検討と文献的考察 山口大学第 2 外科}

宮原 誠, 濱中裕一郎, 西原謙二, 川端章弘, 上野富雄, 佐藤泰之, 田中昭吉, 山本 明, 岡 正朗, 鈴木 敞 膵癌の皮䖉転移は比較的稀である。脺癌皮䖉転移 自験例 5 例と文献的考察を加えて報告する。自験例 の年齢は43〜76歳、平均 60歳。男女比は 4：1。皮膚 転移部位は、臍3例, 頭皮1例, 左頃部1例であった。 4例は皮虐転移病変が、主腫瘍の診断に先行して出現 しており、その内2例は初発症状であり、2例は初診 時に発見された。他の1例は、膵癌手術1年後に出現 した。原発巣は、頭部癌 2 例、体尾部癌3例であった。 3例は肝、肺転移を伴っていなかった。膵癌皮膚転移 報告17例（1939-1995年）の検討では、そのほとんど が皮膚転移は主腫瘍の診断に先行して出現しており、 臍転移が多く、また体尾部癌由来のものが多かった。 画像診断の発達した現在においては比較的容易に萪 癌の診断が行いうるようになったが、転移性皮膚病 変が初発、初診症状あるいは再発の兆候でありうる ことは稀ながらも重要な特徴であり、また膵癌の根 治手術を考慮する場合、遠隔転移としての肝、肺転 移のみならず、皮膚転移の有無を正確に判定するこ とは、癌の病期の決定においても重要である。

\section{I -239 術後 5 年以上生存した膵癌症例の臨 床病理学的検討}

岐阜市民病院外科

大下裕夫, 田中千凱, 種村廣巳

【はじめに】近年 “小膵癌”の診断が可能になったも のの, いまだ切除不能例も数多く経験される. しかし, 拡 大手術や集学的治療が導入されて, 少数ながら長期生存例 が報告されるようになった，そこで今回は，当科で手術さ れた膵癌の術後 5 年以上生存例の特徴について検討した.

【対象】1980年〜1990年の11年間に当科で切除された膵 癌のうちで, 術後 5 年以上生存した症例は 6 例で, 生存 4 例, 死亡 2 例である.【結果】術後生存期間は, 生存例で は 7 年 2 力月 2 例, 6 年 3 力月 1 例, 5 年 11 力月 1 例, 死 亡例では 5 年 5 カ月 1 例, 5 年 4 カ月 1 例であった. 占居 部位は膵頭部癌 5 例, 膵全体癌 1 例, 肉眼的性状は結節型 5 例, 浸潤型 1 例であった. 組織学的分類は 6 例とも膵管 癌で, 高分化型 2 例, 中分化型 3 例, 低分化型 2 例であっ た. 組織学的所見では $\mathrm{s}_{0} 4$ 例, $\mathrm{s}_{2} 2$ 例; $\mathrm{rp}_{0} 5$ 例, 不明 1 例; $\mathrm{ch}_{0,1}, 4$ 例, $\mathrm{ch}_{2}, 1$ 例, 不明 1 例; $\mathrm{du}_{0} 3$ 例, $\mathrm{du}_{1,3}$ 3 例; $\mathrm{n}_{0} 6$ 例; $\mathrm{t}_{1} 4$ 例, $\mathrm{t}_{3} 2$ 例; stage I 1 例, II 2 例, IV 3 例であった.【まとめ】術後 5 年以上生存した膵癌症例 では $\mathrm{s}_{0}, \mathrm{rp}_{0}, \mathrm{n}_{0}, \mathrm{t}_{1}$ 症例が多かったが, $\mathrm{s}_{2}$ あるいは 囊壁）といった総合的進行度IVの進行例が 3 例みられた。

\section{I - 240 胃切除後の膵癌症例の検討}

\section{琉球大学第 1 外科}

宮里 浩, 島袋誠守, 玉井 修, 白石祐之, 山田 護 松本光之, 草野敏臣, 武藤良弘

〔目的〕胃切除後の膵癌症例に関してその臨床病理学 的特徵を検討した。【対象〕過去10年間に当科にて経 験した膵癌例 40 例中、胃切除後に発生した膵癌例 4 例 とその他の膵癌例 36 例を膵癌取り扱い規約に準じ比較 検討した。【結果〕胃切除後例は平均年齢 $70 \pm 4.4$ 歳、 自覚症状は腹痛 2 例、背部痛を 2 例、体重减少を 1 例 にみたが、黄㾝は認めなかった。胃疾患は胃潰瘍が 1 例、胃癌が 3 例で、全例が幽門側胃切術を施行され、 再建はBi 11 roth 1 法が 3 例、2 法が 1 例であり、胃切 除後の期間は平均 13.5 年であった。腫瘍切除術は $50 \%$ に施行され、50\%は姑息的手術が施行された。75\%が 根治度 Cであった。腫煌肉眼型では、胃切後例では浸 潤型が75\%を占め、一方、対照群では腫瘳型が83.3\% と大部分を占めた。進行度では、 stage IVが75\%を占 め、腹膜転移、肝転移は対照群との間に差は認めなか った。組織型は、全例管状腺癌であった。50\%生存期 間は 4 か月で予後不良であったが、対照群と比較し有 意差はなかった。〔結語〕胃切除後の患者においては、 消化管のみでなく膵癌の発生の可能性も考え経過観察 することが必要であると考えられた。 
I - 241 膵臓の solid and cystic tumor の診断 で手術を施行した肝十二指腸間膜リンパ節結核の 1 例

\section{信州大学第 1 外科}

横山隆秀，宮川眞一，野池輝匡，島田良， 北村宏, 野村和彦, 小林聡, 原田晴久, 川崎誠治 [目的] 術前 solid and cystic tumor と診断し、手術 を施行した肝十二指腸間膜リンバ節結核の 1 例を経験 したので報告する。［症例］24歳の女性で、血液検査 で軽度の胆道系醭素と膵酵素の上昇を認めた。超音波 検査で膵頭部から肝門部にかけて径 $5 \mathrm{~cm}$ の多結節性 の hypoechoic mass を認め、CT、MRI では同部位に、 多囊胞性で一部に充実性成分を持つ腫瘤を認めた。 ERCP で総胆管に壁外性の圧排を、血管造影で門脈本 幹の圧排を認めた。[手術所見］腫瘤は膵荗、肝動脈、 門脈、総胆管から剥離可能であった。 [結果 ] 標本は $7 \times 4 \mathrm{~cm}$ で、乾酪壊死亡 Langhans 型巨細胞を伴う類 上皮肉芽腫を認めた。チールネルセン染色で結核菌を 認めた。[結論]若年女性に認められた脺頭部の cystic な部分を含む充実性腫瘍で solid and cystic tumor と 術前診断された症例であるが、超音波検査では cystic 成分に乏しく、術前画像診断の不一致がみられた。こ のような症例ではリンパ節結核も念頭に置く必要があ ると考えられた。

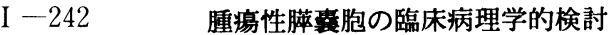

\section{長崎大学第 2 外科}

鬼塚伸也、藤田文彦、西原実、井上啓爾、田島義証、 冨岡 勉、兼松隆之

【目的】近年、画像診断の進歩に伴い荤震胞性病変が 増加しているが、質的診断、治療方針の決定は容易で はない。今回は腫瘍性朠表胞症例の臨床病理学的特徴 と治療方針について検封した。【対象と結果】腫瘍性 脺串胞症例28例(男性14例、女性14例、平均年齡59.5

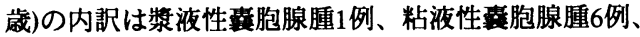
非機能性ラ島腫瘍2例、solid and cystic tumor(SCT)2例、 粘液性糞胞腺癌17例で、術前診断の正診率は粘液性霍 胞腺腫 $42.9 \%$ 、SCT、非機能性亏島腫瘍0\%、粘液性璂 胞腺癌 $41.2 \%$ であった。手術は婁胞切除3例、尾側脞 切除13例、荤頭十二指腸切除9例、切除不能3例であっ た。粘液性䣯胞腺腫の一部に乳頭状増殖、細胞異型を、 粘液性輬胞腺癌で浸潤性増殖、腺腫成分、移行部分を 認め、adenoma-carcinoma sequenceが推測された。予後 は、槳液性 · 粘液性囊胞腺腫、SCT、非機能性ラ島腫 瘍では再発を認めなかった。粘液性婁胞腺癌では9例 が死亡し、8例(6例は3年以上)生存中である。【結語】 腫瘍性荤襄胞の術前確定診断は困難であるが、粘液性 荤糞胞には積極的な外科切除を選択すべきであろう。
I -243 膆胞腺嗹の外科治㙩の問题点

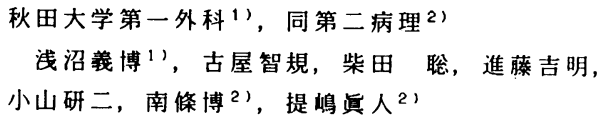

【目的】膵芸胞腺腫 11 例をもとに, 術前の籃別診断と 手術術式の点から問題点を検討した。【対象と方法】 膵莫胞腺腫 11 例の内訳は䏺液性 8 例、粘液性 3 例であり, 腫熄最大径は永液性: $1.3 \sim 8.0 \mathrm{~cm}$, 粘液性: $3.5 \mathrm{~cm} \sim 1$ $2.0 \mathrm{~cm}$ であり, 占拠部位は膵頭部: 体尾部が $4: 7$ であっ た. 術式は膵頭十二指腸切除 $(P D)$ : 膵尾侧切除: 膵分 節切除が $4: 3: 4$ であった。【結果】轞別診断の問題点： 組織診断が墏液性であった 8 例の術前診断は墏液性 4 例, 粘液性 2 例，非機能性 ラ島腫瑝 1 例，転移リンパ節 1 例で あった。一方, 粘液性 3 例の術前診断は粘液性 2 例, 真 性意胞 1 例であった。手術術式における問題点：膵尾側 切除を行った1例で術後遠隔期に耐糖能が悪化した。一 方, BT-PABAによる膵外分泌能が悪化したのは, PD1例（ $92 \% \rightarrow 61 \%)$ ，膵尾側切除1例 $(81 \% \rightarrow 69 \%)$ ，膵分節切除

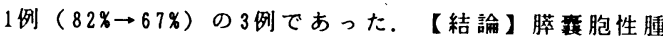
瘍の鑑別診断能をさらに上げる必要がある。また，漿 液性重胞腺腫では，膵切除量を可及的に少なくする膵 分節切除が施行されるべきであると考えられた。

I - 244 当科における荤囊胞性腫瘍の検討 - 特に 衰胞化を伴った荤癌症例について一

鈴鹿中央総合病院外科 ${ }^{11}$, 同病理 ${ }^{21}$

谷川寛自 ${ }^{1)}$,今井俊積, 東俊策, 久留宮隆, 梅田裕之, 林実夫,永井盛太, 村田哲也 ${ }^{2}$

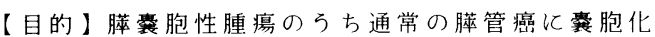
を伴ったと考えられる症例 (以下CC) と粘液産生荤腫瘍 (以下MP) を臨床病理学的飞比較検討した。【方法】MP 4 例とCC4例の画像所見, 手術術式及で病理組織所見に ついて検討した。【結果】MPの4例は腪頭部あるいは尾 部に巨大な霊胞や主腪管全域にわたる囊胞状拡張を認 め, 粘液性荤腫瘍之診断し手術を施行。術式は全摘 1 例, 体尾部切除2例であった（1例非手術）。一方,CC4例は荤 頭部2例，尾部2例でいずれも画像上. 立実性腫瘤と囊胞性 病変を認め,眝留性囊胞を合併した㬸癌と診断し手術を 施行。術式は荤頭十二指腸切除2例, 体尾部切除2例であつ た。組織学的には前者はいずれも非浸潤性乳頭腺癌であ ったのに対して,後者は浸潤傾向の著しい管状腺癌で,隣 接した震胞自身も癌であり，粘液産生性，漿液性のものな ど多彩であった。【結語】腪囊胞性腫瘍の中にはその分 類に苦慮する震胞化を伴った荤癌症例が存在し，その成 因には通常の荤癌が囊胞化したもの, 眝留霊胞への癌浸 潤, 粘液産生苹癌から浸潤癌への進展などが考えられた。 
I - 245 演題取り消し

I - 246 術前粘液性囊胞腺腫と鑑別に苦慮した漿 液性粪胞腺腫の一例

近畿大学第二外科

原之村博, 野村秀明, 藤原郁也, 今野元博,

宮本正章, 藤原英利, 黒田大介, 橋本直樹,

加藤道男, 大柳治正

【症例】76歳、女性。腰痛を主訴に近医内科受診。SAMY及びElastase-Iの高值を指摘され、急性:萊炎の診断 にて当院内科紹介受診。[腹部US] 㬸頭部に $\phi 6.5 \mathrm{~cm}$ の モザイク様low echoic massを認め、門脈を内側に圧排し ていた。 [CT] 萊頭部にsmall calcification が散在する cystic lesion。内部に隔壁様構造を認めた。［MRI］分葉 状のcystic lesion。内部構造は不均一で、隔壁樣構造の存 在が疑われた。 $[\mathrm{ERCP}]$ 荤管は拡張は認めないが軽度 蛇行あり、荤体部の一部までしか造影されなかった。 造影剤が裹胞内へ流入し、充実性占拠性病変を内部に 伴っていた。［血管造影］ hypervascular tumorとして描 出され、強いtumor stainを形成していた。Portal veinは開 存し、encasementは認めなかった。㬸頭部の襄胞性腫瘍 で、血管造影所見から㬸囊胞腺腫を考えたが、MCAと SCAとの明確な鑑別に苦慮した。辐胞内容は黄白色漿液 性の液体であり、割面は間質結合組織からなる蜂巣状 を呈していた。衰胞壁は一層の立方上皮からなり異型 性は軽度であり、SCAと診断した。本症例の画像診断に おける問題点を中心に文献的考察を加え報告する。

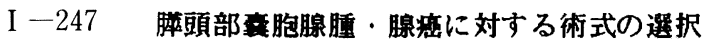
と問題点 虎の門病院消化器外科

渡辺五朗、松田正道、橋本雅司、土肥健彦、堤謙二 木ノ下義宏、梶山美明、宇田川晴司、鶴丸昌彦

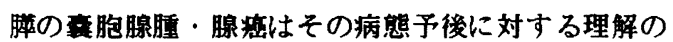
深まりとともに、維小手術が一つの流行となりつつあ る。我々はこれに先だって鉤部切除術として報告した が、局所切除術としての問題点を感じるに至った。今 回は腈頭部に限って、各種術式例を含めて診断学・病 理学的に検討。術式の選択と問題点につき考察した。

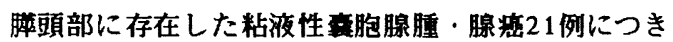
検討した。術式は堙全摘 2、P D 9、鈎部切除 7 、頭 部切除 1 、咅胞切除 2 であった。全摘は初期の多発例 で、鈎部など樎小手術は1989年以降に行った。

局所切除である鈎部切除、真胞切除計 9 例の检討で は、腺渱の 2 例と腺腫の 1 例で組紨学的断端陽性とな った。切除断端すなわち腫席存在分枝基部での進展の 有無の検討として、従来の広䉇囲切除例を含めてその E R P 像につき検討を加えた。基部断端浸泪例では 4 m $\mathrm{m}$ 以上の拡張を示したが、確定診断には他の精査法に よる直接舅察が必要と考えられた。膡液度は縮小手術 の44\%に認められ、脑実筫を剥離するよりも喜胞のみ を可及的に切除するも一法と思われた。

I - 248 Lipid A誘導体による抗腫瘍効果、ヒト膵癌 における単球・マクロファージ活性化因子の検討

神戸大学第 1 外科

高瀬至郎、山本正博、神垣 隆、長谷川恭久、 石田英文、大橋 修、斎藤洋一

[はじめに] 腫瘍局所の単球・マクロファージの活性 化は癌細胞から産生されるサイトカインの発現により 異なることが予想される。今回、Lipid A誘導体（ONO -4007）を用いてヒト脺癌細胞と共培養した単球のTNF 産生を指標に単球・マクロファージの活性化因子を検 討した。［方法］健常人より比重遠心法にて単核球を 採取した。ヒト膵癌細胞株（BxPC-3、MIA-PaCa2、 Panc-1）と単球を非接触下に共培養後、ONO-4007にて 刺激しTNF- $\alpha$ の産生量を測定した。また、膵癌細胞株 の培養上清をGM-CSF、M-CSF中和抗体処理後、その 培養上清で単球を培養しTNF発現を検討した。［結果］ 膵癌細胞株と共培養後の単球のTNF産生量はPanc-1、 MIA-PaCa2、BxPC-3の順に高く、単球単独培養にくら べ有意に高かった。また、M-CSFおよびGM-CSF中和 抗体を用いることによりONO-4007刺激によるTNF産生 量が減少した。 [まとめ]腫瘍細胞から産生される M-CSFやGM-CSFなどが、腫瘍局所の単球・マクロファ ージの活性化に作用している可能性が示唆された。 
I -249浸潤性脺管癌におけるLaminin(LN)および Fibronectin(FN)発現の臨床病理学的意義

島根医科大学第一外科 平原典幸,仁尾義則, 三成善光,佐藤仁俊,上垣賢， 寺本睦,角昭一郎, 田村勝洋

(目的) LN,FNは, 基底膜成分であり, 癌の浸潤・転移 に関与している.今回, 浸潤性膵管癌の原発巣44例, 転移 栄22例および良性疾患22例を対象に,LN,FNの発現を 免疫組織学的に検索し, 病理学的意義を検討した.(結 果)(1)基底膜LNは原発巣 $32 \%$,転移巣 $23 \%$,良性疾患 $50 \%$ に発現した.また,基底膜FNは原発巣 $2 \%$,転移巣 $10 \%$, 良 性疾患 $18 \%$,周囲間質FNは原発巣 $39 \%$,転移巣 $32 \%$, 良 性疾患 $100 \%$ に, 細胞質FNは原発巣 $91 \%$,転移巣 $86 \%$, 良 性疾患86\%に発現した.(2)t因子別基底膜LNの発現率は, $\mathrm{t} 1,20 \% ; \mathrm{t} 2$ 以上,33\%で,細胞質FNの発現性はt $1,80 \%$; $\mathrm{t} 2$ 以 上,92\%,周囲間質ではt $1,20 \%$; 2 以上, $41 \%$ で, 病期の進行 に伴い発現性は上昇した.(3)基底膜LN発現例は有意に 予後不良であった.(4)基底膜 $\mathrm{LN}$, 細胞質および周囲間質 FNの 3 種類の陽性度での検討では, $\mathrm{t} 1$ 症例で2因子以上 陽性例, 20\%; t 2 以上の症例で $47 \%$ であった. 同様に,n(-) 症例で,33\%; $n(+)$ 症例で42\%であり,病期の進行に伴い, 陽性度は上昇した。また,2因子以上陽性例は有意に予 後不良であった.(結語)基底膜成分の総合的解析によ り,より正確な生物学的悪性度の評価が可能である.

I - 250 腆癌における神経栄食因子 (Neurotrophin-3, NT-3)の発現について

金沢大学第二外科 ${ }^{11}$, 浅八川総合病院外科 ${ }^{2)}$ 太田哲生 ${ }^{1}$, 月岡雄治, 二上文夫, 北川裕久, 首原正都，永川宅和，宮崎逸夫，上野桂一2) [目的]粠癌細胞が神経增生作用 (neurogenesis)を有 する神経栄䖭因子を分泌して癌巣周囲の末梢神経に作 用しているか否かを知る目的で, 神経栄食因子の 1 つ でるNT-3に着目して膰癌細胞での発現を换討した。 [方法]10例の新鮮標本 (膵嗝8例, 正常膵 2 例), 6 種類の

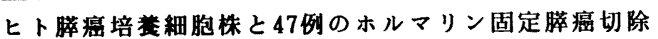
標本を対象にしてNT-3の発現を蛋白レベルとmRNAレデ ルでみた。 [結果]膀癌組樴ではmRNAレベルで8例全例 が正常膀より有意に過剩PCR産物が認められ, 蛋白レベ ルでは47例中 34 例 $(72 \%)$ の膵癌細胞にNT-3免疫反応物質 が確認された。その免度反応物質はとくに癌先進部に 強く発現していた．また膵癌細胞株では6例中5例でNT -3の発現がロRNAおよび胥白レベルで確琵された。

[まとめ]七ト膵癌細胞では, 神経栄飬因子の 1 つであ るNT-3を過剩発現し，そのNT-3は癌周囲組織内（とく に，後腹膜組幽）にみられる末梢神経（膵頭神経叢か ら分布している神経終末) の神経增生 (neurogenesis) に深くかかわっている可能性が示唆された.
I - 251 膵癌の浸潤、転移におけるサイトカイン および脺癌由来因子による遊走能増強効果の影響 大阪市立大学医学部第一外科

櫻井康弘、澤田鉄二、鄭 容錫、仲田文造、平山晃司、 西原承浩、前田 清、曽和融生

[目的］膵癌の浸潤、転移における遊走能との関連 を、サイトカインおよび莢癌細胞由来因子の遊走能に およほす影響を中心に検討を行った。［方法］ヒト 膵癌細胞株SW1990, PANC-1を用い、遊走能の検討は、 Trans well double chamberにて\% of Motilityで評価した。 サイトカイン(TGF- $\beta$, HGF, TNF- $\alpha$, IL-1 $\alpha$, IL-6)を 添加した際の、遊走能および細胞形態におよほす影響 を検討、さらに高転移性SW1990細胞無血清培養上清 (SW-C.M.) 添加時の遊走変化を検討し同因子の精製を 試みた。[結果］SW1990の遊走能はTGF- $\beta$ 添加で 若干増強、PANC-1では、各サイトカイン添加で強い 遊走能増強がみられ、一部線維芽細胞様変化が認めら れた。SW-C.M. 添加にて各々の細胞の遊走能は増強 し、PANC-1においては約3倍の増強とともに形態変 化も確認された。種々の検討より既知のサイトカイン とは異なり、新しい因子である可能性が示唆された。 [結語] 種々のサイトカイン、膵癌細胞より産生さ れる遊走刺激因子が㬸癌の浸潤、転移促進に大きく関 与している可能性が示唆された。

I - 252 膵癌におけるEGF family とその受容体の 発現の臨床病理学的意義

島根医科大学第一外科

上垣 賢, 仁尾義則, 寺本 睦, 佐藤仁俊, 平原典幸, 田村勝洋

【目的】膵癌におけるEGF family とその受容体の発 現と臨床病理学的因子との相関について検討した。

【方法】対象は膵癌原発巣53例及び転移巣26例を用 い, EGF,TGF- $\alpha$, EGFR,c-erbB-2 蛋白の発現につい て, 免疫組織染色を行い, 検索した。【結果】原発巣 での各因子の発現率は,EGF $28.3 \%, \mathrm{TGF}-\alpha 43.4 \%$, EGFR $66.0 \%, c$-erbB-2 蛋白 $40.0 \%$, 転移巣では 各々 $46.1 \%, 46.1 \%, 80.1 \%, 34.6 \%$ あった。各因 子単独では, 原発巣, 転移巣亡も, 各因子及び受容体の 発現に関わりなく,生存率,臨床病理学的因子に有意な 差を認めなかった。一方, 切除例においてのみEGF(+) $\operatorname{EGFR}(+)$ 群の生存率は, EGF(+) EGFR(-) 群に比較し て有意に不良であった。他の組合せでは,特に有意な 差を認めなかった。【結語】今回の検討では䐏癌の 臨床病理学的進行度と各因子単独の発現との間には, 明らかな関連を認めなかった。しかし,今回のように EGF family の発現亡受容体の発現亡を併せて解析す ることで, 脺癌における生物学的悪性度の指標となり うる可能性が示された。 
I - 253 ハムスター腪癌モデルに対する緑茶および 紅茶エキスの抑制効果について

大阪市立十三市民病院外科 ${ }^{11}$, 大阪市立大学第一外科 ${ }^{2)}$

日裏彰人 ${ }^{1)}$, 佐竹克介 ${ }^{21}$

【目的】膵癌に対する緑茶エキス(GTE), 紅茶エキス (BTE)の癌抑制効果を検討するため以下の実験をおこ なった。【方法・結果】実験 $1: B O P$ 誘発ハムスター荤 癌モデルに水道水を与えた対照群(C群), $0.5 \mathrm{mg} / \mathrm{L}$ の GTE,BTEを与えた群(G群,B群)の 24 週後の膵癌発生率 を比較した。実験2:BHP誘発膵癌の皮下継代移植ハム スターに水道水を与えた対照群(C群), $0.5 \mathrm{mg} / \mathrm{L}$ の GTE,BTEを移植3週後から与えた群(G群,B群)の移植 15 週後の腫瘍の大きさ，腋窩リンパ節転移率を比較した.

\begin{tabular}{|c|c|c|c|c|c|}
\hline \multirow[t]{2}{*}{ 実験1： } & & \multicolumn{2}{|c|}{ 発生率(\%) } & \multicolumn{2}{|c|}{ 発生頻度(個) } \\
\hline & & 癌 & 異型過形成 & 癌 & 異型過形成 \\
\hline \multirow{7}{*}{ 実験2： } & C 群 & 53.8 & 92.3 & 1.92 & 4.65 \\
\hline & $\mathrm{G}$ 群 & 44.4 & 77.8 & 0.89 & 1.50 \\
\hline & B群 & 50.0 & 81.3 & 0.88 & 1.38 \\
\hline & & \multicolumn{2}{|c|}{ 腫鈞の大きさ $\left(\mathrm{mm}^{3}\right)$} & \multicolumn{2}{|c|}{ リンパ節転移率(\%) } \\
\hline & C 群 & \multicolumn{2}{|c|}{$1.98 \pm 0.23$} & \multicolumn{2}{|r|}{81.8} \\
\hline & G 群 & \multicolumn{2}{|c|}{$1.18 \pm 0.15$} & \multicolumn{2}{|r|}{66.7} \\
\hline & B群 & \multicolumn{2}{|c|}{$1.07 \pm 0.15$} & \multicolumn{2}{|r|}{62.5} \\
\hline
\end{tabular}

【結論】ニトロソ化合物誘発ハムスター腪癌に対して, 緑茶エキス，紅茶エキスともにantipromotionおよび antiprgoression作用を有することが示唆された.

\section{$\mathrm{I}-254$ 小膆癌の2例}

神戸市立中央市民病院第 1 外科

藤家 悟, 橋本 隆, 柳橋 健, 小西 豊 谷 友彦, 梶原建熙

\{症例\}症例 1：64才女性.近医にてUS 異常所見あり. 精查目的にて当院を受診.USおよびCTにおいて MPD拡張を認めた.US下MPD穿刺造影, ERP同時施行像 にてMPDは頭部で完全閉塞, 拡張した尾側MPDとの間 に交通は無く,閉塞部付近に約 $1 \mathrm{~cm}$ 大の内腔に突出する 腪腫瘤像をみた.Angiographyでは異常所見は無く、膵 液細胞診ではclass2であったが膵癌との鑑別困難であ りD1の荤体尾部切除術を施行. 病理診断は狭窄MPD周 囲の狭い範囲にびまん性に3.0x4.0 mmの大きさに浸潤 するtub2であり、8番リンパ節に転移を認めた。症例 2 : 73才男性. 主訴 体重減少、全身倦意感。USにて膵 体部にhypo echoic noduleをみとめた。CT、MRIにお いては異常像を認めなかった。Angiographyではtumor stainをみとめ同時施行のUS-Angioではhypovascular tumorをみとめた。ERPでは異常所見を認めず、同時 施行の胨液細胞診ではclas s2であった。荤癌の術前診 断にてD2の荤体尾部切除術を施行した。術後病理診断 は $5.0 \times 6.0 \mathrm{~mm}$ の tub2 でありリンパ節転移はみとめなか った。
I -255 勝顽部主膵管並びに下顽枝領域切除を

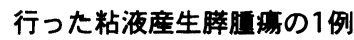

松阪中央総合病院 外科

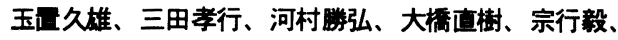
湯浅浩行

【はじめに】粘液産生膵腷娚は低悪性度であるため 十二指腸温存膵頭切除や膡の区域切除など機能温存手 術の対象となっている。しかし病变が表屈拡大性かつ 這続性に広がるため切除籍囲の決定に嚾渋し広籍な切 除を余隻なくされることがある。今回我々は膵頭部に

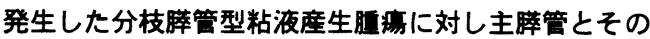
下頭枝領域切除を行った1例を経験したので報告する。

【症例】72才、男性、腹部症状はなかったがal-p とamyl aseの上無がみられたため精査を行うとUSに て膵鉤部に豆胞性病变がみられERP、細胞診から主膵 管下顽枝領域の粘液産生腷湯と診断し手術を施行した。 乳顽部より主膵管を剥磪温存して病変分枝を含めた全 下頭枝を膵実質とともに切除した。術中柬結切片で 腺缰と診断されたが切除側膵管断端粘膜に䐩湯細胞が 認められたため胆管、副膵管を損偒せぬよう頭部主膵 管を切除した。切除主搼管内に胴游の進展はなかった。

【結語】膵頭部の分枝膵管型粘液産生胵漳に対し主 膵管と下頭枝領域の切除を行った。かかる例には膵管 系を考虑にいれた切除算囲を塄択すべきと考えられた。

I -256 粘液産生を認めない䏬管内乳頭腺痖の一例

市立声屋病院外科

池田直樹、奥村賢三、藤井 真、佐谷 稔 症例は80歳女性。平成7年6月急性膵炎の診断で入院 加療し軽快したが、8月に急性腈炎が再燃したため精

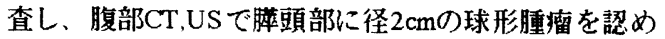
た。腫瘤は主粗管より下方に存在し上端が主膵管に接 しており、ERCPでは主粗管に一部壁不整像を認めた。 血管造影では腫瘤はhypovascularでencasementなどは認 めなかった。内分必学的検索では異常を認めなかった。 以上より膵頭部癌またはnon-functioning islet cell tumor の診断で手術を施行した。腫瘍は厚い被膜に包まれ、 周囲組織より比較的容易に剥離できた。被膜は主膵管 に移行しており主膵管は一部切除を余儀なくされた。 リンパ節転移、被膜外への浸潤を認めず、術中病理診 断で非常に高分化な乳頭腺癌とのことで、主膵管十二 指腸側断端は閉鎖し、尾側粗断端は嵌入式膵胃吻合を 行った。病理組織学的に粘液産生をほとんど認めない 膵管内乳頭腺癌と考えられ、文献的考察と共に報告す る。 


\section{I - 257腫瘍栓にて膵管の拡張と閉塞性黄疸を来 した膵giant cell carcinoma (osteoclastoid type) の 1 例}

$\begin{array}{lll}\text { 系魚川総合病院外科 } & \text { 吉田 徹 } & \text { 鈴木修一郎 } \\ & \text { 新保雅弘 } & \text { 東山考一 }\end{array}$
富山医科薬科大学第 2 外科 坂本 隆

症例は 50 歳女性。心窩部痛を主訴に当科受診。腹部 超音波検査にて膵管の拡張を指摘され、精査進めたと ころ膵頭部に腫瘍を認め、手術目的に入院となった。 入院後、閉塞性黄疸を来たし P T C Dを行った。膵頭 部癌の診断のもと幽門輪温存膵頭十二指腸切除術施行。 膵頭部に直径 $3.0 \times 2.5 \times 2.0 \mathrm{~cm}$ の腫瘍主病巣 が存在し、それに連続して膵管を閉塞させる腫瘍塊を 認め、これが膨大部まで伸び閉塞性黄疸までも引き起 こしたと考えられた。この腫瘍塊は非浸潤性であり、 腫瘍栓の形態をとっていた。病理組織診断の結果、 giant cell carcinoma (osteoclastoid type) であっ た。同腫瘍は稀な疾患であるが、本症例はその組織型 のみならず、腫瘍の進展様式においても特異であり報 告した。

I - 258 胃癌を合併し、肝転移の診断にportal CT が有用であった悪性インスリノーマの 1 切除例 鳥取市立病院外科

木村臣一、山下 裕、湯村正仁、前田宏治、

仁熊健文、河島留一、小谷穣治

インスリノーマは比較的まれで、診断治療上、腫瘍 の局在診断が重要であるが、転移を伴う場合には転移 单の診断も重要となる。我々は肝転移の診断、術式の 決定にportal CTが有用であった悪性インスリノーマ の 1 例を経験したので報告する。症例は68歳、女性、 初発症状は意識消失発作であった。発作時に血糖は低 值を示し、ブドウ糖の静注にて意識は回復し、空腹時 インスリンが高值を示した。エコーにて膵体部に $2.8 \mathrm{~cm}$ 大の腫瘍と肝右苯に腫瘍像を認めた。CT、MRI では脺腫瘍は指摘困難で、肝腫瘍は右葉に限局すると 診断した。しかし、血管造影時に施行したportal CT にて肝腫瘍は右葉だけでなく左葉にも多発していた。 胃癌も発見され、膵体尾部切除、肝切除、胃幽門側切 除を施行した。膵体部に結節型の $3.5 \times 3.0 \mathrm{~cm}$ の腫瘍と 両葉性の多発肝転移を認めた。膵腫瘍と肝腫瘄は組織 学的にislet cell tumorであり、免疫組織染色にてイン スリン、 pancreatic peptide とCh romogranin Aが陽性 で、インスリノーマを診断した。胃癌はtub1の粘膜癌 であった。術後はインスリンも血糖も正常值となった。

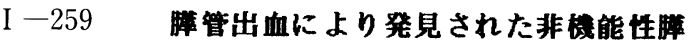

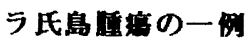

済生会山形済生病院外科1)、山形大学医学部第二病理2)

吾妻正章、瀬尾伸夫、太田圭治、矢作祐一1)、

山川光德、山田和彦2)

腈ラ氏島腫病は、膵腫席全体の約 $1 \sim 3 \%$ と比較的 稀な疾患である。その中でホルモン産生腫㿋は特異的 な臨床症状を呈するが、ホルモン産生の見られない非 機能性腫度では、腫㾂の增大による腹部腫㿔、腹痛、 黄㡺などで発見されることが多い。今回われわれは、 脺管出血という稀な症状により発見された非機能性の 膟ラ氏島腫燷を経験したので報告する。

症例は、49才女性。現病歴は、平成 6 年春頃より動 㥪が出現した。7月の健診にて盆血を指摘され、9月 20日めまいが出現し近医を受診した。精査にて慢性膡 炎、莝管出血の診断にて当科紹介となる。入院時検査 所見では、H b 7.6g/dlと䟺血がみられた。E R C Pに て V a t e r 乳頭部より出血を琶め、膡管内に凝血塊 を認めた。腹部超音波、腹部 C $\mathrm{T}$ 検査にて粗尾部に石 兏化を恝めた。腹部血管撮影では、石死化上部の膆尾

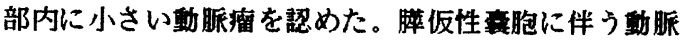
瘤破裂の診断にて11月 4 日膵尾側切除術を施行した。

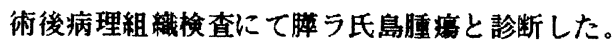

I - 260 術前診断し得た䐙 somatostatinoma の1切除例 一本邦報告16例の検討一

奈良県立三室病院外科

上野正義、金泉年郁、江本宏史、杉森志穂、 小林豊樹、八木正躬

膵原発 somatostatinoma の1例を経験したので、本邦 報告16例を集計し、文献的考察を加えて報告する。

症例は64歳女性。人間ドックで萃腫瘤を指摘され、 精査目的にて当院内科に紹介された。理学所見、血液 生化学検査、腫瘍マーカーに異常を認めず、境界型の 耐糖能障害を認めた。末梢血中ソマトスタチンが50 $\mathrm{pg} / \mathrm{ml}$ （正常值 $1.0 \sim 12 \mathrm{pg} / \mathrm{ml}$ ）と高值を示した。腹部 エコーにて、腪頭部に径約 $3 \mathrm{~cm}$ の内部不均一な低エコ 一腫瘤を認めた。腹部造影 CT、MRI、血管造影にて、 血管増生の著しい腫瘤を認めた。胆石は認めなかった。 以上より腪原発 somatostatinoma と診断し、䐙頭十二 指腸切除を施行した。病理組織標本では悪性像を認め す、免疫染色ではソマトスタチンのみ陽性細胞を認め た。術後6週目の血中ソマトスタチン濃度は $1.0 \mathrm{pg} / \mathrm{ml}$ 以 下に低下し、術後6ヶ月の現在再発兆候を認めていない。

腪原発 somatostatinoma は malignant potential が低 い悪性疾患であるとの報告が多く、厳重な経過観察が 必要であると考えられた。 
I -261 ゼ活性

九州大学第 1 外科

末原伸泰, 水元一博, 志村英生, 冨永洋平, 田中雅夫

[目的］满発癌におけるtelo meraseの意義を検討する ため, 羘癌組織中の telo merase活性の半定量化を試みた．

[対象］1995年 2 月以降，当科および関連施設にお いて手術された膵癌15例を対象とした。また，正常桠 管 6 例を対照群として用いた。

[方法］採取した組織のtelo merase活性をTR AP （telomeric repeat amplification protocol）法により解析 した. 同時に, ヒト膵痹培養細胞株MIA $\mathrm{PaCa}-2$ の活性 を1000個より希釈して測定し，それぞれの組織の活性 に相当する $\mathrm{PaCa}$-2の細胞数をもって半定量化した.

[結果］tel omera se活性の中央値（25\%，75\%）は, 正常膵管 6 例および茦癌15例でそれぞれ，0.13（0.05， 0.72)，34.7（4.98，296）であり, 癌組織において有 意な活性の上昇を認めた $(\mathrm{p}<0.001)$.

[結語] 櫒癌におけるtelomerase活性の半定量化を試 み，癌組織において有意な活性の上昇を認めた。膵発 癌過程において, telomeraseは重要な役割を果たしてい ることが示唆された.

I - 262 ヒト膵癌細胞におけるbafilomycin A1に よる增殖抑制効果についてー-ー特にアポトーシス誘導 による腫演抑制効果---

金沢大学第二外科

荒川 元, 太田 哲生, 二上 文夫, 八木 治雄 長森 正則，北川 裕久，伏田 幸夫，葍原 正: 都 永川 宅和, 宮崎 逸夫

[目的］bafilomycinA1を用いて癌組織内でのVATPaseの作用を抑えることにより増殖を抑制するこ とが可能か，またその增殖抑制とアポトーシス誘導の 関連について膵癌培盖細胞株を用いて実験的に研究し た。[方法]m-RNAレベルでV-ATPase の過剩発現を 浔めたCapan-1 細胞を使用した。in vivoの実験では nude mouseにCapan- 1 細胞を $1 \times 10^{6}$ 個皮下移植 し增殖能を比較検封した。in vitroの奏験ではMTT assay法で効果判定をした。アポトーシス誘導の検出 にはDNAの電気泳動とflow cytometryを施行した。 [結果]in vivo奏験結果においてbafilomycinA 1 处踶 群は腫瘍增殖が抑制され，アポトーシスを認めた。ま たin vitroの実験においてはDNA fragmentation analysisにてアポトーシスが検出された。[まとめ] Capan-1細胞は, bafilomycinA1でアポトーシスが 誘導され增殖が抑制されることが示唆された。
I - 263 䐙胆道癌における門脈 $3 \mathrm{D}$ 表示の有用性

東京女子医科大学附属第一获院外科 ${ }^{* 1}$ 放射線科 ${ }^{* *}$

洼田公一、熊澤健一、細川俊彦、大不俊典、

㙁澤俊一、押部信之、t:慰 玲、小川健治、

芳賀駿介、梶原哲郎 ${ }^{*)}$ 、岩井恵美子 ${ }^{* *}$

【目的】膵胆道癌に門脈 $3 \mathrm{D}$ 表示（3D）を行い、 門脈浸潤度診断について経動脈性門脈造影 (PG) と 比較しその有用性を検討した。【対象と方法】3 Dを 作成した膵胆道癌24例を対象とした。切除は11例で あった。スパイラルCT門脈造影を施行し $3 \mathrm{D}$ 作成 した。門脈の変化は4段階に分類して評洒した。【成 績】PGでの完全狭寉例や側副血行路の多くは $3 \mathrm{D} て ゙$ は描出されず、3 Dではしきい值以下の吸収値の血管

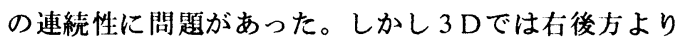
の観祭でPGにない新たな压排像を3例に確認でき、逆 に $3 \mathrm{D}$ ではPGで変化を示す不均一な層流でも明眿な 画像が得られた。切除 11 例の $3 \mathrm{D} 、 \mathrm{PG}$ と肉眼所見の 対比では91\%、55\%が一致した。PGでは偽陰性が多 く門脈浸潤を過小秤価しやすく、3 Dのほうがより正 確で門脈浸润度診断に有用であった。【結論】 $3 \mathrm{D}$ 門脈の変化を最適な方向から観祭でき、小病変を描出 できた。また 3 Dは血管内面の微妙な変化む描出でき

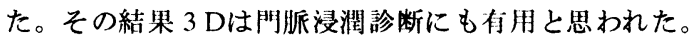

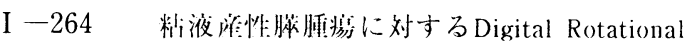
Pancreatography(DRP)の们川性の検洲

\section{下菒大受第 2 外科}

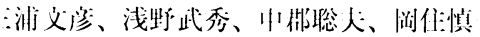

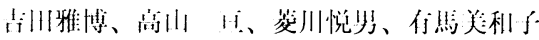

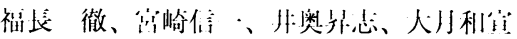

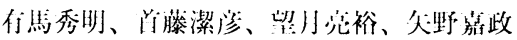

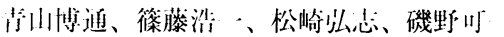

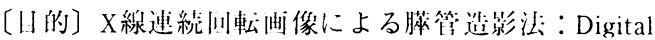

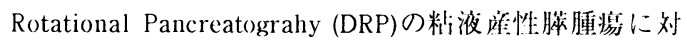
する们归性について検融した。

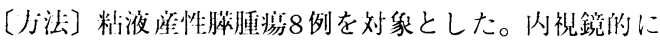

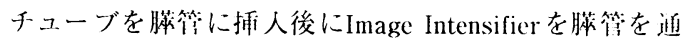

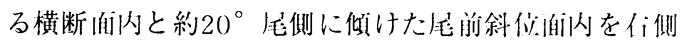

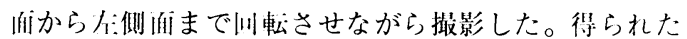
速続動画像より齐苏管分枝、将変蔀を问起して、检湖 を加えた。

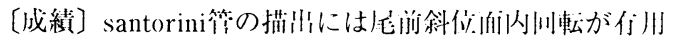

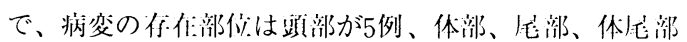

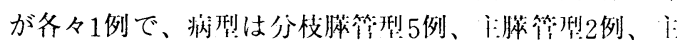

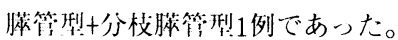

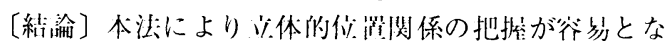

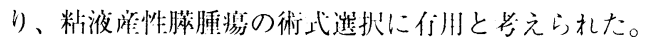




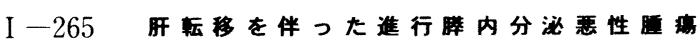
に対する集学的治泰の有用性

\section{- - - 3 年以上長期生存例の检时 - .}

国立津病院外科

石田亘宏、木田英也、三田正明、日高直昭

【目的】当科における肝転移を伴った進行腲内分泌 悪性腫㿋 3 年以上長期生存例 3 例につき集学的治療の

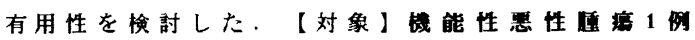
(Zo11inger-E11ison 症候群)：4 年生存中. 非機

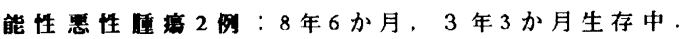

【結果】 3 症例はいず机も肝転移のみでなく、リンパ 節転移も喼められ，また 2 例に腹膜播種，1例に卵巣 転移も慧められたが，原発巣の積極的な切除を施行。 UFTを中心とした全身化学癔法に加え，肝転移巣に 对しては趿注化学療法を施行し.sponge1TAEを施 行した 2 例に 2 年および 3 年のCRが得られている。 【まとめ】(1) 睡内分泌悪性腫㿋肝転移巣に対して はspongel TAEが最も有用で, CRも期待できる。

(2)腹膜播種症例でも長期生存が得ら机ており，全 身化学療法の有用性も示唆された。（3）原発巣に对 する化学療法の効果は不十分であり，原発巣に対して は肝転移、腹膜播璉を認めてもリンバ飭郭清を含めた 積極的な外科切除が望ましい.

\section{I -266䐙瘄に对する門原合併切除に閶豚一時バ イパスは必要か}

\section{山口大学第 1 外科}

品川秀敬, 守田信義, 小林咗子, 井口智浩, 岡村啓二 高橋 剛, 榎 忠彦, 野島真治, 江里健輔

【目的】門脈一時バイパスの必要性及び適応症例を 知ることを目的とした。「対象と方法」䐙頭部癌切除 例のうち門脈合併切除をした15例を対象とした。15例 のうち単純遮断群は10例、バイパス群は5例で門脈脚 静脈バイパス 3例、門脈大腿静脈バイパス 1 例、門脈 脾静脈バイパス 1例であった。【結果】単純遮断群10

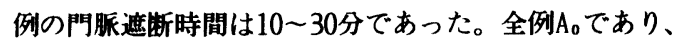
$\mathrm{Rp}_{0}$ 2例、 $\mathrm{Rp}_{1}$ 4例、 $\mathrm{Rp}_{2}$ 4例であった。門脈遮断による 合併应はなかった。バイパス群 5例のバイパス時間は は40〜140分であった。Ao 1例、 $A_{1}$ 1例、 $A_{2}$ 1例、 $A_{3}$ 2例、 $\mathrm{Rp}_{1}$ 1例、 $\mathrm{Rp}_{2}$ 3例、 $\mathrm{Rp}_{3}$ 1例であった。合併症は 1例(肝不全)で血管造影上肝動脈は正常であり、門脈大 腿静脈バイパスを用いた。郭清時肝動脈を損賃し、肝 動腺を遮断したことが原因と考えられた。【結語】(1) 動㟲浸閏及び後方浸閏が高度な店例に対しては門脈一 時バイパスが必要であった。(2)動脈浸潤例では肝動脈 血行を一時的に途絶せさるを得ないことが生じるので、 門脈獜静腺バイパスを用いるべきである。
I - 267荤頭部癌に対する幽門輪温存膵頭十二指腸 切除術 (PpPD) の適応と補助療法の検討

\section{栃木県立がんセンター外科}

菱沼正一, 尾形佳郎, 松井淳一, 尾沢 嚴

【目的】荤頭部癌に対するPpPDの妥当性と補助療法 の成績を, PS, 再発形式, 予後の面から検討した。【対 象・方法】PpPD今永法を行った荤頭部癌20例を対象と した。PpPDの適応は, 胃十二指腸球部に直接浸潤がな く, (6)(5)リンパ節に転移を認めない症例である。術中 士術後照射を12例に行い，1994年 9 月から術中照射十全 肝照射 $(19.8 \mathrm{~Gy}$ )を 5 例に行った。【成績】術後照射 は予定10例中 9 例, 全肝照射は5例全例に完遂しえた。 退院後Follow- up可能15例のPSは, $0: 8$ 例, $1: 4$ 例, $2: 2$ 例, $3: 1$ 例と良好な症例が多かった。Median survival は17カ月で, 切除標本上(6)に転移を認めた 2 例 は38，21カ月生存した。全肝照射 5 例のうち 1 例が術 後 3 力月に消化管出血で, 1 例が16力月に心不全で死 亡したが, 後者は剖検で肺転移のほかに再発はなく, 照 射の肝への影響もみられなかった。残りの3例は術後 $2 \sim 9$ 力月の現在再発を認めていない。剖検 7 例では 後腹膜局所再発を 4 例に認めたが, 幽門周囲に再発が みられた症例はなく, 胃周囲リンパ節への転移を来た した 2 例は, ともに後腹膜局所再発を認めた。

I - 268 膵頭部領域癌の外科治療の問題点 一進展・再発様式よりみた術式の選択-

金沢大学第 2 外科 ${ }^{1)}$ 浅野川総合病院外科 ${ }^{2)}$ 荁原正都1、永川宅和、荒川元、八木治雄、 北川裕久、太田哲生、宮崎逸夫、上野桂一2)

【目的】膵頭部領域癌の根治性を損なわない術式につい て検討する。【対象と方法】膵頭部領域癌 139例 [膵頭部 $(\mathrm{Ph})$ 癌 70 例、下部胆管 $(B i)$ 癌 33 例、乳頭部 $(A)$ 癌 36 例]の 進展・再発様式を検索し、外科治療の問題点について検 討した。【結果】リンパ節転移はPh癌の $79 \% 、 B i$ 癌の70\%、

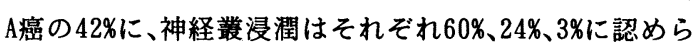
れた。神経叢浸潤部位はPh癌ではPL.ph II が、Bi癌ではPL. ph I が多かった。No.14リンパ節転移率はそれぞれ34\%、 $32 \% 、 16 \% 、$ No. 16 転移率は $19 \% 、 6 \% 、 0 \%$ 、胃周囲リンパ節転

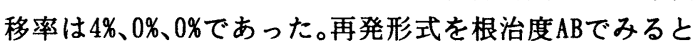
$\mathrm{Ph}$ 癌では、肝転移が73\%、リンパ節、後腹膜再発が $88 \%$ にみ られた。Bi癌では治癒再発6例では全例に後腹膜再発が みられ、膵臟浸潤の強いものが多かった。【まとめ】膵 頭部癌では神経叢完全切除とNo. 14、No.16リンパ節郭清 を、膵䐟浸潤が疑われる下部胆管癌はNo.16を含めたNo. 14 リンパ節郭清とPL.ph I を中心とした郭清を、乳頭部 癌では非露出腫瘤型の一部を除きNo. 14 リンパ節郭清を 行うことが根治性向上に重要であると考えられた。 
I -269 膵頚部領域癌に対する全胃幽門輪温存脺頭 十二指腸切除術の適応とQOLについて

大阪医科大学 一般 - 消化器外科

原 均, 岡島邦雄, 磯崎博司, 森田真照, 石橋孝嗣

【目的】粸頭部領域癌に対し, 全胃幽門輪温存膆頭十二指 腸切除術(PpPD)の適応と術後 1 年目のQOLにつき報告する。 【対象と方法】教室で経験したPD症例で ${ }_{2}$ 以上のリンパ節 郭清を行い, 術後病理組織検查が十分にされた勝頭部領域 癌62例(䅈頭部癌 24 例, 釈頭部癌23例, 下部胆管癌 15 例) を対 象とし, 旁胃壁リンパ節転移を検索した。施行術式は，胃切除 を伴う標準PD57例, PpPD5例であった。また, PpPDの術後状態 を標準PDと比較検討した。結果】対象例中十二指腸第1部 および胃への癌浸潤はなかった。旁胃壁リンパ節転移は4例 (脺頭部癌3例, 下部胆管癌 1 例)であった。脺頭部癌3例の転移 部位は, No.6(8.3\%), No.3(4.2\%), No.4d(4.2\%)ですべて浸潤型,十 二指腸第2部浸潤陽性で, 下部胆管癌1例の転移部位はN 0.5 (6. 7\%)で，結節浸閵型，脺浸潤例であった。術後 1 年目のperform ans statusはPPPDがGrade0 60\%, Grade1 40\%に対し, 標準PD がGrade0 50\%. Grade1 37.5\%, Grade2 12.5\%であった。術前 值の体重に回復する確率は(PpPD60\%，標準PD25\%)であった。 【結論】膆頭領域癌に対するPpPDの適応は十二指腸浸閏の ない䐐頭部癌，乳頭部癌全例, 脒浸閏のない下部胆管癌と 考えられ, 術後のQOLはPpPDが標準PDより良好であった。

I -270 脞頭部領域癌をめぐる外科治療の問題点

\section{国立仙台病院外科}

柿崎健二、山内英生、山田康雄、菊地安徳

（目的）膵頭部領域癌における問題点を治療成績、各種 予後規定因子などの検討から考察する。

乳頭部癌：5年生存率はStageI $88 \%$, ,I $153 \%$, III13\%。この他 (1)腺腫様構造物(NAC)(2)腫留型(3)術前CA19-9值(4)組織 内CA19-9分布で予後に有意差あり。(1)-(4)をみたす症例 では1群リンパ節郭清PD,PPPDの適応と考える。

胆管癌：中下部胆管癌切除例の 5 年生存率Stage $175 \%$, II64\%,III30\%。膵浸潤の有無、MIB-1陽性率、核DNA量 と予後の間に有意な相関を認めた。

蓌癌：中間生存期間は同時性肝転移例2力月、異時性例 10 力月、肝転移のない例で 18 力 $(\mathrm{p}<0.01)$ 。原発巣核 DNA量、癌組織内線維化率は肝転移の有無で有意差あり、 生存期間との間にも有意の相関を認めた。

(まとめ) 1)乳頭部癌では腺腫様構造物の有無、肉眼型 などにより縮小手術(R1 郭清PDorPPPD)選択がしうる。2) 中下部胆管癌では脺浸潤の他MIB-1,核DNA量が予後判定 因子となる。3)膵癌では、癌線維化率、核DNA量が肝転 移予知因子となり得、肝転移の予測される症例では動注 療法などの再考が必要と考える。

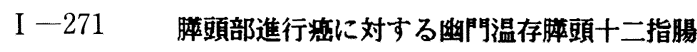
切除, 術中照射併用の試み

大阪大学第二外科

大里浩樹, 左近堅人, 青木太郎, 㭘垣直純, 梅下浩司, 堂 野恵三, 後藤渵一, 門田守人

[目的] 進行膵頭部悪性腫䌿切除例におけるリンバ節の転 移状況を检討し進行膵頭部癌に対するPPPDの妥当性を検討 する. [対象およひ秙果] 1982年から1994年までに当科 における羘頭部癌切除例25例におけるリンバ節の転移率は、 13番 $24 \%, 14$ 番 $20 \%, 12$ 番 $12 \%$, 15 番 $12 \%, 11$ 番 $8 \%, 16$ 番 $8 \%$ ，5番4\%であったが、5番の転移1例 $4 \%$ のみであった. さらに捇癌症例25例中リンバ節転移陽性例10例における転 移リンパ飾数と転移部位を見ると2個までの転移はつ例であ り，1例 5 番のみ 1 個の転移を認めた症例を除いた6例では 12，13，14番のみにリンバ飾転移を慧め，これらのリンパ 飾の切除はPPPDにより十分切除可能と考えられた. しかし， 4個以上のリンバ穊転移を琶めた3例では上記のリンバ節以 外に、11，15，16番への転移を慧め、高度のリンバ行性進 展が伺われた.PpPD, 術中照射療法の併用を行った5例に おける生存, 再発においてPD, 術中照射療法の併用例と有

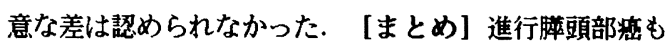
PpPDの適応となりうると考えられた.

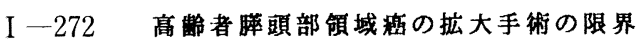
久留米大学第 2 外科

木下言文, 宗宏伸, 柴田順二, 今山裕康, 中山和道 (目的)高歯者手術では術後のQOL が十分に得られる術 式が重要であり，拡大手術が何歳までが妥当かを梌討

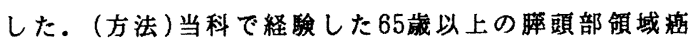
に対するPD症例は103例で, 65〜69嵅:A群 (34例), 70〜7 4 歳: B群 (48例), 75 歳以上: $\mathrm{C}$ 群 (21例)の 3 群に分けて検 討した。(成績)リンn・節郭清程度はA, B 群では $\mathrm{D}_{2}$ 郭清が最 も多く, $\mathrm{D}_{3}$ 郭清は $\mathrm{A}, \mathrm{B}$ 群間では差はなかった.C群では $\mathrm{D}_{1}$ 郭清が最も多く, $\mathrm{D}_{3}$ 郭清はなかつた。門脈合併切除術は C群に最も多かつたが,門脈合併切除に起因する合併症 はなかつた、術後合併症は3群間に有意差はなかつた。 入院死亡例はB群に多く,C群にはなかつた。入院死亡例 のリンn`節郭清程度は $\mathrm{D}_{3}$ 郭清に最も多かつた.5生率は乳

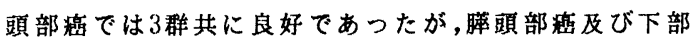
胆管艋では全群共に不良であった。C群での3年以上の 生存例は 6 例で,最長は8年7カ月であり,全例Q0Lは良好 であった。(結論)高齡者ではリンn節郭清は70歳以下で は積極的に拡大郭清を行う必要があるが, 70〜 74歳で は準拡大郭清とし,75歳以上では機能温存などのQOLを 考感した術式と郭清を選択すべきである．血管合併切 除に関しては門脈のみでは75歲以上でも危険性はない が，動脈との同時切除は70歳以下で行うべきである. 


\section{I - 273 腫瘤形成性慢性膵炎症例の検討}

群馬大学第二外科, 同第一内科 ${ }^{11}$

中曾根 豊, 大和田進, 小川哲史, 中村正治, 泉 勝 竹吉泉, 佐藤啓宏, 鴨下憲和, 中神克尚, 小林純哉, 斉藤燈, 森下靖雄, 今 陽一 ${ }^{1}$ [目的] 腫瘤形成性慢 性膵炎は, 臨床的に膵癌との鑑別が困難で治療法も確 立されていない。今回, 腫瘤形成性慢性膵炎の診断, 手術適応, 手術術式の選択について検討した 。[対象 •方法１１990年から1995 年まで当科で手術を 行った腫瘤形成性慢性膵炎症例 7 例 (Child 変法 PD ; 2 例, 今永法 PD；2 例, PPPD；3 例）について, 膵癌との鑑別診断と, 手術術式別に栄養状態, 而糖能, PFD 值の変化を術前と術後で比較検討した。[結果] 診断は, 豊胞や膵石形成が特徽的であった。腫瘤の圧 排による膵管や胆管の狭窄, 拡張像, 門脈の狭窄像を 全例に認め, 膵癌との鑑別は困難であった。術前膵液 細胞診を行った 5 例は全例が陰性であった . 術後に著 明な全身状態の悪化を認めた症例はなく, 特にPPPD 症例では体重, 而糖能, PFD 值の検討から他の術式と 比べ優れていた。

[まとめ]腫瘤形成慢性膵炎と膵癌との鑑別には多角 的画像診断, 穿刺吸引細胞診が必要である. 手術術 式は、術後吸収能の保たれるPPPDが優れていた。

\section{I -274脺頭部領域癌と鑑別が困難であった慢性} 膵炎症例の検討

\section{埼玉医科大学第一外科}

門倉正樹、長島直樹、小山 勇、篠塚 望、松本 隆、田口泰、大畑昌彦、安西春幸、山崎達雄、 尾本良三

慢性脺炎の胆管狭窄で悪性腫瘍と同様の画像所見 を示し,腫瘍マーカーの上昇があるものはその鑑別が 困難である。今回,膵頭部領域癌疑いで開腹し, 術中・ 術後の病理診断で慢性脺炎と確定した症例を術前診 断を中心に検討したので報告する。対象は1988年〜 1995年の膆頭部腫瘤開腹症例57例中,術中・後の病理 診断で慢性膵炎と診断された4例で,膵頭部領域癌53例 と比較した。肝・胆道系酵素(GOT,GPT,ALP, GTP,LAP),血中アミラーゼ,DUPAN-2は両群間で差は ないが,CA19-9は慢性膵炎 $156.9 \mathrm{U} / \mathrm{ml}$,猝頭部領域癌 $531.0 \mathrm{U} / \mathrm{ml} 、 \mathrm{CEA} 2.7 \mathrm{ng} / \mathrm{ml}, 5.1 \mathrm{ng} / \mathrm{ml}, \mathrm{SPAN}-1$ は $77.33 \mathrm{U} / \mathrm{ml}, 180.4 \mathrm{U} / \mathrm{ml}, \mathrm{PFD}$ 試験は $57.0 \%, 74.7 \%$ と慢性脺 炎が低い傾向を示した。術前に癌と診断された症例 はPDの適応となるが,診断不能症例はPFD試験,CA199,CEA,SPAN-1 が指標となる可能性が示唆された。慢 性膵炎4例中2例は術中生検でも鑑別がつかず,PDを施 行した。安全性が向上した現在, 術中に鑑別不能な症 例もPDの適応になりうると思われる。
I - 275 慢性膆炎に対する手術成績と術式の検討 松阪市民病院外科

高橋宏明、早川弘楎、田中穛、岡村一則、

小坂 篤、水本龍二

最近 8 年間に当科で経験した慢性膵炎手術例 10 例を対 象とし、術前の合併病变や術式、並びに手術成績につき 検討した。【成績】年齢は37-75藏、男女比は7:3 男性 に多く、成因では7ルコールが8例、特発性、膵胆管合流異常が 各1例であった。膵病変としては膵管拡張 8 例、腫瘤形成 5 例また糖尿病が 4 例であった。合併病変としては胆管狭 窄 6 例、脾静脈閉塞 2 例があった。施行術式は膵管減圧術 2 例、膵切除術 8 例 (PpPD 6 例、十二指腸温存膵頭切除術 1 例、 膵体尾部切除兼Frey手術1例)であった。術後の疼痛は膆 切除 8 例中 6 例に改善を認めたが、禁酒が守られていない 2例で疼痛が持続していた。また膵管減圧術の1例は疼痛 が再燃し、術後十二指腸の狭窄む認められた。術後の膵 内外分泌機能の变化をみるとPFD試験では明かな改善例 はなかったが、75g-0GTTでは術後悪化例はなく、膵切除 の4例に糖尿病から境界型への改善が認められた。一方、 術後半年以上経過例の体重の変化は、PpPDの6例で術前 値の98-116\%と良好に保たれていた。【結語】慢性膵炎 に対する手術成樍は膵管減圧術では必ずしす良好とは 言えず、特に膵頭部に病変が認められる症例では積極的 に機能温存を考虑した膵切除を行うべきと考えられた。

$\mathrm{I}-276$ 粹炎にともなう周辺動脈の動脈瘤 3 例の検討

東葛病院外科、同臨床病理科 ${ }^{11}$ 、代々 木病院外科 ${ }^{21}$ 、 湍砂一光、大野義一朗、継篤、下正宗 ${ }^{1}$ '、中田友也 ${ }^{2}$ 粠炎に伴う周边動脈の動脈凅は破裂すれは致命的な 疾患である。今回 3 症例を経験したので報告する。

【症例】（１）49歳男性。アルコール性膵炎（２）54 歳男性。外偒性膵炎（３）４6歳女性。慢性膵炎

【症状】3例とも腹痛を訴えていた。また吐血 2 例、 腹腔内出血 1 例であり、このうち 2 例では出血による ショックを呈していた。

【検査】3例とも腹部血管造影にて動脈留を確定した。 部位は脾動脈 2 例、左胃大網動脈 1 例であった。3 例 とも動脈瘤からの造影剤の漏出が確認された。C T 検 査では脾動脈瘤の 2 例では滕衰胞内に濃染される動脈 瘤を認めた。左胃大網動脈溜の例では左横隔膜下に血 腫を認めたか、、動脈瘤自体は同定されなかった。

【治療および予後】2例では腹部血管造影時にスポン ゼルにて動脈瘤を塞栓、止血し、ショックなと全身状 態を改善した後手術を施行し救命し得たが、1例は塞 栓術を行わず、手術を行う前日に吐血し誤蔡窒息にて 死亡した。 
I -277膵石を合併した先天性胆道拡張症に対する 手術々式の検討

$$
\text { 近畿大学第二外科 }
$$

野村秀明, 安田健司, 藤原郁也, 西川正康, 今野元博, 宮本正章, 原之村博, 藤原英利, 黒田大介, 橋本直樹, 加藤道男, 大柳治正 【目的】㬸石を合併した先天性胆道拡張症に対し、拡張 胆管切除十荤頭部芯抜き(Frey 術式)を施行した 2症例につ いて検討した。【対象】先天性胆道拡張症21例 (すべて 㬸管胆道合流異常を合併)のうち、2例 (10\%) に㬸石を認 めた。【症例 1】49歳、女性。腹背部痛有。術前、PFD 90\%、OGTTはDM型。総胆管の襄腫状拡張と、脺管の拡 張および膵石を認めた。術式は、拡張胆管を切除、荤管 切開、荤頭部 coring out の後、1本の挙上空腸を用いて肝 門部胆管空腸吻合、及び荤頭部、荤管空腸吻合術( Roux Y)を行った。【症例 2】40歳、男性。慢性膵炎の急性発 作有。術前、PFD 51\%, OGTT 軽度DM型。総肝管から、 膵内胆管に至る裹腫状拡張と、膵頭部主、副膵管の拡張、 荤石を認めた。拡張胆管の切除、荤頭部 coring out を行う が、脺石は膵頭部に限局していたため、体尾部荤管切開 は行わず。挙上空腸を用いて肝門部胆管空腸吻合、及び 㬸頭部空腸吻合術 $(\rho$ 型 Roux - Y )を行った。【まとめ】 慢性膵炎、膵石を合併した先天性胆道拡張症では、拡張 胆管切除に、Frey 術式を応用した荤管空腸吻合を付加し た本術式は有効である。

I - 278 腹腔鏡下胆裹摘出術後に多量の腹水眝留 を認めた放射線照射後の一症例

\section{大島東部病院外科}

吉野茂文, 重本和弘

今回我々は，子宮癌に対して11年前に放射線照射を 受けた症例に，気腹法による腹腔鏡下胆囊摘出術を施 行し, 術後に多量の腹水貯留を認めたので報告する。

[症例］65歳，女性。 [現病歴］化膿性仙腸関節炎に て当院入院中に右季肋部痛, 湢吐が出現し, 腹部 C T, 超音波検查にて胆石症と診断し, 仙腸関節炎が十分治 癒した後, 気腹法による腹腔鏡下胆囊摘出術を施行し た。［手術所見］胆鞟の炎症所見はほとんど認めず胆 囊剥離は容易であった。肝歲には異常所見は認めなか った。摘出標本では 100個以上の胆囊結石（ビ系石） を認めた。［術後経過］第 7 病日に腹水貯留が認めら れ腹腔穿刺を施行し淡黄色透明な腹水を $2200 \mathrm{ml}$ 吸引し た。第 8 病日には腹水を $9000 \mathrm{ml}$ 吸引, 以後第 $9-14$ 病 日の間, $900-2500 \mathrm{ml}$ の腹水が吸引されたが, 第15病 日の $200 \mathrm{ml}$ 最後に腹水の貯留はみられなかった。

[考察] 放射線照射により障害された腹膜に気腹とい う刺激を与えたために腹水が貯留したのではないかと 推察され，放射線照射後の腹腔鏡下手術では吊り上げ 式を選択すべきではないかと思われる。
I - 279 腹腔鏡下胆霟摘出術後に起こした乳頭部 狭窄の 1 例

岡山大学第二外科

沢田 茂樹、平井隆二、松本 英男、曽我浩之 清水 信義

乳頭部狭窄は、反復する腹痛、膵炎、胆管の拡張及 び胆汁の排泄障害などを示す症候群で、胆石、胆囊炎 や ERCP、胆摘操作などによる炎症が乳頭部に波及す ることが狭窄の原因の一つであると考えられている。 今回我々は、以前に腹腔鏡下胆囊摘出術を受けそれが 誘因と考えられる乳頭部狭窄例を経験した。

症例は 63 歳女性、平成 6 年 8 月に他院で慢性胆囊 炎の診断で腹腔鏡下胆囊摘出術を受けた。術前の ERCP では乳頭部狭窄を認めなかった。平成 7 年 5 月 より繰り返す激しい上腹部痛女り当科紹介。 ERCP で 総胆管の拡張、末端部の狭窄、膵液の胆管内人の逆流 を認めた。内視鏡では、乳頭部に $12 \times 15 \mathrm{~mm}$ 大の半 球状の隆起あり、超音波内視鏡でこれは拡張した総胆 管と判明した。治療は経十二指腸的乳頭形成術を行っ た。藤田らの報告によると、ERCP を行った 1264 例 中 11 例に乳頭部狭窄を認め、この 11 例中 3 例は胆摘 後であった。本症例のように、腹腔鏡下胆䡛摘出術後 でも乳頭部狭窄が起こりうると考えられた。

I - 280 胆豆癌術後に発生した仮性肝動脈癌の 1 治 験例

広岛大学第2外科

丸林誠二, 浅原利正, 藤森正彦, 池田 聡, 福田康彦, 土肥雪彦.

胆䧼癌術後に発生し，動脈塞栓術を施行，根治できた 1 例を経験したので報告する:（症例）患者は62才，男性 で主訴は全身倦急感および腹痛. 平成7年 7 月腹痛生じ近 くの総合病院にて, 胆到症と診断され, 手術のために当 科へ紹介された. 同年10月, 滕頭十二指腸切除ならびに 肝中央 2 区域切除を施行した。術後経過では, 術後 6 日 目より, 発熱 $\left(39^{\circ} \mathrm{C}\right)$,胆道系醇素の上界およびWinslow 孔のドレーンより胆汁の流出を認めた. 術後19日目に突 然 $39^{\circ} \mathrm{C}$ 代の発熱および少目の出血を認めた. 姬急CT検查 を施行したところ仮性肝動脈溜を認め，祭急血管造影を

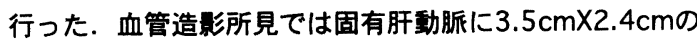
仮性動脈瘦を認めた．そこで，仮性動脈缯に金属コイル による塞栓術を施行した. 以後経過は良好で 2 カ月後に 退院した. (考察) 本症例では, リンパ節郭清などの動 脈壁への損伤および胆管空晹吻合部の梿合不全に起因す る局所感染が誘因となって, 仮性動脈瘤が形成されたも のと推測された. また, 患者の全身状衤の不良例では, 肝動脈塞栓術を第一選択とすべきと考えられた. 


\section{I -281 Alonso-Le j III 型先天性総胆管拡張症の一例}

第一病院外科 ${ }^{1)}$, 内科 ${ }^{2)}$, 東京医科歯科大学第二外科 ${ }^{3)}$ 小田 行一郎 ${ }^{1)}$, 中野 好 ${ }^{2)}$, 北鄉邦昭, 岩間 毅夫, 三島 好雄 ${ }^{3)}$

【症例】43歳男性。平成6年12月より上腹部痛出現。近 医にて，保存的に経過観察されていた。その後も，3回 にわたり同様の症状を認めた。平成7年8月, 上腹部痛, 黄疸, 発熱を認めたため当院に緊急入院となった。入 院時検査所見にて, ビリルビン, GOT, GPT, アミラーゼの上昇 を認めた。腫湯マーカー等は正常筑囲内であった。ERCP施 行時に, 十二指腸乳頭に異常を認めなかったが, 総胆 管への造影剤の注入に伴い, 乳頭部が半球形に腫大を きたした。Alonso-LejIII型のCholedchoceleと考えられ た。【手術・病理所見】胆責摘除術十胆管瘤切除術を 施行した。総胆管内胆汁アミラーゼ值は4520iu/1であった。 組織学的に, 胆言及び累腫壁には悪性所見を認めなか つた。2PODに, 術後出血のため再開腹止血術を施行し たが, その後の経過は順調であった。現在, 外来にて follow up中である。【考察】先天性総胆管拡張症は, Alonso-Lej分類でいう I 型の頻度が高く, III型は比較 的稀である。癌化も稀と考えられているが, 報告例も あるため可及的に，外科的治療を選択するべきである ものと考えられる。

I - 282 総胆管尧腫, 腹側蕠切除術を行っ た苇管胆道合流異常の 1 例

東京医科歯科大学第二外科、慈生会等潤病院外科・

市川 度、長内孝之:、東郷実孝*、宮永忠彦”、北鄉邦昭、

仁瓶善郎、三島好雄

従来の裹腫切除に加え、腹側膵切除により拡張腪管 を切除した莿管胆道合流異常症の一例を経験したので報 告する。症例は上腹部痛を主訴とする67歳女性で、急 性膵炎の診断で入院となった。ERCP検査で最大径 $35 \mathrm{~mm}$ の総胆管襄腫を認め、新古味分類のType III C3の 䐙管胆道合流異常症と診断した。手術は総胆管衰腫切除、 腹側䐙切除を施行した。事腫を䐙内まで剥離し、総肝管 の部位にて震腫を切離した。十二指腸第三部より腹側茦 を剥離、Wirsung管（以下W管）の十二指腸主乳頭への 流入部を結禁の後、さらに頭側で膵実質を切離し Santorini管 (以下S管) に流入するW管を結禁切離した。 再建は絵肝管十二指腸端側吻合を行った。術後6ヶ月の 現在、体重減少、耐糖能障害なく経過している。Type III C3の膵管胆道合流異常症では拡張した共通管を残す ことにより症状の改善が得られないこともあり、幽門輪 温存䐙頭十二指腸切除術が適応されることが報告されて いるが、縮小手術としての衰腫切除、腹側苇切除術は安 全に施行可能であり臓器温存、術後QOLの点で優れた術 式と考える。
I -283 総䏣管異所性膵組織の 1 例

仙台赤十字病院外科

中川国利、兒井律郎、豊島 隆、桃野 哲、

佐々木陽平

本邦 6 例目と思われる総䏣管異所性膵組織の 1 切除 例を経験したので、報告する。

症例は71歳の女性で、1987年 3 月心窝部痛を主訴と して来院した。最大径 $12 m \boldsymbol{m}$ と軽度の総䏣管拡張と䏣管 ・䏣襄管合流部の狭窄を認めた。なお膵管胆管合流異 常は認めなかった。症状が軽度なため経過観察すると、 1994年 6 月には径 $20 \mathrm{~mm}$ と総䏣管拡張は著明になった。 心窝部痛は次第に増強し、1995 年10月には総䏣管は径 $34 \mathrm{~mm}$ とさらに拡張した。そてで狭窄を伴ら総䏣管拡張 症として、手術を施行した。手術所見では総胆管は著 明に拡張し、䏣管・䏣囊管合流部に狭窄を認めた。䏣 道鏡検査では狭窄部に腫痬は認めなかったが、䏣汁中 アミラーゼ10330 IU とと高值であった。そてで総䏣管を 切除し、肝門空腸吻合術を行った。切除標本では䏣管 - 総䏣管合流部は全周性に肥厚し、とくに䏣囊管開口 部近傍が著明であった。組織学的には䏣囊管開口部近 傍の総䏣管壁外層に、 $4 \times 2 m m$ 大の膵組織が島状をなし て異所性にみられた。膵組織は腺房細胞、Langerhans 島、導管より構成されていた。

I -284 腹腔鏡下にて摘出し得た脾過誤腫の 1 症例

福岡大学医学部第二外科

四宮義浩、山下裕一、前川隆文、秀島 輝、酒井憲見、 衣笠哲史、吉武裕明、白日高歩

我々は比較的稀な脾過誤腫症例を経験し、腹腔鏡下 にて摘出し得たので報告する。症例は 55 歳男性。自 覚症状なく、町内検診の腹部超音波検査にて脾臓内腫 瘤を指摘され当院第一内科を受診した。腹部超音波検 査にて脾下極部に $2 \mathrm{~cm}$ 大の低エコー腫瘤を、腹部血管 造影検査にて同部に腫瘍濃染像を認めた。CT、MRI、 Gaシンチでは同腫瘤を描出できず、画像による質的診 断が困難なため切除目的で当科入転科となった。腫痬 は脾臓内に限局しており、脾腫大も認めなかったため 腹腔鏡下脾摘出術を選択した。脾臓は $12 \times 9 \times 2.5 \mathrm{~cm}$ 大で、表面は平滑で、明らかな腫瘍は触知されなかっ た。割面では $1.5 \mathrm{~cm}$ 大の薄茶色で被膜を伴わない充実 性腫瘍を認め、組織学的には脾過誤腫と診断された。 本症は稀な疾患で、画像診断についても特徵的な所見 に乏しく、摘出後に組織診断にて確定されることが多 い。しかし本症は一種の組織奇形で、大部分が孤立性 で、文献上悪性化の報告もないため、より侵襲が少な い術式が望まれる。従って、腹腔鏡下脾摘出術は本症 の選択術式の一つと考えられた。 
I - 285 脾原発悪性リンパ腫の 2 例

済生会今治病院外科

山本 修, 黒河達雄, 因藤春秋, 渡辺哲也,

買原彰彦, 森近俊彦

【症例 $1 】 46$ 歳男性. C型慢性肝炎で通院中に腹部工 コーで脾臓に $4.8 \mathrm{~cm}$ 大の低エコーの腫瘤を指摘された。 CTでは低濃度, MRIでは $\mathrm{T}_{1}$ 強調像, $\mathrm{T}_{2}$ 強調像ともにや や低信号であった. 他にリンパ節腫大を認めなかった. Gaシンチでは脾腫瘤に一致して集積像が認められた。 血管造影ではhypovascularであった. 脾原発悪性リン パ腫と診断し, 脾摘出術を施行した. 病理組織学的検 査の結果malignant lymphoma, non-Hodgkin, diffuse, medium-sized cell type (LSG 分類) であった.

【症例2】61歳男性. 下腹痛, 下痢, 下血症状で来院, 大腸内視鏡検査で虚血性大腸炎の所見を認め, 保存的 治㞠にて軽快した．腹部エコーで脾腫及び脾内の 5.0 $\mathrm{cm}$ 大の低エコーの腫瘤を指摘された. CTでは低濃度, MRIでは $T_{1}$ 強調像, $\mathrm{T}_{2}$ 強調像ともにやや低信号であっ た. Gaシンチでは脾腫瘤に集積像が認められた. 脾尾 - 脾合併切除術を施行した. 病理組織学的検査ではmalignant lymphoma, non-Hodgkin, diffuse, large ce11 type であった.【考察】脾原発悪性リンパ腫は非 常にまれであるがエコー, CT, MRI , 血管造影, Gaシ ンチの所見を総合し術前に診断することが出来た.

$\mathrm{I}-286$ 脾原発悪性リンパ腫の 1 例

三枝病院 ${ }^{11}$ 、千萧大学第一外科 ${ }^{2 !}$ 、最成病院 ${ }^{31}$

三枝奈芳紀 ${ }^{1}$ 、三枝一雄 ${ }^{11}$ 、布村正夫 ${ }^{21}$ 、小田继司 ${ }^{21}$ 塩崎哲三 ${ }^{31}$ 、菅野雅彦 ${ }^{31}$

脾原発覀性リンパ腫の 1 例を報告する。症例は 71 才の女性で、人間ドックにて脾腫癌を指摘された。体 表リンパ節は触知されなかったが、左季助部に腫大し た脾を触知し軽度の在痛を認めた。血液検查では軽度 貧血を認めたが、末梢血液像に異常は認めなかった。 腹部超音波検査、腹部 $\mathrm{C} T$ 検查では腫大した脾内の大 部分をしめる境界明瞭な腫痹を認めた。血管造影では 腫場部はhypovascularであった。消化管の検索では圧 排所見のみであり、胸部X線検查でも異常は認められ なかった。原発性脾腫瘍の診断で開腹術を施行した。 脾は中等度に腫大しており、表面は脾組織で覆われて いるものの凹凸不整で弾性硬であった。脾門リンパ節 を含めて脾摘出術を施行した。摘出脾は $12 \times 9 \times 8$ c m r゙重さは390 gであった。割面では黄白色結節 状の充実性腫場が認められた。病理所見では、L S G 分類のfollicular medium sized cell typeであった, また進行度はAhmann分類のstage 1 であった。腹部超音 波検査を施行するときにはこうした疾患も念頭におき、 脾に関しても慎重に検索を進めるべきである。
I -287胆囊摘出術後の不明熱で発見された結核性 脾膿瘍の 1 例

福島赤十字病院外科

伊勢一哉, 児山 新, 今野 修, 芳賀甚市

今回我々は胆襄摘出術後の不明熱で発見された結核 性脾膿瘍の 1 例を経験したので報告する。【症例】 5 4 歳女性。発熱出現し急性胆襄炎の診断にて手術目的 に入院。開腹下胆震摘出術を行い, 慢性胆囊炎の診断 を得た。経過は良好で, 術後 8 日目に $37{ }^{\circ} \mathrm{C}$ 台の熱が 出現, その後も熱発が続いた。諸検査において異常を 認めなっかたが，US，CTで術前に認めなかった脾 臓内多発性低エコー領域を認めた。原因は不明だが, 脾膿瘍を疑い抗生剂を投与したが，解熱せず，US・ C T で増大傾向見られ，多発性で抗生物質に反応しな い脾膿湯の診断で開腹, 脾荿摘出術を行った。脾葴内 に多発性の膿瘍が形成され，中心部は壊死しており， 膿瘍内容物の培養では細菌は同定できなっかた。H. E染色では細菌や真菌などは認めず, 一部の膿瘍周囲 に類上皮細胞やラングハンス巨細胞を認めたので，抗 酸菌染色を行い結核性類上皮性肉芽腫の診断を得た。

【まとめ】最近結核性疾患が増加しており，外科手術 前後においても，原因不明の発熱時には結核感染を念 頭においた検索が必要であると考えられた。

I -288 Expandable Metallic Stentの門脈内留置におうけ る実験的検郡一下大静脈及ひ腹部大動脈内留置との比較 北海道大学第二外科

宮崎恭介、西部俊哉、渡辺 智、北上英彦、鈴木 温 真名瀬博人、大柏秀樹、高橋利幸、加藤紘之

【目的】Expandable Metallic Stentの門脈内留置に関して stent留置期間を延長した場合と留固stent径を大きくした 場合の安全性を下大静脈、腹部大動脈内留置と比較した。 【方法】成犬を用い、A群: 門脈、下大静脈、腹部大 動脈にそれぞれ直径 $(\mathrm{mm}) 8 、 10 、 60$ modified Z-Stentを 4 週間留置しstent・血管比を1.1とした群 6 頭、B群：A群 の留置期間を 12 週にした群 2 頭、C群 : 門脈、下大静脈、 腹部大動脈にそれぞれ直径 $(\mathrm{mm}) 10 、 12 、 80$ stentを 4 週 間留置しstent血管比を1.4とした群 4 頭を作成した。評 価：開存の有無を確認し、組織学的検索を行った。

【結果】開存率は100\%であった。stentの埋没は各群で 差はなく門脈、下大静脈では中膜下端まで、腹部大動脈 では内膜内に留まった。門脈でのstent埋没部の中䐜平滑 筋層は三群間であまり変化ないのに対して、下大静脈で はA群に比してB、C群で肥厚し、特にB群の肥厚が著し かった。腹部大動脈でもA群に比してB、C群でstentを被 復する内䐜内に侵入する平滑筋層の肥厚を恋めた。

【結語】EMSの門脈内留置において血管壁に対する影 響が最も少なく、良好な修復治瘜を得ることができた。 
I -289 悪性門脈狭窟に対する Expandable metallic stent 留置

\section{愛媛大学第二外科}

渡部祐司、佐藤元通、上田重春、佐藤 尚、木村 茂 【目的】悪性門脈狭窄による門脈圧六進、肝障害を軽 滅するため、経皮経肝的または開腹下経回腸静脈的に門 脈狭窄部にExpandable metallic stent(EMS)を留置したので その安全性、有効性を検討し報告する。【症例】1.72歳 女性、肝門部胆管癌。肝門部で総肝管閉塞、門脈 $99 \%$ 狭 窄、肝動脈浸潤の他横行結腸浸潤もあり、術中肝門部照 射、門脈内EMS留置、結腸部分切除を施行した。回腸静 脈末梢枝より径 $10 \mathrm{~mm} 、 3$ 連のGianturco-Roesch Biliary Zstentを門脈内に留置し、門脈圧は150 $\mathrm{mmH}_{2} \mathrm{O}$ 低下した。2. 60 歳男性、中下部胆管癌。術中照射、胆道再建、消化管 再建を施行したが、術後ドレーンからの腹水を連日約 $700 \mathrm{ml}$ 認めたため、術後28日目に経皮経肝門脈穿刺に より径 $8 \mathrm{~mm} 、 2$ 連のGianturco-Roesch Z-stentを留置し、門 脈圧は $135 \mathrm{mmH}_{2} \mathrm{O}$ 低下した。留置翌日より腹水は隇少し た。【結語】異なったルートからのEMS 症例を経験し、 安全性、有効性を認めことから、今後門脈閉塞に対する オプションの一つになるものと考えられる。

\section{I - 290 比較的短期間に食道胃静脈瘤を呈した肝内}

門脈、上腸間膜静脈血栓症の一例

鐘紡記念病院外科、兵庫医大第二外科*

池田秀博、楠徳郎、森环磨、坂上庸一郎、昔田寛 ${ }^{*}$ 門脈系の血栓症は原因が確定できない場合も多く、 病態も血栓形成の部位亡程度により異なる。今回我々 は、肝内門脈、上腸間膜静脈血栓症により、短期間 に食道胃静脈瘤を呈し経時的に経過を観察し得た比 較的稀な症例を経験したので文献的考察を加え報告 する。症例は56歳男性。平成7年 1 月 $40^{\circ} \mathrm{C}$ の熱発、肝 機能障害のため近医入院精查。Fusobacteriumによる 菌血症と診断され、血管造影にて肝内門脈後枝、左 枝の閉塞を認めた。平成8年1月上部内視鏡検查にて 食道胃静脈瘤を認め入院となり、血管造影にて肝後 区域萎縮、肝内門脈狭窄、SMVから門脈本幹にかけ 閉塞、Cavernous transformation形成を認めた。肝生検 では門脈内の線維化亡小葉内に壊死性変化を見られ るのみであった。以上より、本症例の食道胃静脈瘤 は肝外門脈閉塞に起因する門脈圧元進が原因と考え られ、遠位脾腎静脈シャント(DSRS+PSD)術施行し た。化膿性門脈炎により肝外及び肝内門脈閉塞をき たし、その後比較的短期間Cavernous transformation及 び食道胃静脈瘤を形成した症例に対しDSRS+PSDを 施行し良好な経過を観察中の一例について報告する。
I - 291 門脈圧六進症における門脈逆流の臨床的 意義と治療についての検討

九州大学第2外科

川中博文、橋爪 誠、岸原文明、富川盛雅、 御江慎一郎、津川康治、田上和夫、杉町圭蔵

【目的】門脈逆流の予後との関連および治療について 検討した。【対象および方法】超音波ドプラ法を施行 した門六症244例を対象とし、門脈系の逆流例と非逆流 例で肝機能および予後を比較し、逆流例の治療につい て検討した。【結果】244例中 24 例 $(9.8 \%) に$ 門脈系の逆 流を認め、原因はArterio-portal shunt (A-P shunt)10例、 Budd-Chiari症侯群 (B-C)2例、Portal-systemic shunt (P-S shunt)12例であった。逆流例のChildスコアーは7.6 1.9 と非逆流例の $6.7 \pm 1.4$ と比べ不良であった。逆流例の3 年生存率は $24.9 \%$ と非逆流例の $68.7 \%$ に比べ有意に低 かった。多変量解析で有意な予後因子は肝癌、門脈逆 流、Alb、Bili rubin、腹水であり、門脈逆流は肝機能か ら独立した子後因子であった。脳症や食道胃静脈瘤の ある9例に対し治療を行なった。A-P shunt1例にTAEを、 P-S shunt8例に関しては、血行郭清術1例、シャント結 禁術1例、PTO 1例、B-RTO 5例施行した。全例で門脈 血流は順行性となり、脳症は消失し肝機能は有意に改 善した。【まとめ】門脈逆流例の予後は非常に悪く、 治療により肝機能や予後の改善の可能性が示唆された。

I - 292 肝硬変 ·門脈圧六進を伴わない門脈一大循 環短絡によるportal-systemic encephalopathyの 2 例

秋田大学第一外科

安藤秀明、浅沼義博、佐藤 勤、田中淳一、小山研二

【緒言】肝硬変症・門脈圧㠵進症を伴わない門脈一大 循環短絡を 2 例経験し、うち 1 例に対し開腹下短絡路塞 栓術を施行し良好な結果を得たのでこれを報告する。症 例 1】65歳男性 繰り返す意識障害あり投薬を受けていた。 血中アンモニア $165 \mu \mathrm{g} / \mathrm{dl}$ と異常を認め, 腹部超音波検査 および腹腔動脈造影で腹腔動脈根部から総肝動脈に至る 著明な拡張と A-Vシャント, 肝内血管は不整に拡張・屈 曲・蛇行していた。上腸間膜動脈造影門脈相では肝外 · 内門脈の著明拡張とP-Vシャントを認めた。肝内シャン トが大きくかつ無数にあり, 治療し得ず退院した。【症 例 $2 】 62$ 歳男性 アルコール依存症として治療を受けてい たが, 血中アンモニア $260 \mu \mathrm{g} / \mathrm{dl}$ と上昇認め、腹部超音波 及び血管造影で門脈腎静脈短絡を認めたやめ、開腹下経 回結腸静脈的および経大腿静脈的にカテーテルを誘導し シャントをRタノーで塞栓した. 術後血中アンモニアは $14 \mu \mathrm{g} / \mathrm{dl}$ となり， 3 年経過し症状を認めない.【まとめ】 長期にわたり繰り返す意識障害を呈していたP S S 症例 2 例を経験し， 1 例に対し開腹下経回結腸静脈塞栓を施 行し良好な結果を得た。 
I -293 Cavernous transformation を形成する悪 性肝外門脈閉塞症に対する手術

高知県立中央病院，外科

堀見忠司，公家健志，宮内章充，長田裕典，

西岡豊, 尾崎信三, 中城 徹, 松岡尚則,

中川仁志, 石井隆之

[目的］悪性疾患を原因とする門脈の cavernous transformation に対して，原疾患と門脈切除を可能と し，安全で確実な血行再建および消化管再建を施行す ることを目的として，種々の工夫を行ってきたので， 本会で報告する。 [対象と方法] 膵癌と胃癌に cavernous transformation を形成した肝外門脈閉塞症7例を経験 した。これらの内，1例の苹癌は非切除で, 門脈内に Wall stent を置いたが, 他の疾患は全て切除し得た。 術式は䐙頭十二指腸切除が 5 例で䐙全摘が 1 例に施行さ れた。これらの内，3例は上腸間膜静脈と羘静脈に体 外循環を設置した。また門脈の血行再建は，端々吻合 で再建できたが，2例は人工血管が使用された。［成績］ 7例中 1 例は肝不全で術死したが，他の6例は全て軽快 退院でき，QOLは著しく向上した。[結論] Cavernous transformation を形成した肝外門脈閉塞症に対して， 体外循環や人工血管など種々の工夫を駆使して根治的 に切除が可能となったので，その詳細を報告したい。

I - 294 肝門部胆管癌および膵頭部癌における門脈 合併切除術

都立墨東病院外科 ${ }^{1)}$, 同胸部心臓血管外科 ${ }^{21}$ 木村尚哉 ${ }^{11}$, 梅北信孝, 宮本幸雄, 真栄城剛,

山田福嗣, 粟根康行, 菅野隆彦 ${ }^{21}$, 田辺貞雄

[目的] 肝門部胆管および膵頭部癌の門脈浸潤例に 対する門脈合併切除，再建につき検討する。

[患者と方法] 48 才から 74 才までの 16 例（男性 9 例, 女性 7 例, 6 例が膵頭部癌, 10 例が肝門部胆 管癌）を 2 つ群に分類。A 群：（１３例）門脈再建 時, 門脈断端を端々吻合した群。 B 群：（３例）門脈 再建に自家静脈を間置した群。2 群間で門脈浸潤の距 離, 手術時間 - 門脈遮断時間, 出血量 - 輸血量, 術後 肝機能について比較した。なお, 門脈遮断時間が 20 分以上に及ぶ場合にはアンスロンチューブによる一時 的な門脈一門脈バイパスを造設し，1例については i n l a y s h u n t 施行し, 術中の肝虚血を予 防した。[結果] 門脈再建に要する時間は, A 群では 平均 20 分, B 群では平均 82 分であった。術後の血 液学的検査上, 2 群間に特異的な所見は認めなかった。 [結語] 術中の門脈血流維持は虚血による肝の障害を 予防し, 術後肝機能維持が図れ, 胆道系 - 膵頭部領域 の進行癌に対する拡大手術に貢献する。
I -295急性胆衰炎症例における経皮経肝胆衰ド レナージが腹腔鏡下胆衰摘出術に与える影響について 秋田県厚生連北秋中央病院外科 ${ }^{11}$, 秋田大学第 1 外科 ${ }^{21}$ 関 仁史 ${ }^{11}$, 上田 忠, 粕谷孝光, 小棚木 均 ${ }^{21}$ 【はしめに】胆共結石症による急性胆衰炎症例で術前 の経皮経肝胆衰ドレナーシ (PTGBD) の施行が, その後の 腹腔鏡下胆衰摘出術 (LC) に与える影響を検討した。

【対象と方法】過去2年間，当院で経験した胆裹結石症 による急性胆霍炎症例で, 術前PTGBD施行 5例と非施行 7例につき発症から手術までの期間，LC完遂の有無，手 術時間, 出血量, 術後合併症, 全入院期間を検討した。

【結果】PTGBD施行群では4例は発症から2日以内に，1 例は入院中悪化し17日目にPTGBDを行った。手術までの 期間はPTGBD施行群で17日目施行の!例を除き 28.8日， 非施行群19.8日だった。手術はPTGBD施行群は全例にLC が完遂できたが, 非施行群では3例でLCが完遂できたの みで, 他の4例は三管合流部の炎症が高度でLCを断念し 開腹の胆摘術に移行した。手術時間はLC完遂例では，PT $G B D$ 施行群1.8時間, 非施行群 2.0時間, 出血量は LC完遂 例では差はなかった。術後合併症は両群とも認めず, 全 入院期間はPTGBD施行群50.2日，非施行群45.0日だった。 【結語】急性胆褒炎症例では，発症早期の術前PTGBDは 胆衰および三管合流部の炎症の消退を促すことから保 存的療法に比べてしをを施行する上では有効と思われた。

I - 296 急性胆電炎に対する PTGBD挿入の意義 (Lap-Cを前提亡して)

大田原赤十字病院外科

村井信二, 雨宮 哲, 岡 昭一, 宮脇貴裕,

鵜野麻弓, 山口 博, 原 孝志, 赤松秀敏,

古泉桂四郎

【目的】急性胆囊炎に対し, PTGBD 挿入例は, LapCが容易であり，非挿入例では困難なことは第 47 回 消化器外科学会にて報告したが今回さらにPTGBDの挿 入時期においても胆囊頸部に炎症の差があることから 以下の検討を行った【【対象および方法】1995年 2 月 から1996年 2 月の 1 年間に当科のLap-C 症例は76例で あり，そのうち急性胆輬炎は17例であった。 PTGBD插 入例 14 例で，非挿入例は 3 例であった。手術法はLapCで開腹移行例はなかった。 PTGBD挿入例と非㨂入例 を手術時間, 胆囊管之胆襄動脈の処理法, 出血量, 術 後退院までの期間, 病理所見より検討しさらに挿入時 期による相違の有無を検討した。【結果】手術時間は 挿入例が平均 87 分, 非捙入例は平均 117 分あったが挿 入時期による差はなかった。PTGBD非挿入例では, 胆 串管胆蓑動脈の処理に対し, ENDO GIAの使用が必要で あった. 出血量, 術後在院期間に差はなかった. 病理 学的には, PTGBD を早い時期に挿入した症例ほど頸部 の炎症所見や線維化は軽度であった。 
I - 297 経皮経肝胆輬ドレナージ後, 腹腔鏡下胆 震摘出術を施行しえた症例におけるS I R S の検討

総合木沢記念病院 外科

伊藤英夫, 田辺博

【目的】 S I R S という概念が用いられるようにな った。ラパ胆において S I R S 症例を検討した。当院 では急性胆震炎にP T G B D を施行した後にラパ胆を 施行している.【対象】 P T G B D 後にラパ胆を施行 したのは 5 例である（GB D 群）。胆道造影にて胆囊 描出の陰性症例は 16 例であった（陰性群）。胆囊が 描出された症例 20 例 (描出群) とを比較検討した。 S I R S は診断基準を 2 項目以上を満たすときとした。 【成績】G B D 群のラパ胆前 S I R S 期間は平均 7.3日 であった。手術時には平均白血球数, CRPとも減少した。 P T G B D の期間は, S I R S の期間が長い症例ほど 長かった。術後 S I R S 期間は平均 3.6 日であった。陰 性群は, ラパ胆可能症例は術後 S I R S 期間は 1.5 日で あった。開腹移行例は術後のS I R S 期間は平均 3.4 日 であった。描出群は, 術後 S I R S 期間は0.6日であっ た、【結語】急性胆襄炎により S I R S となっている 症例は, P T G B D を施行し, S I R S 離脱後にラパ 胆を施行すれば，安全に手術できる. 胆裹描出陰性例 は開腹移行例で S I R S 期間が長く注意が必要である.

I - 298 選択的経皮経肝胆䨢穿刺造影とドレナー ジ81例の臨床的検討

富山市民病院外科

小西一朗, 上田順彦, 吉光 裕, 瀬川正孝, 太田長義, 角谷直孝, 広沢久史, 泉 良平, 広野禎介

くはじめに>過去 8 年間に経験した選択的経皮経肝胆 震穿刺造影（SPTC）51例とドレナージ（SPTCD） 31 例を対象として臨床的な有用性を検討した。

<成績 $>$ SPTCは胆石症 24 例、隆起性病変 8 例、胆震 炎 7 例、胆裹癌 4 例、その他 8 例に、SPTCDは急性 胆襄炎 22 例、その他 9 例に施行された。成功率は $100 \%$ 、合併症は 1 例のみであった。胆汁細胞診は 胆石11例、隆起性病変 8 例、胆囊癌 4 例（Stage I： 1 例）、その他 8 例に施行され正診率は $100 \%$ であっ た。胆汁培養は急性胆輬炎22例、胆石 16 例、その他 21 例に施行され、菌はそれぞれ16例、8 例、8 例に検 出された。菌種はE.coli 15 例、Kleb. 14例、Ent. 7 例、 Str. 3 例、その他 9 例で、複数菌感染が半数を占めた。 肝床部胆輬周囲膿瘍を合併した急性胆震炎22例に SPTCDを施行し、手術までの平均13日間に適切な抗 生郕を混じた生食水で胆襄内を洗浄することにより、 排膿が完了するとともに胆管像をえることができ、手 術は安全かつ容易に行えた。
I -299 DICを呈した急性閉塞性化脤性胆管炎に PTGBDが奏効した一症例

\section{関西労災病院 外科}

池倒均、植田 俊夫、河合 稳、近藤磁、

平尾 隆文、半田 節子、小合 裕司、今本 治度、

山崎 惠司、立周 寿比古、高塚 雄一

【はしめに】急性閉塞性化腿性胆管炎の治療方針は ます適切な胆道ドレナージを族行することにある。今 回我々はDICを呈した急性閉塞性化愲性胆管炎症例に 経皮経肝胆豆ドレナージ(PTGBD)を施行し良好な結果 を得たので、その症例を提示するとともに、PTGBD の有用性について若干の文献的考察を加元報告する。

【症例】患者は75才女性。平成7年8月5日、黄疸と 意識障害を现め緊急入院となった。血圧は64 $\mathrm{mmHg}$ 、 心拍数 120回/分、右侕腹部に圧痛あり。腹部CT上、胆

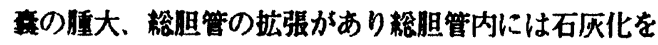

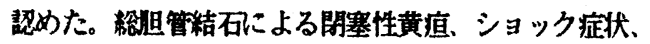
出血煩向を伴っていたため、急性閉塞性化脹性胆管炎 と診断し、第7病日PTGBDを施行した。胆汁は䝢性で 培義よりEc. faecalisが幙出された。ドレナージ開始後、 経過とともに全身状態は改書した。さらにPTGBDルー 卜を昖張し、第27病日より総胆管内に胆道鏡を㨉入し 総胆管結石の切石を關始し、第47病日終了した。

I - 300 Biliobiliary fistula に対し胆管節状切

除，胆管胆管端々吻合術を行った 1 例

名古屋市立大学第一外科

高山宗之, 橋本 俊, 真下啓二, 伊藤浩一, 福井拓治, 真辺忠夫

胆囊内結石症によるbiliobiliary fistulaに対する治療法 として, 胆管節状切除の後, 総肝管総胆管端々吻合に よる胆道再建術を施行し, 良好な結果を得た。

症例は57才の女性. 精査の結果, 胆襄内結石症, biliobiliary fistulaと診断され, 手術を施行した。

胆襄䅡部, 胆襄管, 瘦孔は一塊となっていた。胆管 粘膜を観察すると, ほほ全周性に内部粘膜に壊死性変 化が見られたためため, 胆管粘膜が健常な部位にて, 瘦孔，三管合流部を切除した。胆道再建は総肝管総胆 管端々吻合で行った。またTチューブを吻合部より末 梢側から挿入し, 肝臓側は 2 つに割り $\mathrm{Y}$ 字型として左 右それぞれの肝管に留置した。

術後は合併症もなく良好に経過した. 術後 28 日目 にTチューブを抜去し，32日目に退院となった。術後 178日目の 3 D - D I C - C T では吻合部の狭窄, 肝 内胆管の異常な拡張も認めていない.

胆管胆管吻合術，またbiliobiliary fistulaに対する治療 法について若干の文献的考察を加えて報告する. 
I一-301 特異な病態および形態を示した Biliobiliary fistula 2 例の手術経験

国立東静病院 外科

立山健一郎、尾関豊、片桐義文、小久保光治、

松原長樹、松尾浩、武井秀史、井上健、稲葉圭介

【目的】門脈前枝閉塞を伴い黄色肉芽腫性胆囊炎に合

併した胆囊総肝管瘦の症例と、門脈左枝閉塞を伴った

肝内結石症で右前枝肝内胆管と左肝管との間に内瘦を 形成した症例という極めて稀な 2 例について報告する。

【症例 1】72歳の男性。化膿性胆管炎で内視鏡的乳頭 切開、総胆管切石術後、胆囊癌を疑われ紹介。胆囊結 石と胆襄壁肥厚、門脈前枝閉塞を認め胆囊癌と診断。 肝右三区域切除、尾状葉切除術を施行。胆囊総肝管瘦 を認め病理で黄色肉芽腫性胆囊炎の診断であった。

【症例 2】58歳の男性。既往に胆摘および総胆管切石 術。発熱黄㾝で入院。総胆管・肝内結石を認め肝左葉 は萎縮して腫瘤様。門脈左枝は閉塞。総胆管・肝内結 石症に合併した肝内胆管癌を疑し肝左葉切除術、胆管 切除および右肝管空腸吻合術を施行。標本で前枝胆管 の結石が左肝管内に露出し内瘦を形成。悪性所見なし。

【結語】黄色肉芽腫性胆囊炎合併内胆汁漊や胆管同士 の内胆汁瘦の報告は他にない。炎症性変化および結石 による門脈閉塞と考えられ術前の癌との鑑別は困難で あり術中所見・迅速病理にて術式を決定すべきである。

I-302 Xanthogranulomatous cholecysititisに対 する手術術式の検討 一当科における67例の経験一

市立豊中病院外科、同病理*

新居延高宏、柴田高、高見元敞、过仲利政、高田俊明、 北田昌之、塚原康生、室谷昌弘、飯原啓介、塚本文音、 小川稔、木村正治、花田正人 $*$

【目的】今回、われわれは過去25年間に手術を施行 したXanthogranulomatous cholecysititis(XGC)67例に 対し手術術式の選択上の問題点や腹腔鏡下手術の適応 について検討した。【方法】1971年から1995年末まで 胆豪摘出術を施行した1945例中67例 $(3.4 \%)$ の XC を対象とした。【結果】開腹下胆毫摘出術は61例、腹 腔鏡下手術を6例に試みたが開腹移行は3例で、いずれ も病悩期間の長い慢性炎症型であった。合併切除は3 例に施行し肝部分切除 2 例、十二指腸部分切除、結腸 部分切除は各々1例であった。X G Cに4例 (6\%)の 胆素癌を合併した。術後合併症は9例で、創感染5例、 胆汁瘦 2 例、腹腔内膿谤、胸水貯溜を各々 1 例認めた。

【結論】X G Cの手術に際して術前、術中の病理組織 診による胆慗癌の除外が拡大手術を回避する上で重要 である。また腹腔鏡下手術は高度な疹着があることよ り慎重な剥離操作が必要で、特に病悩期間の長い慢性 炎症型には安易に選択すべきではないと考える。
I -303胆汁細胞診でC 1 a s s V ट診断され、胆 囊癌之鑑別困難であった黄色肉芽腫性胆襄炎の 1 例 徳島大学第一外科 ${ }^{1}$, 同病理 ${ }^{2}$

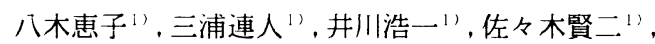
三瀬光太郎1)，石川正志"), 福田洋 1), 三宅秀則 ${ }^{12}$, 松村敏信 ${ }^{1)}$ 、田代征記")，佐野暢哉 ${ }^{2}$

黄色肉芽腫性胆囊炎 (Xanthogranulomatous cholec ystitis, 以下X C ）は比較的希な胆襄炎で、癌之の鑑 別が困難な疾患の 1 つさされている。今回、胆汁細胞 診でC 1 a s s V ट診断され、画像診断的にも癌亡診 断し手術したX Cの 1 例を経験したので報告する。 本症例は初診時急性胆裹炎を併発し、経皮経肝胆襄 ドレナージ（ＰＴＧＢＤ）を行った。胆汁細胞診で C 1 a s s V ट診断され、画像診断では胆襄壁は肥厚 し、肝との境界は一部不明瞭であった。ss胆襄癌と診断 $L 、 S_{4}$ a,$S_{5}$ 区域切除. 胆管切除, No16を含む $R_{2}$ リン パ節郭清を行った。切除標本の病理組織所見は、X C であった。胆裹粘膜には再生性の異型上皮は認めるも のの悪性所見はなかったが、免疫組織染色で散在性に p53陽性細胞が見られた。

以上より、胆囊癌の鑑別にX C を念頭に置くことが 必要である。またX C と胆裹癌の合併の報告もあり、 p53陽性細胞が散見された本症例は、malignant poten tialを有していた可能性があると考えられた。

I-304胆癌と鑑別困難であった Xanthogranulomatous cholecystitis $の$ 一例

和中央病院外科

j上热、增井俊彦、江下恒統、川口迎也、瓜生原

的同、佐野望、吉田泰夫、伊藤雅、記井英治、河野

裕、小笠原敬三、高三秀成

今回我々は胆衰癌と鑑別困難であった Xanthogranulomatous cholecystitis(以下 XGC) の一例を 経験したので、文献的考察を加えて報告する。【症 例】69歳、女性:。1994年7月5日、左乳癌で非定型的乳 房切断術施行。1995年8月に行った定期検査で胆襄に 病変を認め、精査目的で9月 5 日入院。腹部 CT、MRI で、胆菙内部に結石を認めるとともに胆囊体部に数 $\mathrm{cm}$ 大の全周㥩の腫瘤を認め、胆囊癌と肝への直接浸潤を 疑った。

1995年9月12日手術施行。胆襄は壁肥厚を認め内部に 絡石老触知した。肝床部の腫瘍は触診では不明瞭。周 朋への浸潤は明らかではなかった。胆潩摘出と肝床部

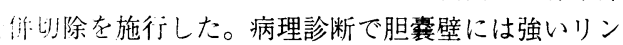

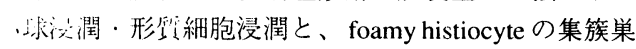

想らう、XGCと考えられた。【考察】XGCは、 胆囊壁内に肉芽腫を形成する比較的希な胆軎炎の一亜 型である。本症例のように急な経過をとる例もあり、 胆囊癌との鑑別に注意する必要がある。 
I -305気腫性胆囊炎の病態と治療

大泉記念病院外科松本純

(目的) 気腫性胆霊炎に於けるガス発生のメカニズム を解明するために最近経験した 2 例の症例を用いて胆汁 の組成と胆襄壁の病理組織検索を行った。

(症例) 症例 $1 ； 73$ 歳、男性. 前日昼頃より右季胁部 痛あり、白血球数 $18 、 100$. 入院後腹部単純X線及びCTで 上記診断となり、直ちにPTGBDを行った。黒褐色の胆汁 $70 \mathrm{ml}$ と悪臭持つガス $34 \mathrm{ml}$ 吸引した。胆汁の糖は $0 \mathrm{mg} / \mathrm{dl}$ で、培養では嫌気性グラム除性桿菌が証明された。摘出 した胆潩の壁は全層に壊死を認めた。

症例 $2 ; 68$ 歳、男性. 胆石症の手術 2 日前に突然の右季 肋部激痛と白血球数上昇あり．腹部CTで胆衰内にガス像 を認めた. PTGBDでは黒褐色の胆汁 $60 \mathrm{ml}$ を吸引、ガスは

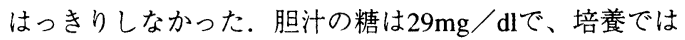
菌は証明されなかった。 2 日後に摘出した胆衰の壁は胆 衰底部だけが壊死を示した。

(考察) 気腫性胆裹炎は胆衰壁の壊死部から胆汁内に 流れ込んだ血漿の糖が細菌により分解されてガスを発生 するものと思われ、症例 1 では分解が進んで胆汁内糖が 証明されず、症例 2 では発生直後のため糖がまだ残って いたと推論された，気腫性胆雴炎の治療に当たっては壁 の壊死を伴っているので、直ちに胆襄内減圧を行い、時 期をおかずに手術を行うべきである.

\section{I一306遗残手術用䧿合針が核となった肝内結石} をPTCSによって摘出し得た 1 症例

姫路聖マリア病院外科 ${ }^{11}$ 、同放射線科 ${ }^{2)}$

大谷 順、河合 央、植村忠廣、菅 正人

丸山修一郎、吉䔈 憲、森末真八、唐土善郎

山本雅彦、曽田益弘 ${ }^{11}$ 、三村秀文 ${ }^{21}$

手術用の縫合針が核となった極めて稀な肝内結石の

1 症例を経験し、低侵襲下に摘出し得たので、若干の 文献的考察を加えて報告する。

【症例】患者は72歳、男性、既往歴として胃部分切 除、胆異摘出術を受けている。胆道精查目的で当科紹 介となったが、腹部単純 $\mathrm{X}$ 線写真で右上腹部に弓状 の異物を認め、超音波検査では肝内結石が疑われた。 PTCで左肝内胆管内に異物とそれを取り巻く透瞭像 を認め、胆石手術時の手術針を核とした肝内結石と診 断した。PTCS下に除去を試みたが、結石を直視出来 ず摘出不可能であった。そこで ESWLを併用するこ とにより、結石を破砕した後、再度 PTCSを行い、結 石、および異物を摘出することに成功した。摘出され た異物は手術用縫合針であり、胆石手術の際、遺残し た針が迷入して核となった胆石と思われた。

【考察】ESWLは、一般には肝内結石の破砕には使 用されないが、自験例の異物が核となった胆石の除去 においては有力な PTCS の併用療法となった。
I -30795歳、男性に発症した、自発性外胆汁瘦の一例

国立横浜東病院 外科 杉本克己 土屋博 佐野涉 十川康弘 雨宮邦彦

今回、我々は、胆囊胆石に合併して発症した、自発性（特発性） 外胆汁瘻を経験したので、若干の文献的考察とともに報告する。 症例は95歳、男性で主訴は、存側胸部腫瘤、疼痛であった。既 往歴としては、平成元年より、糖尿病、高血圧、胆異胆石、1 度 ないし 2 度房室ブロックのため当院内科で治療中であった。現病 歴及び経過だが、平成 6 年 9 月、3 个月程前より、右側胸部に腫 瘤が発生、しだいに増大、痛みを伴ってきたが、保存的に加療さ れていた。平成 7 年 4 月同部より膿流出、自潰してきたため当科 紹介となった。外来にて切開し排膿したところ難治性の胆汁瘦を 形成した。これに対し、瘦孔造影により確定診断を得たうえで、 局所麻酔下に瘦孔切除・ドレナージ術を施行、良好な結果を得た ものである。

自発性胆汁瘦は、胆道系が、高度な炎症や腫瘍浸潤により他臓 器と癒着、穿孔・穿通を起こして生じるもので、比較的稀な疾患 である。自発性胆汁瘦には内胆汁瘦と外胆汁湄が存在するが、頻

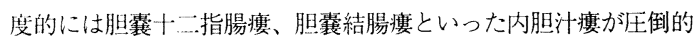
に多い。一-方、手術や外科的侵襲手技を伴うことのない、腹壁や 胸壁への穿通である自発性外胆汁瘦は、さらに少なく、本邦の文 献上でも30例を数えるのみである。文献的考察とともに報告する。

I -308 胆石症に対するthermal ablationの1例 東海記念病院 外科

平井一郎、林正修、野々山孝志、水谷隆

【日的】近年、胆囊結石症例に対し腹腔鏡下胆囊摘出 術が普及してきているが、全身状態により全身麻酔下 の手術が困難な場合がある。また経皮経肝的胆輁ドレ ナージ(PTGBD)ルートで砕石しても、粘膜が遺残し胆 不、胆囊炎の再発の危険性がある。そこで我々は局所 麻酔下で、PTGBDチューブから高熱の液体を注入する だけの簡便な方法である、胆囊thermal ablationを行い 良好な治療効果を得たので報告する。【症例】99歳、 女性。胆軎結石症による急性胆囊炎に対しPTGBDを行 つた。造影で胆囊管の閉塞、胆囊内結石陰影を 1 個認 めた。まず経皮経肝的に電気水圧衝撃波(EHL)で砕石し たのちに施行した。【方法】4\%キシロカインを胆輬内 に5分間注入し、麻酔した。沸騰した $50 \%$ ウログラフ イン $5 \mathrm{ml}$ をPTGBDチューブに数回注入し、胆囊内の温 度を上梨させ、最後の注入は2分間留置した。【成績】 thermal ablationにより胆霊内容量は $5 \mathrm{ml}$ から $1 \mathrm{ml}$ へ減少 し、PTGBDチューブを抜去することができた。また術 中に造影剂の胆囊外漏出、全身状態の変化、疼痛およ び術後出血は見られなかった。【結論】全身状態の不 主な胆不、胆囊炎症例では低侵襲な thermal ablationは 非常に份用である。 
I-309肝内胆管癌の臨床病理学的検討：

AgNORsによる悪性度の比較

大垣市民病院外科

金 祐鎬、山口晃弘、磯谷正敏、堀 明洋、 北川雄一、山口竜三、窪田智行、金澤英俊、松永和哉、 横山幸浩、小林 聡、

【目的】肝内胆管癌19例について臨床病理学的特徵か

ら分類し、進展様式と術式の選执について検討した。

【方法】4型に分類した。1) 胆管内乳頭型（IDP） : 3 例、2)胆管浸潤型（PDI）：4例、3)腫瘤形成胆管浸潤 型（MFI）：10例、4)腫瘤形成非浸潤型（MF）：2例。 切除例 13例についてAgNORsを計測した。【結果】肝

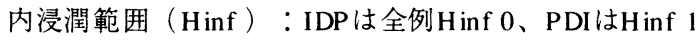
が2例、Hinf 3が2例、MFIは9例中8例がHinf 3、他の 1 例はHinf 2、MFはHinf 3であった。脈管侵襲・神経 周囲浸潤：MFI、PDIに認めたが、IDP、MFには認め ず。リンパ節転移：IDP、MFにはなく、PDIの1例、 MFIの9例中7例に認めた。切除断端陽性淬: IDP 1例、 PDI 3例、MFI 3例が陽性、MFは除性であった。

AgNORs : IDP ; 3.37、PDI ; 4.00、MFI ; 4.30、MF ; 3.91、各型間に有意差はないが、組織学的悪性度およ び予後とよく相関した。【結語】肝内胆管癌の術式は 上記の分類を考慮して決定すべきだが、PDIおよび MFIでは術前画像以上の胆管壁外進展がある。また、 AgNORs は予後因子として有用であると思われた。

I - 310 胆管細胞癌に対する超拡大肝切除の意義 山口大学第二外科

○高尾貴史, 西田峰勝, 前田義隆, 高尾康一郎,

清水良一, 岡 正朗,鈴木 做

【目的】胆管細胞癌は早期発見が困難で切除可能な症 例は肝細胞癌に比べ少ない。有効な内科的治療はなく 正常肝であることより、可能な限りの病巣切除が予後 改善への治療法となる。胆管細胞癌6症例に対し超拡 大肝切除を施行したので報告する。【対象】原発性肝 癌切除 180 例中、胆管細胞癌6症例(症例6の胆管䡒胞 腺癌1例を含む)を対象とし混合型肝癌3例は除外した。 【結果】男性2例、女性4例、年齢37～75歳。症例 1 : 体 外右 3 区域切除+下大静脈合併切除再建 + リンパ節郭清 (R2)。症例2:PTPE施行後、拡大肝右葉切除+脺頭十二 指腸切除+リンパ節郭清 $(R 2)$ 。症例 3 : 右 3 区域切除+右 尾状葉合併切除+リンパ節郭清(R3)。症例 $4: \mathrm{Vp} 3$ で拡 大肝左葉切除 + 左尾状葉合併切除 + 対側門脈内腫瘍栓 摘出術+リンパ節郭清(R2)。症例 5 :肝左葉切除+左尾状 葉合併切除+リンパ節郭清(R2)、症例6:肝左葉切除+リ ンパ節郭清 $(R 1)$ 。現在症例 1 : 術後 18 ヶ月で癌死、症例 4 : 術後6ヶ月で癌死。生存率は最長 36 ヶ月、中間値 15 ヶ月、1、3年生存率は83.3、41.7\%であった。

【結語】胆管細胞癌は可能な限りの病巣切除を行うこ とで予後改への道が開かれると考えられた。
I -311 小型の結節型胆管細胞癌切除例の検討

東京女子医科大学消化器外科

山本雅一, 高崎 健, 次田 正, 大坪毅人, 秋山和宏,

片桐 聡

【目的】小型の結節型胆管細胞癌切除例の臨床病理 学的な特徵について検討, 報告する。【方法, 成績】 対象は結節型胆管細胞癌切除例 32 例のうち $3 \mathrm{~cm}$ 以下 の 4 例（平均 $2.1 \mathrm{c} \mathrm{m}$ ) で、全例症状はなく，慢性肝 炎経過観察中に発見された４例中 3 例はHCV抗体 陽性であり，1例は肝炎ウィルスマーカーは陰性であっ た。腫瘍マーカーは 2 例でCA19-9，1例でCEAが軽 度上昇した。画像診断では全例肝細胞癌と診断された。 切除は部分切除が 1 例, 左葉外側区域切除が 2 例, 右 葉切除が 1例であり, リンパ節郭清はなされていない。 右葉切除後の 1 例は, 術後 1 年目に残肝再発に対し肝 再切除。その後肝十二指腸間膜部に巨大なリンパ節転 移再発を認め死亡した。その他の 3 例は全例, 術後 5 年以上生存中である。【結語】小型の結節型胆管細胞 癌は、慢性肝炎経過観察中に発見され、肝細胞癌との 鑑別は困難で、切除後の成績は良好であった。慢性肝 炎の経過観察により, 一部の結節型胆管細胞癌は早期 発見が可能と考えられた.

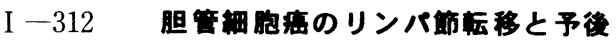

\section{京都大学第二外科}

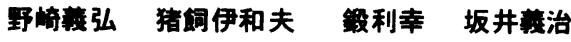
尾崎信弘山本雄造 山本正之山岡新生

【はじめに】胆管細胞且は、早期発見例が少なく、リ ンパ節枟移が多い。今回、肉眼分類、リンパ篎枟移と 予後の成速について模时した。【対象】当科にて遇去 10 年間に切除された 47 侧を対象とした。【結果】

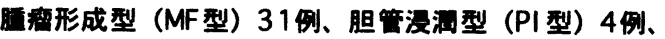

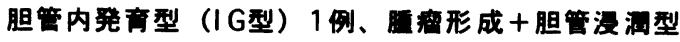
(MF+PI 型) 11 侧であった。UICCのT N M 分類では stage II 12 例、stage III 6侧、stageIVA 13 例、 stage IVB 16例であった。切除術式は 3 区域切除 11 例、2 区域切除 33 例、区域切除3例であった。3、5 生率はs tage II $(53.5,53.5 \%)$, st age III $(20,20 \%)$ 、stage IVA $(24.2,24.2 \%)$, stagelV

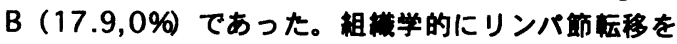
証明した16例は、MF型の6例 (19.4\%)、MF+PI型 の6例 (54.5\%)、PI型の4例全例 (100\%) で予後 不良であった。また、6例にNo.12（-）で志接 3 群以 上のリンパ節枟移ををたした例か现められた。

【まとめ】stage II 、リンパ節枟移のないMF型は予 後良好だか、予後改嚄のためには主腰存在部位、内 眼型を考虑したリンパ節郭湆方式の礁立が至まれる。 
I -313免疫組織化学的手法に上万胆管細胞癌切除症 例の検討 — regional heterogeneityを考虑した解析一

順天堂大学第 2 外科

高森 繁、吉本次郎、須郷広之、児島邦明、深澤正樹、 別府倫兄、二川俊二

【目的】胆管細胞癌(CCC)切除例について regional heterogeneityを考慮した免疫組織化学的検討を行う。

【対象・方法】バラフィン包埋標本を用い、腫瘍中心

部・先進部 $(\mathrm{n}=13)$ および転移部 $(\mathrm{n}=5)$ において、抗p53・

$\mathrm{Ki}$-67モノクローナル抗体(MAb)を用いた染色にて

Labeling Index(LI \%)を測定。同様に抗CEA ・CA19-9

MAbを用いて染色面積・局在様式を検討した。また、

核DNA量を測定しDNA ploidy patternを解析した。

【結果】p53およびKi-67 LIはともに先進部で有意に高 値を示した。また、先進部でのみp53 と Ki-67間に強い 相関を認めた。Ki-67高値群は有意に予後不良であった。 CEA, CA19-9染色では部位間で有意差を認めなかった が、CA19-9局在様式においてstromal typeは有意に予後 不良であった。 ploidy patternは部位間で差を認めなか つたが、転移陽性例は先進部で全例aneuploidであった。 【結語】p53,Ki67 LI, CA19-9局在様式およびDNA ploidy patternはCCCの予後因子となり得ると考えられ、 特に先准部における検討が肝要であると思われた。

\section{I -314高分化肝細胞癌切除例の臨床病理学的検討}

\section{大阪府立成人病センター外科}

中野博史、佐々木洋、今岡真舷、古河洋、石川治、 甲利幸、鲁山雅男、平塚正弘、大東弘明、中森正二、 安田卓司、岩永剛

【対象】1986年以後HCC切除453例中、前末治療 $3 \mathrm{~cm}$ 以下 106例で高分化(+)の62例を対象。全体高分 化33例(H)之周囲高分化内部中低分化29例(M)で比較。

【結果】1)背量因子 ICGはH21 1 8、M20 $49 \%$ LZ (+)はH75、M73\%(NS)。 $52:>2 \mathrm{~cm}$ は H22:11、M $11: 19(p<0.02)$ 。W(- ):(+)かH7:26、M13:16(NS)。 病理因子(+)\%はH:Mでfc 6:42、sf 15:61、vp 3:27。 im 3:11 で、Hが局所癌進展少数 $(p<0.02)$ 。2)治療成 績(\%) 切除後 3,5生率はH90,62、M85,66(NS)。切 除後 2,3年 DFSはHが 72,56、Mは 59,29(p<0.05)。 3)再発形式 再発3個以下:4個以上は、H12例で7:5、 M20例で 13:7(NS)。4)肝機能 とDFS ICG(20\%)別 2,3年DFS(\%)は、H:ICG良 (15例)が 78,70、ICG悪 (16例)か $68,43(\mathrm{p}=0.07) 、 M: I C G$ 良(16例)が86,49、 ICG悪(13例)が28,9(p<0.05)。【結語】高分化HCC の中で部分的に中低分化な成分を含む例は局所癌進展 因子の陽性率が高く術後DFSも不良。肝機能別にみる とMの中での肝機能不良群は良好群に比しDFSは不良。
$\mathrm{I}-315$

単発 $3 \mathrm{~cm}$ 以下肝細胞癌切除例の予後因子

の検討

大阪赤十字病院外科

有本 明, 中村 哲, 中島研郎, 吉田真規, 小角卓也 大江正二郎, 森田章夫, 山本俊二, 藤井一寿

中島康夫, 花房徹児, 浮草 実, 粟根弘治

【対象】1982 年より1995 年 8 月までに当科で 切除した肝細胞癌 178 例の内, 単発 $3 \mathrm{~cm}$ 以下 70 例 について検討した。【方法】各種因子が予後に及ぼす 影響をKaplan-Meier法を用いて比較検討した。

【結果】患者側因子としては, i mで有意差があった。 臨床病期 II は I に比し，C 型はB 型に比し予後不良の 傾向を認めた。 $\mathrm{f} \mathrm{c}, \mathrm{f} \mathrm{c}-\mathrm{i} \mathrm{nf}$, 分化度では有意 差がなかった。治療側因子では，有意差はなかったも ののTW(-)で予後良好な傾向があった。部分切除 vs

（覀区域十区域）切除, 出血量の大小で差はなかっ た。初回切除例亡再切除例に分けると, 再切除例の方 が有意に予後不良であった。 $\mathrm{im}(+)$, TW(+)の割合が再切 除例で高かったが, ICG 15分值，Thrombotest等背景 肝機能因子に差はなかった。切除後再発部位の検討で は同一覀区域 $24.1 \%$ ，隣接亜区域 $20.7 \%$ ，遠隔 $34.5 \%$, 全肝 multiple $20.7 \%$, 切除近傍にや や多い傾向を認めた。【結語】単発 $3 \mathrm{~cm}$ 以下例では TWの確保を優先した切除が望ましい。

\section{$\mathrm{I}-316$ 腫瘍径2 c m m下 の原発性肝細胞癌 に対する治療－手術がすべてか-}

国立呉病院、中国地方がんセンター外科 中場寛行,浜路政靖,長岡真希夫,中室誠,赤松大樹 盤井成光,金ヨウ国,白川圭俊,寺本成一,小牧孝充 $2 \mathrm{~cm}$ 以下肝癌 (HCC) 症例に対する治療法選択の 妥当性について検討を加えた。対象：主腫瘍が2 C m以下のHCC症例 38例（T128例、 $\mathbb{T} 2$ [衛星結 節十] 10例） USG : T125例が腫瘍の確認ができた。 T2では主董場は8例が磼認できたが衛星結節（S） は全例確認できなかった。血管造影：腫媓濃染は T124例に認められ、3例は判定不能であった。T 2の主腫場は全例濃染したが、Sが濃染したのは6 例であった。処置: 手術28例,TAE 6例,TAI 1例, PEIT 1例,無処置 3例であった。成績: 手術全例, TAE5例,PEIT1例は治癒と判定した。術前TAE4例 の病理所見では『11例完全壊死、1例90\%壊死、 T2 2例とも主腫湯は完全壊死したがSは生存して いた。まとめ: $2 \mathrm{c}$ m以下のHCCの術前検査の精度 は89\%を示し主腫場に対しTAEが有効であった。 従って、2 $\mathrm{c}$ m以下のHCCでは血管造影とTAEを行 い、T2であれば手術を選択し、T1であれば経過 観察し再発時適切な対応により手術と同等の効果が 得られると考えられた。 
東京女子医科大学付属消化器病センター外科

大坪毅人、次田 正、山本雅一、片桐 聡、秋山和宏、 高崎 健

【目的】肝細胞淂切除後の再発様式には多中心性再発 之転移性再発があるが、再発の危険因子はこの両者の 区別なく取り扱われている。そここで今回われわれは初 回切除時の病態と再発樣式について検討した。【対象 と方法】1989年〜1990年までに肝細胞癌に対し切除を おこなった症例のうち術後再発を認めた 84 例を対象と した. 再発巣に対し再切除あるいは肝生検で高分化型 肝細胞癌を認めたもの. あるいはアンギオエコーでne gaitve enhancementを認めた症例を多中心性再発、そ れ以外を転移性再発とした。これらの症例に対し、再 発様式別再発確認までの期間. 2) 初回切除時の進展因 子と再発様式の関係. 、肝硬変の程度と再発様式につ いて検討した.【結果】転移性再発は切除後 3 年以内 に再発を認めるのに対し多中心性再発は切除後 3 年を 経過しても散在性に再発を認めた.im2以上、vp1 以上 で転移性再発が多く、従来再発の危険因子として上げ られていた進展因子陽性は転移性再発の危険因子であ ことが明確となった。

\section{I -318 肝細胞癌外科切除例の予後規定因子に 基づく切除術式について}

新潟大学第一外科：塚田一博、若井俊文、青野高志、 黒崎 功、内田克之、白井良夫、畠山勝義

外科切除例の予後規定因子を明らかにし、肝癌に対 する切除方針を決定することを目的とした。【対象と 方法】過去約13年間に当科で切除された肝癌121例を対 象とし、臨床病理学的に検討した。検討因子は、肝癌 取り扱い規約に基づき各因子について単変量・多変量 解析した。生存率曲線はKaplan-meire法で求めLogrank 検定し、多変量解析はCoxの比例hazard modelを用いた。 【結果】(1)stage別 5 年生存率 : stage I $53 \%$ 、II $44 \%$ 、III 25\%、IV 35\%（有意差無し） (2)各因子毎の解析：肉眼型: 単結節型、組織型：well+mod、vp(-)、vv(-)、b(-)、s(-)、 $\operatorname{im}(-)$ 、大きさ $3 \mathrm{~cm}$ 以下、 $\mathrm{tw}(-)$ が予後良好な因子で生存率 曲線に有意差を認めた。(3)多変量解析：vp、vv、tw(-)が 予後規定因子であった。(4)tw因子 : tw(+)例ではvp陽性、 胆管浸潤陽性、浸潤性発育の癌が有意に多数をしめた。

【結論】肝癌肝切除例では、術式にかかわらず切離面 における癌浸潤の有無(tw)が予後規定因子であった。 胆管浸潤陽性癌、vp陽性癌、浸潤性発育癌のtwの判定 には細心の注意が必要で、tw(-)となるような術式を可 能な限り選択すべきである。
金沢医科大学一般消化器外科 北林一男、瀬島照弘、秋山高儀、富田富士夫、 斉藤人志、小坂健夫、喜多一郎、高島茂樹

【目的】肝細胞癌に対する姑息手術の要因を唡索する とともに切除例の治療成績から予後因子について検討 する。【対象と方法】肝細胞癌手術例 21 例を対象とし て、切除例と姑息手術例を比較検討する。切除例の治 療成績から予後因子について検討し、無再発生存例に ついても考察する。【結果】姑息手術例 $(\mathrm{n}=7)$ は切除例 $(n=14)$ に比較して、癌腫の大きさ、Stage求よび臨床病 期に有意差を認めた。肝予備能はICG15分值、K 值およ びR maxで有意差を認めた。切除例のうち在院死亡 3 例 は、いずれも術後出血による肝不全にて死亡した。絶 対的非治癒切除 2 例を除く 12 例の予後因子の検討では、 Stage、治癒度、臨床病期、Child 分類、術前TAEの有無 は予後に無関係であった。TW(-)の4 例のうち 3 例は生 存中で (1 例他病死)、TW(+)症例上りも有意に予後良好 であった。TW(+)症例は全例に残肝再発を認めた。無再 発生存例のうち最長例は 9 年であった。【結語】 1 、姑 息手術には癌腫の進行と肝予備能の低下の両者が関与 していた。2、切除例の予後には周術期の出血等による 肝不全の防止とTW(-)が重要であった。

I -320 切除後再発肝細胞癌症例の検討

\section{金沢大学第二外科 \\ 大西一朗、長谷部健、高村博之、山本精一、}

谷卓、橋本哲夫、清水康一、八木雅夫、宮崎逸夫 [目的] 肝細胞癌切除後再発症例において、生存率と 、再発形式、治療法等の諸因子との関連を検討した。

[対象] 絶対的非治痹切除々術死を除いた 145 例中、再 発の確認された103例を対象とした。[結果]再発時か らの生存期間（以下再発後生存期間）とStage ( $\mathrm{p}=0.04$ 45)、 $v \mathrm{p}(\mathrm{p}<0.0001) 、 \mathrm{vv}(\mathrm{p}=0.0207) 、 \mathrm{im}(\mathrm{p}<0.0001)$ と の関与が認められた。治療方法と再発後生存期間との 多変量解析では、肝動注化学療法 $(\mathrm{p}<0.0001) 、 \mathrm{TAE}(\mathrm{p}=$ $0.0311)$ 、と有意な関与を認めた。再切除 $(\mathrm{p}=0.0776)$ 、PEIT ( $p=0.0820)$ では関与寸る傾向を認めた。肝再発 形式と累積生存期間で有意な関与を認めた。病理形態 学的及び、経時的画像診断から異時性多中心性発癌上 推測されたのは11例であったが、他の群と比較して、 再発後生存期間、累積生存期間ともに、有意差は認め られなかった。[まとめ] vp, im等肝内転移の危険因子 の認められる症例で、再発後生存が不良であった。再 発後の肝切除、TAE、PEIT、肝動注が有効であった。多 発性肝再発症例の累積生存率は低いが、多中心発癌の 関与は不明で、今後の検討が必要と考えられた。 
$\mathrm{I}-321$ ポリアミン代謝からみたアルコール多

飲歴と肝細胞癌

大阪甫立大学第 2 外科

久保证一, 広橋 - 裕、由中宏、塚本忠司、

首藤太一大村 泰、木下博明

[目的］アルコール多飲歴と肝癌発生やその性質との 関係を検討するため、癌部および非癌部肝組織中のポ リアミン代謝を検討した。［対象と方法］対象は肝切 除施行朋癌 25 例で、これらをアルコール多飲 (A群) 9 例とアルコール非多飲（B群）16例に分類した。こ れら症例の癌部抢よび非癌部肝組織のオルニチン脱炭 酸酵素 $(\mathrm{ODC})$ 活性およびポリアミン濃传を測定した。 なお両群間の主腫瘍径に差はなかった。[絬果］A群 の癌部ODC活性は B 群のそれに比較し有意に高值であ った。またA群の非癌部ODC活性はB B群に比較し有意 に高值であった。 $\mathrm{A}$ 群の癌部および非癌部のPUTおよ びSPD濃度はB 群のそれらに比較し高值であった。ま た組織の増殖機転を示すPUT+SPD/spermineはB群に比 較しA群で有意に高值であった。［結論］ポリアミン 代謝からみて $\mathrm{A}$ 群の非癌部は B 群のそれに比較し発癌 ポテンシャルが高いと考えられた。また A 群の肝癌組 織はB 群のそれに比較し、増殖機転が盛んであると考 えられた。

\section{I -322 糖原病 I 型を合併した肝癌の 1 例}

\section{長野赤十字病院外科}

若林正夫, 花崎和弘, 袖山治嗣, 川村信之,

大塚満洲雄, 宮崎忠昭

糖原病 I 型は, glucose-6-phosphatase 欠損または 低下による，糖原の分解過程の異常を本態とする代謝 性疾患であり, 高尿酸血症や肝癌などの合併症が注目 されている。われわれは糖原病 I 型を合併した肝癌に 対し初回および再発に対して 2 回の切除を行なった症 例を経験したので報告する。

[症例] 40 才男性。平成 5 年 7 月より肝機能障害を 指摘され, 平成 6 年 3 月U S を施行したところ肝 $\mathrm{S}_{3}$ Vhypoecholic lesion を認め精查目的で入院， C T で肝 $\mathrm{S}_{3}$ V腫瘤を認め, 血管造影で同部に異常血管の増生 之濃染像を認めた。また空腹時血糖 $61 \mathrm{mg} / \mathrm{dl}$, 血中尿 酸 $10.5 \mathrm{mg} / \mathrm{dl}$, 肝生検組織の生化学検査で glucose 6-phosphataseの低下を認め, 糖原病 I 型に合併した 肝癌と診断し 7 月 14 日外側区域切除術を施行した。 平成 7 年 2 月腹部の手術創に腫瘤が出現, $\mathrm{C} T$ で肝 $\mathrm{S}_{7}$ 亿も腫瘤を認めたため肝癌再発として 6 月 15 日肝 $\mathrm{S}_{7}$ 部分切除, 腹壁腫溜切除, 大網および横行結腸部 分切除, 右副腎摘出術を施行した。現在外来にて経過 観察中であるが，再発の徴候はみられていない。

\section{I -323 大量消化管出血を契機に自然壊死したと 考えられる肝細胞癌の 1 例}

\author{
練馬総合病院外科 \\ 宇山一朗, 飯田修平, 荻原裕之, 高原哲也, \\ 早津成夫, 菊地嘉一郎
}

食道静脈瘤の破裂を契機に自然壊死したと考えられ る肝細胞癌の 1 例を経験したので報告する。患者 : 38 歳の男性。現病歴 : 大量吐血によるショック状態で入 院。内視鏡検査にて食道静脈瘤破裂之診断。入院時血 液検查成績 : $\mathrm{Hb} 6.2 \mathrm{~g} / \mathrm{d} \ell$, T-B $3.4 \mathrm{mg} / \mathrm{d} \ell$, AST $168 \mathrm{IU} /$ l. ALT $89 \mathrm{IU} / \ell$. AFP $23.6 \mathrm{ng} / \mathrm{m} \ell$. HBs $-\mathrm{Ag}(-)$, $\mathrm{HCV}(-)$ 。画像所見：入院12日目のCT検查では, 肝 S N に辺縁部のみが染まる低吸収領域を認めた。血管造影 椿查では腫瘍濃染像は認めなかった。肝動脈塞栓術や 抗癌剤注入などは施行しなかった。入院20日目のAFP 值は $4.5 \mathrm{ng} / \mathrm{m} \ell$ 之正常化していた。以上より肝細胞癌の 自然壊死と診断し, 手術を施行。病理検査 : 腫瘍は 1 cmの被膜に囲まれた結節状であった。被膜の内部は凝 固壊死に陥っており, 肝細胞の增殖が索状および腺腔 状に存在していたと考えられる所見があり, 肝細胞癌 であったと推定された。【結論】肝細胞癌の自然壊死 の機序として, 消化管出血による局所の虚血が関与し たと考えられる症例を経験したので報告した。

\section{I - 324 白血病化学療法中の肝 - 脾真菌性 搌瘍の治療について（2 例の経験から）}

徳島大学医学部第一外科

石橋広樹、嵩原裕夫、吉田金広、田代征記

【目的】我々は急性白血病化学療法中に発生した肝・ 脾真菌性膿瘍の 2 例を経験したので、その治療法につ いて文献的考察を加え報告する。

【症例 $1 】 12$ 歳で発症した急性前骨髄性白血病の男 児。化学療法後1力月頃から肝 - 脾多発真菌性膿瘍が 発生し、amphotericin B(AMPH)の静脈内投与を開始 した。肝膿瘍は消失したが、脾膿瘍は変化がみられず、 摘脾術を施行した。術後経過は良好で、化学療法を再 開できたが、約 1 年後に白血病の再発で死亡した。

【症例 2】17歳で発症した急性リンパ性白血病の男 児。化学療法後9力月頃に肝・脾多発真菌性膿瘍が発 生した。抗真菌剂投与で改善せず、摘脾術、肝生検、 門脈内力テ留置を行った。術後は、AMPHの全身およ び門脈内投与を行ったが、肝膿瘍は消失せず、肝動脈 リザーバー留置による動脈内投与を併用した結果、肝 膿瘍の消失した。今後化学療法を継続する予定である。

【考察】化学療法中の肝・脾の多発真菌性膿瘍の治 療法に関しては、摘脾術を併用したAMPHの門脈およ び動脈内投与が有効と考えられた。 
I -325肝癌術後難治性腹水に対しDenver Shunt を用いた腹腔体循環シャントが有効であった一例

久留米大学第二外科、*同第二内科

緒方俊郎、奥田康司、野口和典*、永嶋 潤、

今山裕康、木下壽文、中山和道、青柳成明

腹部外科手術後の難治性腹水は治療に苦慮することが 多く,原疾患に対する術後治療に対しても大きな妨げと なる。

我々は,肝硬变合併多発肝細胞癌に対し肝癌減量手術 を施行、術後肝動注療法を予定した。しかし、術後、 難治性腹水をきたし、OK432腹腔内投与,開腹下リンパ 管結紮術を試みるも無効で,最終的にDenver Shuntを用 いた腹腔体循環シャントを施行し,腹水の消失が得られ た。その後に有効な肝動注療法を施行し得、現在元気 に社会復鹵している症例を経験した。Denver shunt は チューブ内がヘパリンコーテイングされており、従来 のLeVeen Shuntと比較するとバルブの形状は閉塞しに くく、機能性も向上した。適応禁忌を十分に吟味すれ ば、合併症は少なく、 low costで比較的安全に難治性腹 水をコントロールできる。

原疾患治療の意味からも比較的積極的に考慮すべき 方法と考えられたので, 当学の腹腔体循環シャント術13 例の合併症、成績とともに報告する。

\section{I -326曹胞腺癌との金別に苦虑した衰胞性肝過誤 腫の 1 切除例}

柏市立柏病院外科 ${ }^{1)}$ 、同内科 ${ }^{2)}$ 、BML病理細胞診セン 夕ー ${ }^{3)}$

延澤進 ${ }^{1)}$ 、松本日洋、佐藤彰治、酒井英樹 ${ }^{2)}$ 、大林日 出雄、田中昇 ${ }^{3)}$

症例は 72 歳の女性で、当院整形外科外来で変形性脊椎 症の精査目的で施行された CT 検査で偶然に肝の襄胞性 病変を指摘された。隔壁に石灰化を伴い多房性のため、 内科で、超音波、腹部血管造影、囊胞穿刺細胞診、生検 を施行され、肝前下区域の衰胞腺癌の診断で外科に紹介 された。超音波では、隔壁に石灰化を伴う多房性の囊胞 の最大の房内に乳頭状隆起を示唆する所見を認め、造影 CT ではその造影効果は見られなかったが隔壁はわずか に増強した。超音波ガイド下穿刺内容液の CEA、CA199 は異常高值を示し、肝囊胞腺癌の診断のもとに拡大肝 右葉切除を施行したところ、囊胞内に結節はなく、泥状 のデブリスを含んでいた。病理組織検査で衰胞壁、肝門 側の胆管に悪性所見を認めず過誤腫の診断であった。肺 囊胞形成性腫瘍の質的診断はきわめて難しいが、その術 前診断について若干の文献的考察を加えて報告する。
I -327肝腫瘍に対する3次元CT肝アンジオグラ フィーの有用性の検討

岐阜大学大 2 外科 ${ }^{11}$, 同放射線科 ${ }^{21}$ 加藤元久 ${ }^{1)}$ 、佐治重豊、宮喜一、深田代造、梅本敬 夫、兼松雅之 ${ }^{2)}$ 、今枝孟義、星博昭

[目的]肝CT hepatic angiography (CTHA) 像より再構成 された 3 次元CT肝アンジオグラムの肝腫瘍に対する臨床 的有用性と限界について、血管造影像と比較検討した。 [対象および方法］肝腫瘍を疑われた 22 例 47 腫瘍を対象 とし、得られた 5 ミ厚ギャップなしの画像から、MIP 法および SSD法を用いて3次元CT肝アンジオグラムを作 成した。これらと血管造影像のmatched pairを外科医 と放射線科医による盲検法にて診断し、(1)肝門部およ び末梢動脈の描出、肝動脈全体の描出、(2)腫瘍の視認 性、（3）腫瘍部位の理解のし易さ、（4）栄養血管の描出 の 4 点について評価した。[結果] 肝動脈の描出は、血 管造影が優れていた。腫瘍の視認性および腫瘍部位の 理解のし易さは3次元画像が、栄養血管の描出は特にM IP画像が優れていた。腫瘍の描出率は、MIP、SSD、血 管造影でそれぞれ85、72、42\%であった。

[結語］肝CTA画像からMIP法にて構成された 3 次元CT肝 アンジオグラムは、肝腫瘍の視認性、局在、栄養血管 の描出において、通常の血管造影より優れていた。

I-328 3 次元画像 (3D CT) における肝静脈 の形態から見た肝切除後肝静脈再建の適応

横浜市立大学医学部 第二外科

志澤良一 渡会伸治 金村栄秀 仲野 明

関戸 仁 舛井秀宣 大木繁男 嶋田 紘

【目的】肝静脈の分岐形態を3D CTで明らかにし、肝切 除における肝静脈再建の必要性を考察した。

【対象】 Helical CTにてCTAPを施行した肝腫瘍21症例 【方法】肝内門脈・旰静脈の3D CTを作製し、左肝静脈、 中肝静脈、右肝静脈、右下肝静脈を各々 L、M、R、IR と 表記し肝静脈の分岐形態を検討した。肝静脈再建が必要 な肝切除症例は主幹肝静脈が合併切除され残存肝垔区域 のdrainage veinが失われる場合とした。

【結果】各亜区域のdrainage veinの形態は、(S2) L100\%, (S3) L100\%, (S4) M85.7\% L+M14.3\%, (S5) R23.8\% M19\% R+M57.2\%, (S6) R81\% IR4.7\% R+IR14.3\%, (S7) R90.4\% IR $4.8 \%$ R+IR4.8\%, (S8) R9.5\% R+M90.5\%であり、この 結果から右肝静脈を合併切除する $\mathrm{S} 7+\mathrm{S} 8$ 肝切除術で右肝 静脈再建の必要な症例は $90 \%$ 、中肝静脈を合併切除する 内側区域切除又は左葉切除で中肝静脈再建の必要な症例 は19\%であった。

【結語】 Helical CTによる3D CTを用いた肝静脈分岐形 態の把握は、肝静脈再建の必要性の診断に有用である。 
I -329 ポジトロンCTを用いた肝局所血液量測 定による肝腫場の鑑別部断について

\section{京都府立医科大学第一外科}

増山 守, 谷口弘毅, 小山拡史, 保島匡和, 田中宏樹, 麦谷達郎, 高田 敦, 高橋俊雄

【目的】今回我々はP E Tにて肝腫瘍の局所血液量を 定量的に測定し各腫瘍間で検討、肝腫瘍の鑑別診断が 可能かどうかにつき検討した。【対象】肝細胞癌：13 例 14 腫瘍（男：女 $=12: 1$ ）、胃癌肝転移：3 例 8 腫 瘍（男：女 $=3: 0$ )、大腸癌肝転移: 10 例 15 腫瘍（男： 女= 6:4）【方法】PETにて ${ }^{150}$ 吸入定常法により 肝腫瘍局所血液量を測定、同時に $\mathrm{H}_{2}{ }^{15} \mathrm{O}$ 静注動態法によ り肝腫場局所血流量及び組織血液分配係数を求め局所 血液量との相関を調べた。【結果】血液量の平均は次 の通りで、各群間に有意恙を喼めた。原発性肝癌 :

$15.1 \pm 1.11 \mathrm{~m}] / 100 \mathrm{~g}$ 、大腸癌肝転移 $: 11.2 \pm 0.93 \mathrm{~m} 1 / 100 \mathrm{~g}$ 、 胃癌肝転移：8.68 $0.28 \mathrm{ml} / 100 \mathrm{~g}$ (MEAN \pm SE)。腫瘍血 流量とは弱い相関しか認めなかった $(r=0.401 、 p$ $<0.05)$ が組織血液分配係数と強い相関を示した $(r=$ $0.731 、 \mathrm{p}<0.01 ） 【$ 考察】PETによる局所肝血液量 測定は現在の画像診断だけでは判別しにくい腫瘍の鑑 別診断の一助になると考えられ、肝腫場の全く新しい 鑑別診断手技となりうることを示唆すると考えられた。

I - 330 MTT assay によるヒト肝細胞癌臨床検体 における抗癌剤感受性について

\section{慶應義塾大学外科}

加藤悠太郎, 上田政和, 久保田哲朗, 松崎信二郎, 板野 理, 玉川英史, 富川盛啓, 池田信良, 隈元雄介, 唐橋 強, 若林 剛, 島津元秀, 北島政樹

（目的）抗癌剤感受性試験の一つであるMTT assayを 用いて, 肝細胞癌臨床検体の各種抗癌郕感受性を検討 した.（方法）1989年11月から 1995年12月までに当科 で切除された肝細胞癌症例のうち 81 例にMTT assay に よる抗癌剤感受性試験を行った。 判定可能例は65例 (80.2\%), 検討薬剂は, Adriamycin(ADM), Mitomycin-C (MMC), 5-FU, CDDP, SMANCS). 感受性は, 細胞增殖 抑制率 $50 \%$ 以上を陽性、30\% 49\%を比較的陽性、 $29 \%$ 以下を陰性とした（結果）65例中、ADM，MMC， $\mathrm{CDDP}$ と感受性陽性例は 5 例(7.7\%), 比較的陽性例は 4例(6.1\%), 陰性例は 56 例(86.2\%)であり，しかも，それ ぞれが同一症例であった. 5-FU感受性陽性例および 比較的陽性例はそれぞれ 1 例(1.5\%)，4例(6.1\%)であっ た. SMANCS感受性は，全例陰性であった（結語） 肝細胞癌の抗癌片感受性は低率であるが，陽性例では， 多郕に対して感受性を有していた。
I一331 ヒト肝細胞癌における microsatellite instabilityの解析

日本大学第 3 外科、同第 1 病理 ${ }^{1)}$ 、同第 2 病理 ${ }^{21}$

高木恵子、高野靖悟、加藤珠実 ${ }^{1)}$ 、江角真理子 ${ }^{1)}$ 、 関 訓芳、桧垣時夫、森口正倫、高橋知秀、伊藤 豊、 大石均、河野悟、佐藤一雄、山崎猛、川上新仁郎、 新槙 剛、中村正彦、三木敏生、横山武史、桜井 勇 ${ }^{2)}$ 、 岩井重富

(目的) 今回我々は、肝発癌とDNA修復機構の異常と の関与について、肝細胞癌で種々のmicrosatellite 領 域におけるRERの有無及びLOH について検討した。 (対象と方法) 原発性肝細胞癌38例を対象とし、癌部、 非癌部、血液よりDNAを抽出し、microsatellite領域 を含むDNAをPCR法にて增幅し、検討した。(成績) RERはACTBP2領域において4例(10.5\%)、AR領域に おいて1例認められた。（結語）1）ACTBP2を用いて RERを4例検出した。これより、ACTBP2領域が肝発 癌において不安定な領域であることが示唆され、ミス マッチ修復系遺伝子異常を知る補助診断として有用で あると思われた。2) 重複癌ではRERが高頻度に出現す ると報告されているが、多臓器重複肝細胞癌4例にお いてRER (-) であった。3)p53、Androgen receptor遺 伝子の欠損と肝発癌との関与が示唆された。

\section{I -332原発性肝癌における IGF2 遺伝子のゲノ ム刷り込みの回復について}

愛知県がんセンター研究所、超微形態 1)、同免疫 2 )、 同臨床検査部 3 ）、名古屋大学医学部第 2 外科 4 ）、 大垣市民病院消化器科 5 )

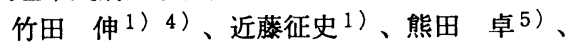

越川 卓 3 )、野浪敏明 4)、原田明生 4)、高橋利忠 2 )、 高木 弘4)、中尾昭公4)、高橋 隆 1)

ウイルムス腫瘍等の小坚腫場のみならず、肺癌等の 成人型腫瘍においても、発癌・進展にゲノム刷り込み が関与している可能性が最近示唆されている。今回、 我々は11p15領域に位置する insulin-like growth factor2（ IGF2 ) 遺伝子の Apa I 多型を利用して、原発性肝癌、 さらに前癌病変である肝硬変、慢性肝炎におけるゲノ ム刷り込みについて検討したので報告する。成人正常 肝においてはゲノム刷り込みが消失し biallelic な発現を みるのに対し、へテロ接合性を認めた原発性肝癌症例 15 例全例の癌部において monoallelic な発現がみられ、 ゲノム刷り込みが回復していた。興味深いことに、一 部の慢性非活動性肝炎、慢性活動性肝炎においてもゲ ノム刷り込みの回復が検出された。増殖因子を規定す る IGF2 遺伝子のゲノム刷り込みの変化が、肝癌の発 生、増殖に関連している可能性が示唆された。 
I -333 大腸癌肝転移症例の腫瘍ダブリン グタイムに関する検討

信州大学 第一外科

野村和彦、宮川畺一、原田晴久、北村宏、島田良、 小林聡、野池輝匡、川崎誠治

[目的］大腸癌肝転移症例の肝切除の適応について 肝転移巣の腫瘍ダブリングタイムを計測し検討した。

[対象と方法］1990年1月から1995年6月まで当科に おいて施行された大腸癌肝転移手術症例は50例であ り、うち22症例において肝転移巣の腫瘍ダブリング タイム（以下TDT）を計測することができた。TDTと 性別、年齢、原発部位、原発巣の分化度、腹膜播種 や腹腔内癌遺残の有無との関係について検討した。 [結果］TDTと年齢、性別、原発部位との間には明ら かな因果関係は認められなかった。しかし中分化型 腺癌のTDTは高分化型腺癌のTDTより有意に短かった。

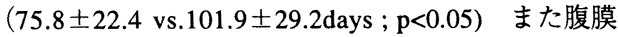

播種や腹腔内癌遺残を伴う症例のTDTは伴わないもの

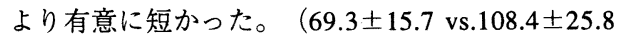
days ; $\mathrm{p}<0.01$ )

[考察] 肝転移巣の腫瘍ダブリングタイムの短い大 腸癌肝転移症例は腹膜播種や腹腔内癌遺残の可能性 がありそのような症例では充分な検索が必要と考え られた。

I -334 大腸癌肝転移切除例における残肝再発様 式の検討

奈良県立医科大学第一外科

大山孝雄、中島祥介、金廣裕道、久永倫聖、 青松幸雄、高 済峯、金 達也、八倉一晃、西尾和司、 庄 雅之、山田高嗣、中野博重

【はじめに】残肝再発をきたした大腸癌肝転移症例の 再発様式を検討した。【対象】過去 10 年間の大腸癌肝 転移切除例は55例で、残肝再発を24例に認めた。【結 果】1.初回肝転移部位および切除術式:1区域限局13例、 2区域5例、3区域以上6例であった。1区域限局のうち 外側区域4例は外側区域切除で、全例 2 区域以上に再発 した。他の9例はHr0;7例、 $\mathrm{HrS} ; 2$ 例で、同区域再発2例、 他区域7例であった。2区域5例は $\mathrm{Hr} 0 ; 1$ 例、 $\mathrm{HrS} ; 1$ 例、 $\mathrm{Hr} 2 ; 3$ 例で全例他区域に再発した。3区域以上6例は $\mathrm{Hr} 0$; 例、 $\mathrm{Hr} 1$;2例で他区域再発は2例であった。2.初回 転移個数:転移数 1 が9例、2が7例、3が2例、4以上が 6 例で、同区域再発は各々 2 例、0例、0例、4例、他区域 再発は7例、7例、2例、2例であった。3.生存率および 再発までの期間:同区域再発の平均生存期間は37ケ月 で、他区域再発は23ケ月であった。同区域再発の再発 までの期間は平均9.7ヶ月で、他区域再発は12.2ヶ月 であった。【まとめ】初回肝転移部位、肝転移個数、 肝切除術式、生存率、再発までの期間と再発様式に関 連は認めず、再発には種々の要素の関与が示唆された。
I -335 残肝再発に対し肝再切除を行った大腸癌 肝転移症例の検討

北九州市立医療センタ一 外科

阿部祐治、西原一善、岩下俊光、中原昌作、

勝本富土夫、黑川喜勝、武田成彰、安部隆二

[目的] 大腸癌肝転移に対する肝切除後の残肝再発 に対する、肝再切除の成績を検討する。

[対象と方法] 1986年から1995年までに当科で切除 した大腸癌肝転移51例(同時性26例、異時性25例)を対象 とした。このうち肝再切除を行ったのは6例(A群)でい ずれも初回が同時性であったので、同時期(1993年まで) の同時性一回肝切除症例13例(B群) と比較検討を行った。

[結果] $1 \cdot 2 \cdot 3$ 年生存率は、A群 $100 \cdot 83 \cdot 83 \% 、 B$ 群 84 .

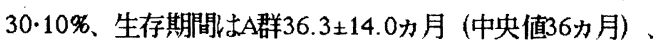
$\mathrm{B}$ 群20.5土14.3力月 (中央值16力月) とA群で有意に良好。 初回手術のH因子では、H1·H2·H3でA群 $2 \cdot 2 \cdot 2$ 例、B群 $7 \cdot 2 \cdot 4$ 例と同等であるが、最大腫瘍径はA群 $2.9 \pm 2.0 \mathrm{~cm}$ 、 $\mathrm{B}$ 群 $5.0 \pm 1.8 \mathrm{~cm}$ とB群で有意に大きかった。原発笨の病理 組織では、A群で全例が高分化、B群で高分化 $38 \%$ と分 化度のみで有意差を示した。初回切除より残肝再発診 断までの期間は、A・B群間でほほ差はなかったが、B群 では多発肝再発や早期の肝外再発が多かった。

[結論] 残肝再発例でも、症例を選んで積極的に再 切除を行えば、長期予後が期待できると考えられる。

I -336 大腸癌肝転移切除における肝内微小転移 巣の臨床病理学的意義について

防衛医科大学校第 1 外科

村山道典、初瀬一夫、長谷和生、柿原稔、青木秀樹、 重政有、大渕康弘、井戸田望、岩本一亜、望月英隆、 玉熊正悦

【目的】大腸癌肝転移切除における肝内微小転移巣の 意義を知る目的で臨床病理学的側面より検討した。対 象と方法】大腸癌肝転移切除 51 例を対象として、微小 転移巣の認められた 20 例(A 群)と認められなかった 31 例(B 群)を比較検討した。【結果】転移時期(同時性: 異時性);A 群(11:9)、B 群(14:17)、肝転移巣個数(単発:多 発); $\mathrm{A}$ 群(10:10)、B 群(18:13)、転移巣最大径; $\mathrm{A}$ 群 $4.1 \pm$ $2.0 \mathrm{~cm} 、 B$ 群 $4.0 \pm 2.8 \mathrm{~cm}$ でいずれも差はなかった。再発 率; $A$ 群 10/20=50\%、B 群 20/31=65\%で B 群が高い傾向 であった。再発部位は両群間で差がなかった。再発まで の期間;A 群 334 247 日、B 群 611 2287 日で A 群が短 かった $(\mathrm{p}<0.01)$ 。無再発生存率(1 年:2 年:3 年);A 群 (60\%:43\%:34\%)、B群(86\%:43\%:19\%)で差はなかった。 生存率(1 年:2 年:3 年);A 群 (88\%:73\%:50\%)、B 群 (96\%:84\%:59\%)で差はなかった。【考察】大腸癌肝転 移切除で肝内微小転移が認められた群は認められなか った群と比較として有意に再発が早く、睡瘍の悪性度 の指標になると考えられた。 
東海病院外科"，名古屋大学第一外科 ${ }^{2)}$

山本英夫 ${ }^{1,2)}$, 二村雄次 ${ }^{2}$, 早川直和 ${ }^{1,22}$, 神谷順一 ${ }^{22}$, 近藤 哲" ${ }^{2}$, 梛野正人 ${ }^{21}$, 金井道夫 ${ }^{22}$, 宮地正彦 ${ }^{21}$ 川端康次"，浜口 桂"

【対象】教室で経験した大腸癌肝転移切除例45例 （異時性26例、同時性19例）を対象とした。

【肝切除術式】初回肝切除術式は部分切除19例、区 域切除10例、葉切除16例であった。尾状葉の単独転移 例 $(\mathrm{n}=2)$ に対しては尾状葉単独切除・下大静脈合併切除 を行った。残肝再発に対して再肝切除を行ったのは5 例（部分切除2例、区域切除3例）であった。

【結果】在院死亡は術後7日目に急性心不全で死亡 した1例のみであった。全体の術後生存率は 1 年 $80.9 \%$ 、 3 年 $39.6 \% 、 5$ 年 $17.7 \%$ であった。再肝切除例のうち 3 例 は初回肝切除34、34、52力月後に再発死したが、2例 は初回肝切除後14、90力月の現在生存中である。尾状 葉単独切除後の予後は、1例は34力月後に肝再発死、 他の1例は26力月後の現在再発兆候なく生存中である。

【結語】1)残肝再発といえども術前の正確な診断の もとに積極的に肝切除を行うべきである。2)尾状葉転 移例は下大静脈切除を伴う尾状葉単独切除で良好な予 後が得られた。 